Louisiana State University

LSU Digital Commons

$1-1-2020$

\title{
Large-scale mass wasting on the miocene continental margin of Western India
}

\author{
Sarah K. Dailey \\ Louisiana State University \\ Peter D. Clift \\ Louisiana State University \\ Denise K. Kulhanek \\ Texas A\&M University \\ Jerzy Blusztajn \\ Woods Hole Oceanographic Institution \\ Claire M. Routledge \\ University College London
}

See next page for additional authors

Follow this and additional works at: https://digitalcommons.Isu.edu/geo_pubs

\section{Recommended Citation}

Dailey, S., Clift, P., Kulhanek, D., Blusztajn, J., Routledge, C., Calvès, G., O'Sullivan, P., Jonell, T., Pandey, D., Andò, S., Coletti, G., Zhou, P., Li, Y., Neubeck, N., Bendle, J., Aharonovich, S., Griffith, E., Gurumurthy, G., Hahn, A., Iwai, M., Khim, B., Kumar, A., Kumar, A., Liddy, H., Lu, H., Lyle, M., Mishra, R., Radhakrishna, T., Saraswat, R., Saxena, R., Scardia, G., Sharma, G., \& Singh, A. (2020). Large-scale mass wasting on the miocene continental margin of Western India. Bulletin of the Geological Society of America, 132 (1-2), 85-112. https://doi.org/10.1130/B35158.1

This Article is brought to you for free and open access by the Department of Geology and Geophysics at LSU Digital Commons. It has been accepted for inclusion in Faculty Publications by an authorized administrator of LSU Digital Commons. For more information, please contact ir@lsu.edu. 


\section{Authors}

Sarah K. Dailey, Peter D. Clift, Denise K. Kulhanek, Jerzy Blusztajn, Claire M. Routledge, GérÔme Calvès, Paul O'Sullivan, Tara N. Jonell, Dhananjai K. Pandey, Sergio Andò, Giovanni Coletti, Peng Zhou, Yuting Li, Nikki E. Neubeck, James A.P. Bendle, Sophia Aharonovich, Elizabeth M. Griffith, Gundiga P. Gurumurthy, Annette Hahn, Masao Iwai, Boo Keun Khim, Anil Kumar, A. Ganesh Kumar, Hannah M. Liddy, Huayu Lu, Mitchell W. Lyle, Ravi Mishra, Tallavajhala Radhakrishna, Rajeev Saraswat, Rakesh Saxena, Giancarlo Scardia, Girish K. Sharma, and Arun D. Singh 


\section{UC San Diego}

\section{UC San Diego Previously Published Works}

\section{Title}

Large-scale mass wasting on the Miocene continental margin of western India

Permalink

https://escholarship.org/uc/item/7174d6xp

Journal

GEOLOGICAL SOCIETY OF AMERICA BULLETIN, 132(1-2)

ISSN

0016-7606

Authors

Dailey, Sarah K

Clift, Peter D

Kulhanek, Denise K

et al.

Publication Date

2020

DOI

10.1130/B35158.1

Peer reviewed 


\title{
$a$ THE GEOLOGICAL SOCIETY BULLETIN

\section{Large-scale Mass Wasting on the Miocene Continental Margin of Western India}

\author{
Tracking no: $\mathrm{B} 35158$
}

\section{Authors:}

Sarah Dailey (Louisiana State University), Peter Clift (Louisiana State University), Denise Kulhanek, Jerzy Blusztajn (WHOI), Claire Routledge (University College), Gérôme Calvès (Universite Toulouse III Paul Sabatier), Paul O'Sullivan (Geosep Services), Tara Jonell (University of Queensland), Dhananjai K Pandey, Sergio Ando (Universita degli Studi di Milano-Bicocca Dipartimento di Scienze dell'Ambiente e del Territorio e di Scienze della Terra), Giovanni Coletti (Universita degli Studi di Milano-Bicocca Dipartimento di Scienze dell'Ambiente e del Territorio e di Scienze della Terra), Peng Zhou (Louisiana State University), Yuting Li (Purdue University), Nikki Neubeck (Louisiana State University), James Bendle, Sophia Bratenkov (Macquarie University), Elizabeth Griffith (Ohio State University), Gundiga Gurumurthy (Manipal University), Annette Hahn (Bremen University), Masao Iwai (Kochi University), Boo-Keun Khim (Pusan National University), Anil Kumar (Wadia Institute of Himalayan Geology), A. Ganesh Kumar (National Institute of Ocean Technology), Hannah Liddy (Columbia University), Huayu Lu (Nanjing University), Mitchell Lyle (Oregon State University), Ravi Mishra (National Centre for Antarctic and Ocean Research), Tallavajhala Radhakrishna (Centre for Earth Science Studies), Rajeev Saraswat (National Institute of Oceanography), Rakesh Saxena (ONGC), Giancarlo Scardia (Universidade de São Paulo), Girish Sharma (Kumaun University), Arun Singh (Banaras Hindu University), Stephan Steinke (Department of Geological Oceanography), Kenta Suzuki (Hokkaido University), Lisa Tauxe, Manish Tiwari (National Centre for Antarctic and Ocean Research), Zhaokai Xu (Institute of Oceanology, Chinese Academy of Sciences), and Zhaojie Yu (University of Paris XI)

\begin{abstract}
:
A giant mass transport complex was recently discovered in the eastern Arabian Sea, exceeding in volume all but one other known complex on passive margins worldwide. The complex, named the Nataraja Slide, was drilled by International Ocean Discovery Program (IODP) Expedition 355 in two locations where it is 300 $\mathrm{m}$ (Site U1456) and 200 m thick (Site U1457). The top of this mass transport complex is defined by the presence of both reworked microfossil assemblages and deformation structures, such as folding and faulting. The deposit consists of two main phases of mass wasting, each which consists of smaller pulses, with generally fining-upward cycles, all emplaced just prior to 10.8 Ma. The base of the deposit at each site is composed largely of matrix-supported carbonate breccia that is interpreted as the product of debris flows. In the first phase, these breccias alternate with well-sorted calcarenites deposited from a high energy current, coherent limestone blocks that are derived directly from the Indian continental margin, and a few clastic mudstone beds. In the second phase, at the top of the deposit, muddy turbidites dominate and become increasingly more siliciclastic. At Site U1456, where both phases are seen, a $20 \mathrm{~m}$ section of hemipelagic mudstone is present, overlain by a $40 \mathrm{~m}$ thick section of calcarenite and slumped interbedded mud and siltstone. Bulk sediment geochemistry, heavy- mineral analysis, clay mineralogy, isotope geochemistry, and detrital zircon U-Pb ages constrain the provenance of the clastic, muddy material to being reworked Indus-derived sediment, with input from western Indian rivers (e.g., Narmada and Tapti Rivers), and some material from the Deccan Traps. The carbonate blocks found within the breccias are shallow-water limestones from the outer western Indian continental shelf that was oversteepened from enhanced clastic sediment delivery during the mid-Miocene. The final emplacement of the material was likely related to seismicity as there are modern analogues for intraplate earthquakes close to the source of the slide. Although we hypothesize this area is at low risk for future mass wasting events, it should be noted that other oversteepened continental margins around the world could be at risk for mass failure as large as the Nataraja Slide.
\end{abstract}


India

4 Sarah K. Dailey ${ }^{1}$, Peter D. Clift ${ }^{1}$, Denise K. Kulhanek ${ }^{2}$, Jerzy Blusztajn ${ }^{3}$, Claire M. Routledge ${ }^{4}$,

5 Gérôme Calvès ${ }^{5}$, Paul O’Sullivan ${ }^{6}$, Tara N. Jonel1 ${ }^{7}$, Dhananjai K. Pandey ${ }^{8}$, Sergio Andò ${ }^{9}$,

6 Giovanni Coletti ${ }^{9}$, Peng Zhou ${ }^{1}$, Yuting Li $^{1}$, Nikki E. Neubeck ${ }^{1}$, James A.P. Bendle ${ }^{10}$, Sophia

7 Bratenkov $^{11}$, Elizabeth M. Griffith ${ }^{12}$, Gundiga P. Gurumurthy ${ }^{13}$, Annette Hahn ${ }^{14}$, Masao Iwai ${ }^{15}$,

8 Boo-Keun $\mathrm{Khim}^{16}$, Anil Kumar ${ }^{17}$, A. Ganesh Kumar ${ }^{18}$, Hannah M. Liddy ${ }^{19}$, Huayu Lu$^{20}$,

9 Mitchell W. Lyle ${ }^{21}$, Ravi Mishra ${ }^{8}$, Tallavajhala Radhakrishna ${ }^{22}$, Rajeev Saraswat ${ }^{23}$, Rakesh

10 Saxena $^{24}$, Giancarlo Scardia ${ }^{25}$, Girish K. Sharma ${ }^{26}$, Arun D. Singh ${ }^{27}$, Stephan Steinke ${ }^{28}$, Kenta

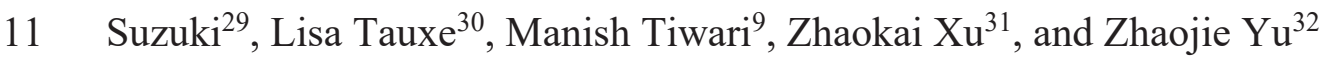

131 - Department of Geology and Geophysics, Louisiana State University, E253 Howe-Russell-Kniffen

14 Geoscience Complex, Baton Rouge LA 70803, USA

152 - International Ocean Discovery Program, Texas A\&M University, 1000 Discovery Drive, College

16 Station, TX 77845 , USA

173 - Department of Geology and Geophysics, Woods Hole Oceanographic Institution, Woods Hole, MA

18 02543, USA

194 - Department of Earth Sciences, University College London, Gower Street, London, WC1E 6BT,

20 United Kingdom

215 - Université Toulouse 3, Paul Sabatier, Géosciences Environnement Toulouse, 14 avenue Edouard

22 Belin, 31400, Toulouse, France

236 - GeoSep Services, 1521 Pine Cone Road, Moscow, Idaho 83843 USA

247 - School of Earth and Environmental Sciences, University of Queensland, QLD 4072, Australia

258 - National Centre for Antarctic and Ocean Research (NCAOR), Vasco da Gama, Goa 403804, India

269 - Department of Earth and Environmental Sciences, University of Milano Bicocca, Piazza della Scienza

27 4, 20126 Milan, Italy

2810 - School of Geography, Earth and Environmental Sciences, University of Birmingham, Edgbaston,

29 Birmingham B15 2TT, United Kingdom

3011 - Department of Earth and Planetary Sciences, Macquarie University, 202/1 Botany Rd., Sydney

31 NSW 2017, Australia 
3212 - School of Earth Sciences, Ohio State University, 275 Mendenhall Lab, 25 South Oval Mall,

33 Columbus $\mathrm{OH}, 43210$, USA

3413 - Manipal Centre for Natural Sciences, Manipal University, Manipal 576104, India

3514 - MARUM, University of Bremen, Leobener Strasse, Bremen 28359, Germany

3615 - Department of Natural Environmental Science, Kochi University, 2-5-1 Akebono-cho, Kochi 780-

378520 , Japan

3816 - Division of Earth Environmental System, Pusan National University, Jangjeon-dong, Geumjeong-

39 gu, Busan 609-73, Korea

4017 - Department of Science and Technology Wadia Institute of Himalayan Geology, 33 GMS Road,

41 Dehradun, Uttrakhand 248001, India

4218 - Marine Biotechnology Department, National Institute of Ocean Technology, Velachery-Tambaram

43 Main Road, Pallikaranai, Chennai 600100, India

4419 - The Earth Institute, Columbia University, Hogan Hall, 2910 Broadway, Level A, New York NY

4510025 , USA

4620 - School of Geographical and Oceanographical Sciences, Nanjing University, 163 Xianlin Avenue,

47 Nanjing 210023, P.R. China

4821 - College of Earth, Ocean and Atmospheric Sciences, Oregon State University, 104 CEOAS

49 Administration Building, Corvallis OR 97331, USA

5022 - Geosciences Division, National Centre for Earth Science Studies, Aakkulam Trivandrum 695031,

51 India

5223 - Geological Oceanography Division, National Institute of Oceanography, Dona Paula, Goa 403004, 53 India

5424 - ONGC, 11 High, Bandra-Sion Link Road, Mumbai 400017, India

5525 - Instituto de Geociências e Ciências Exatas, Universidade Estadual Paulista, 1515 Avenida 24-A, Rio

56 Claro SP 13506-900, Brazil

5726 - Department of Geology, Kumaun University, Nainital 263002, India

5827 - Department of Geology, Banaras Hindu University, Varanasi Uttar Pradesh 221005, India

5928 - Department of Geological Oceanography and State Key Laboratory of Marine Environmental

60 Science, Xiamen University, Xiamen 361102, P.R. China

6129 - Graduate School of Environmental Science, Hokkaido University, N10W5, Kita-ku, Sapporo 060-

62 0810, Japan

6330 - Scripps Institution of Oceanography, 9500 Gilman Drive, La Jolla CA 92093-0220, USA

6431 - Key Laboratory of Marine Geology and Environment, Institute of Oceanology, Chinese Academy of

65 Sciences, 7 Nanhai Road, Qingdao Shandong 266071, P.R. China

6632 - University of Paris XI (Orsay), Bâtiment 504, Orsay Cedex 91405, France

67

68 
A giant mass-transport complex was recently discovered in the eastern Arabian Sea,

71 exceeding in volume all but one other known complex on passive margins worldwide. The

72 complex, named the Nataraja Slide, was drilled by International Ocean Discovery Program

73 (IODP) Expedition 355 in two locations where it is $\sim 300 \mathrm{~m}$ (Site U1456) and $200 \mathrm{~m}$ thick (Site

74 U1457). The top of this mass transport complex is defined by the presence of both reworked

75 microfossil assemblages and deformation structures; such as folding and faulting. The deposit

76 consists of two main phases of mass wasting, each which consists of smaller pulses, with (

77 generally fining-upward cycles, all emplaced just prior to $10.8 \mathrm{Ma}$. The base of the deposit at

78 each site is composed largely of matrix-supported carbonate breccia that is interpreted as the

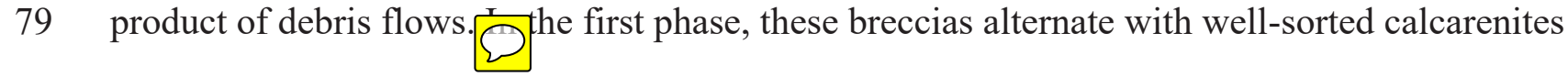

80 deposited from a high energy current, coherent limestone blocks that are derived directly from

81 the Indian continental margin, and a few clastic mudstone beds. In the second phase, at the top of

82 the deposit, muddy turbidites dominate and become increasingly more siliciclastic. At Site

83 U1456, wh both phases are seen, a 20-m section of hemipelagic mudstone is present, overlain

84 by a $\sim 40 \mathrm{~m}$ thick section of calcarenite and slumped interbedded mud and siltstone. Bulk

85 sediment geochemistry, heavy--mineral analysis, clay mineralogy, isotope geochemistry, and

86 detrital zircon $\mathrm{U}-\mathrm{Pb}$ ages constrain the provenance of the clastic, muddy material to being

87 reworked Indus-derived sediment, with input from western Indian rivers (e.g., Narmada and

88 Tapti Rivers), and some material from the Deccan Traps. The carbonate blocks found within the

89 breccias are shallow-water limestones from the outer western Indian continental shelf that was

90 oversteepened from enhanced clastic sediment delivery during the mid-Miocene. The final

91 emplacement of the material was likely related to seismicity as there are modern analogues for 
92 intraplate earthquakes close to the source of the slide. Although we hypothesize this area is at

93 low risk for future mass wasting events, it should be noted that other oversteepened continental

94 margins around the world could be at risk for mass failure as large as the Nataraja Slide.

\section{INTRODUCTION}

97 Large-scale mass wasting of continental margins is an important process in controlling

98 the geomorphology of continental slopes fringi 111 ocean basins (Coleman and Prior, 1988).

99 The scale of large mass transport complexes (MTCs) makes them significant as geohazards,

100 directly through mass wasting (Dan et al., 2007; Yamada et al., 2012), by generating tsunamis

101 (Tappin et al., 2001), as well as posing risks for seafloor infrastructure such as oil and gas

102 platforms, pipelines (Bea et al., 1983), and communication cables (Hsu et al., 2008). Moreover,

103 the emplacement of MFCs can have significant influence on the stratigraphy of deep ocean

104 basins, as well as for the continental margin from which it was derived.

105 Although the largest mass transport deposits are associated with active margins (Burg et

106 al., 2008), where earthquakes are more common and can act as triggers for emplacement, passive

107 margins are also recognized to host some of the largest gravitational collapses in the modern

108 oceans (Embley and Jacobi, 1977). Seismic surveying in the eastern Arabian Sea offshore

109 western India has identified one of the largest such complexes, totaling around 19,000 $\mathrm{km}^{3}$

110 (Calvès et al., 2015). Mapping of the deposit by seismic methods suggests that it may be up to

$111800 \mathrm{~m}$ thick in places (Calvès et al., 2015). In 2015 this deposit was drilled by International

112 Ocean Discovery Program (IODP) during Expedition 355. During the expedition, the MTC was

113 sampled on its southern edge, where the thicknesses were considerably thinner (Pandey et al.,

114 2016c)(Fig. 1). The deposit, named the Nataraja Slide, shows substantial run out from its inferred 


\section{(2)}

115 source regions offshore Saurashtra (Fig. 1), being emplaced $\sim 500 \mathrm{~km}$ into the Indian Ocean. In

116 this study, we examine the sedimentary rocks recovered by IODP in order to infer the

117 depositional mechanisms active during emplacement. We further make inferences about what

118 processes triggered its formation, which is dated as being just before 10.8 Ma (Pandey et al.,

119 2016a). Are MTCs of this magnitude formed by the sa processes that we see at much smaller

120 scales, or are these mega-scale complexes unique in their modes of emplacement and triggers?

121 Given the profound potential geohazards for human settlements in coastal regions, understanding

122 the origins and impacts of the Nataraja Slide MTC are of both great scientific and societal

123 significance.

124

125 GEOLOGY OF LARGE MTCS

126 Mass transport complexes are an extreme form of gravity induced sediment transport

127 (Hampton et al., 1996). Most submarine gravity driven sediment transport involves redeposition

128 of individual sediment particles suspended in water (e.g., in a turbidity current) or as a fluidized

129 sediment suspension (e.g., a debris flow or mud flow)(Pickering et al., 1986; Talling et al.,

130 2012). Sediment may also be mobilized when the proportion of water is very low, such as a

131 slow--moving sediment grain flow or creep (Carter, 1975; Lowe, 1976). However, large volumes

132 of material can also be transported rapidly (hours to days) in the form of slope failures where

133 coherent masses of material can be transported by sliding, rolling, falling, and/or slumping

134 (Coleman and Prior, 1988). Slumps involve displacement of a stratigraphic package above a

135 concave-upward detachment surface and can leave the slumped material in a relatively

136 undisturbed state after removal from an area that then shows an arcuate scar (Hampton et al.,

137 1996; Moore, 1961). Slumps differ from slides in that motion is along a pre-existing weakness, 
138 such as a bedding plane or joint surface, but the displaced package can move as a coherent mass,

139 or can be become disaggregated depending on the length and speed of transport. Significant

140 progress has been made in understanding mass transport through outcrop studies, such as the

141 Carboniferous (Pennsylvanian) Ross Slide of Ireland (Martinsen and Bakken, 1990; Strachan,

142 2002), the Eocene of the Pyrenean foreland basin (Farrell, 1984), and the Pliocene of Sicily

143 (Trincardi and Argnani, 1990). In all examples, each MTC was emplaced over a sharply defined

144 basal décollement once the deposit reached the lower slope after erosive mass wasting of the

145 steeper upper slope.

146 The geometry and internal structure of any gravitationally driven slump, slide or debris

147 flow reflect the mechanism of failure and the morphology of the slope where the transport occurs

148 (Lucente and Pini, 2003). The style of deformation and the mode of transport are controlled by

149 sediment and rock rheology that in turn are dependent on the lithology and strain rate. For this

150 reason, the largest MTCs are different from shallow debris flows and slumps because they

151 incorporate both lithified and unconsolidated materials. There are few exposures of very large

152 MTCs and those in the oceans are hard to access, especially through drilling. MTCs are often

153 seismically homogeneous (Vardy et al., 2010) but can show important changes in sediment

154 facies with depth and with distance from their source. For example, swath bathymetric mapping

155 of the Ebro margin in the western Mediterranean featuring the pre-11 ka BIG'95 Slide shows

156 that only finer sediments have reached the most distal areas, yet coherent rafts of continental

157 margin sedimentary rock are seen at the base of the slope (Lastras et al., 2004). Analysis of the

158 geometry and distribution of sedimentary facies and structures can be used to reconstruct the

159 evolving sedimentary and deformational strain history of any individual MTC. By doing so, it is

160 possible to derive a kinematic model of emplacement that can be compared with other examples. 
162 transport complex. This MTC is entirely siliciclastic and its generation has been linked to sliding

163 on $D^{\text {ourite sand and silts that became overpressured as a result of rapid burial by glacial }}$

164 maximum aged debris-flow sediments (Bryn et al., 2005). However, rapid sedimentation on any

165 clastic margin receiving sediment from the continent would provide weak layers on which

166 sliding could occur. Overpressuring has also been linked to growth and migration of silica

167 diagenetic fronts (Davies and Clark, 2006). Slope oversteepening increases the chances of mass

168 wasting simply by the consequence of rapid sediment delivery, although the tendency may be

169 heightened by the pre-existing basement structure of the continental margin (Lastras et al., 2004).

170 Slope oversteepening by itself cannot explain large-scale mass wasting because giant MTCs on

171 European continental margins are mostly associated with low gradient glacial margins. In

172 contrast, turbidity currents appear to dominate on steeper non-glacial margins might

173 otherwise be expected to suffer mass wasting due to their gradient (Leynaud et al., 2009). In

174 these cases, differences in the sediment types and the timing of sediment delivery favor

175 gravitational instabilities at different times, with non-glaciated margins tending to mass waste

176 more during sealevel lowstands, where the opposite more often occurs on glaciated margins.

177 Modelling indicates that continental margins with more cohesive clay-rich sediments tend to

178 experience coherent sliding more frequently than sand-rich margins whose gravitational slides

179 tend to disintegrate i (C) turbidity currents (Elverhoi et al., 2010).

180 The triggering of MTC emplacement can be attributed to a number of potential processes,

181 including seismicity (Moernaut et al., 2007; Piper et al., 1985), volcanic eruptions (Carracedo,

182 1999) and meteorite impacts (Klaus et al., 2000; Parnell, 2008). Dissociation of gas hydrates

183 during times of warming seawater could have aided liquefaction in the case of Storegga Slide 
184 (Mienert et al., 2005), with seismicity possibly related to post-glacial isostatic rebound providing 185 the final impetus for redeposition (Evans et al., 2002). In the eastern Mediterranean Sea, MTC 186 emplacement has also be linked to biogenic gas and slope oversteepening acting individually or 187 in tandem with one another (Frey Martinez et al., 2005).

188 Mechanisms for MTC emplacement differ between clastic and carbonate margins. This is

189 because carbonate sediment production occurs in situ and can result in steep platform margins, 190 sometimes almost vertically where reef complexes develop in outer shelf areas. Carbonate 191 production is strongly linked to sealevel and was fastest when sealevel was high after the onset 192 of Northern Hemispheric Glaciation (NHG, 2.4 Ma)(Schlager et al., 1994). Many carbonate

193 MTCs are linked to platform margin collapse and result in deposits with numerous coherent 194 blocks suspended within a more fluidized matrix. Seismic mapping around the Great Bahama 195 Bank has identified coherent Plio-Pleistocene sedimentary rock rafts $0.5-2.0 \mathrm{~km}$ in length, $0.3-$ $1961.5 \mathrm{~km}$ in width, and $50 \mathrm{~m}$ in thickness (Principaud et al., 2015). Adjacent deposits have also 197 been observed on the Florida margin (Mullins et al., 1986), as well as offshore Nicaragua (Hine, 198 1992), all with a similar Plio-Pleistocene age. Plio-Pleistocene MTCs are larger than most known 199 older examples because the rapidly changing sealevel since the start of the NHG enhanced 200 carbonate production and induced gravitational instability as sealevel rose and fell (Schlager et 201 al., 1994). Among these older deposits, only the Cretaceous Ayabacas MTC of Peru is 202 noteworthy for its large volume, long run out and presence of slide blocks measuring kilometers 203 in length (Callot et al., 2008). 
The Nataraja Slide lies within the Laxmi Basin offshore the western continental margin

207 of India (Fig. 1A and B). The Laxmi Basin is separated from the main Arabian Basin by the

208 Laxmi Ridge (Fig. 1). The Laxmi Basin is a rift basin that formed between India and the Laxmi

209 Ridge prior to the opening of the main Arabian Sea in the early Paleocene (Bhattacharya et al.,

210 1994), where the ridge is generally interpreted to be a rifted fragment of Indian continental crust

211 (Pandey et al., 1995). The age of rifting is somewhat controversial, but likely just predates the

212 emplacement of the Deccan Traps flood basalts in the latest Cretaceous, based on analysis of

213 magnetic anomalies (Bhattacharya et al., 1994) and the geochemistry of the basalts sampled at

214 IODP Site U1457 (Pandey et al., 2016b). The sediments in the Laxmi Basin can be divided into

215 three major units described below. The oldest, dated as Lower Paleocene, largely comprises red-

216 brown mudstones eroded from peninsular India and sampled at IODP Site U1457 (Pandey et al.,

217 2016b). These deposits are overlain by the Nataraja Slide and by younger distal turbidite

218 sandstones and siltstones, as well as hemipelagic mudstones that form the Indus submarine fan.

219 These latter sediments were supplied through the Indus River via erosion from the western

220 Himalaya and Karakoram (Pandey et al., 2016c). The age of the Indus Fan in the Laxmi Basin is

221 not well defined, although within the main Arabian basin the fan is typically considered to date

222 from at least $45 \mathrm{Ma}$, continuing to the present time (Clift et al., 2001). It is within these deposits 223 that the Nataraja Slide (MTC) was emplaced just before $10.8 \mathrm{Ma}$.

224 Towards the east, the Laxmi Basin is bounded by the rifted passive margin of India,

225 which has been supplied by sediment from the erosion of the peninsula via a number of

226 significant rivers that drain towards the west (e.g., Mahi, Tapti, and Narmada). Oil exploration

227 drilling has furthermore identified significant repeated buildups of carbonate on the shelf,

228 especially towards the shelf edge where the supply of clastic material was more limited (Rao and 
229 Talukdar, 1980; Wandrey, 2004). It is generally presumed that extensional deformation in the 230 area ceased after the rifting that formed the Laxmi Basin. The area has been largely seismically

231 inactive except towards the north where the Rann of Kutch forms an active structure within the

232 Indian Craton. This structure is linked to flexure of the plate as a result of the collision between

233 India and Asia (Bilham et al., 2003; Biswas, 2005), presumed to have started in the Eocene

234 (Najman et al., 2010) or earlier (DeCelles et al., 2014). Towards the north, the Indian

235 peninsula is cut by the NE-SW-trending Cambay Basin which formed as an initial early

236 Cretaceous rift that was then reactivated in the Cenozoic and experienced significant inversion in

237 the early Miocene (Chowdhary, 2004).

238 The MTC run-out distance is estimated to be about $550 \mathrm{~km}$, with a rength of $338 \mathrm{~km}$ and

239 a maximum width of $193 \mathrm{~km}$ (Calvès et al., 2015). Prior work on the Nataraja Slide found this

240 MTC to be acoustically homogenous in seismic lines, with few identified rafts preser 2 nd to

241 have a flat, rather than significantly angular erosive base over older deposits (Fig. 2)(Calvès et

242 al., 2015; Pandey et al., 2016c). However, closer inspection in the vicinity of the drilling sites

243 finds this is not always the case. In the case of IODP Site U1456 where the slide is somewhat

244 thicker, there is a significant missing section of submarine fan turbidites from $\sim 15.6$ to $10.8 \mathrm{Ma}$

245 (Pandey et al., 2016a). In that area the upper part of the deposit appears to be more acoustically

246 washed out and homogenous, but the lower regions are marked by strong reflections that show

247 limited lateral continuity suggestive of some internal structure within the deposit. This raises the

248 possibility that this is not simply a single depositional package (Fig. 2). Such strong reflections

249 are reminiscent of coherent slide blocks seen in seismic images of other MTCs (Gamboa et al.,

250 2012; Krastel et al., 2012; Principaud et al., 2015). The same is not true at the more distal Site 
251 U1457 location where the MTC onlaps the Laxmi Ridge and its acoustic character is more 252 uniform.

\section{METHODS}

Sedimentary cores were collected and initially described during IODP Expedition 355,

256 but several cores are re-examined in order to obtain more detailed descriptions of critical

257 sedimentary structures and facies. In addition to preparing sedimentary logs designed to

258 highlight the contrasting sedimentary facies, samples for sediment petrography were examined to

259 allow investigation into the different sediment types at both the macro and microscopic scale.

260 These methods allowed us to better define the depositional processes that operated during

261 Nataraja Slide emplacement and to provide constraints on the origin(s) of the MTC.

262 Geochemica thods were employed in order to further constrain the provenance of the

263 trrterials, and in particular, to verify the proposed western Indian continental margin source for

264 much of the MTC argued by Calvès et al. (2015). This approach is predicated on the fact that

265 source rocks of MTC deposits have different bulk geochemical compositions and that Himalayan

266 sources can be effectively discriminated from peninsular sources when considering provenance

267 due to different bedrock source compositions and contrasting chemical weathering histories.

268 Forty-four samples were selected for determination of major element composition,

269 together with select trace elements (Ni, Ba, V, Zr, Sc, Y, Sr). These were determined by

270 inductively coupled plasma emission spectrometry (ICP-ES) at Boston University, with precision

271 quantified to be better than $2 \%$ of the measured value for all elements. Accuracy was constrained

272 by analysis of certified Standard Reference Materials (BHVO-2) and results were accurate within

273 precision. Table 1 provides analyses of samples as well as repeated analyses of the standard. 
The neodymium $(\mathrm{Nd})$ isotope compositions of sediments are generally considered to be

275 minimally affected by chemical weathering, such that source terranes faithfully translate their

276 isotopic signature to eroded sediments (i.e., Goldstein et al. (1984)) and can be utilized for

277 sedimentary provenance studies. Strontium (Sr) isotopes are additionally considered, while

278 recognizing that $\mathrm{Sr}$ isotope compositions may be affected by chemical alteration largely during

279 transport across flood plains (Derry and France-Lanord, 1996). Together these isotopic systems

280 have a record of being powerful provenance proxies in the Arabian Sea (e.g., (-Clift and

281 Blusztajn, 2005; Clift et al., 2008a)). Care was taken to decarbonate samples prior to analysis

282 with $20 \%$ acetic acid because Sr isotope compositions are strongly controlled by carbonate

283 compositions and this study targets the siliciclastic sediment compositions only. Decarbonation

284 lasted for six days until no further fizzing was observed when samples were exposed to

285 unreacted acid. Samples were washed deionized water before being ground into powders.

286 Twenty-five samples were selected throughout the Nataraja Slide/MTC at Sites U1456 and

287 U1457 for the determination of ${ }^{143} \mathrm{Nd} /{ }^{144} \mathrm{Nd}$ and ${ }^{87} \mathrm{Sr} /{ }^{86} \mathrm{Sr}$ values. Isotopic compositions were

288 determined by Finnigan Neptune multi-collector inductively coupled plasma mass spectrometer

289 (MC-ICP-MS) at the Woods Hole Oceanographic Institute for both $\mathrm{Nd}$ and Sr isotopes. Nd and

290 Sr isotope analyses were corrected against La Jolla $\mathrm{Nd}$ standard ${ }^{143} \mathrm{Nd} /{ }^{144} \mathrm{Nd}=0.511847$ and

291 NBS987 standard ${ }^{87} \mathrm{Sr} /{ }^{86} \mathrm{Sr}=0.710240$. Procedural blanks were $20-25 \mathrm{pg}$ for $\mathrm{Sr}$ and $50-70 \mathrm{pg}$ for

292 Nd. We calculate the parameter $\epsilon_{\mathrm{Nd}}$ after (DePaolo and Wasserburg, 1976) using a ${ }^{143} \mathrm{Nd} /{ }^{144} \mathrm{Nd}$

293 value of 0.512638 for the Chondritic Uniform Reservoir (CHUR) (Hamilton et al., 1983).

294 Results are presented in Table 2.

295 Heavy-mineral analysis was the study the mineralogy of the MTC deposits in

296 order to further constrain the source of the materials and to estimate the potential impact of 
297 diagenetic dissolution. Sediment left after thin section preparation was gently crushed in water

298 with mortar and pestle and wet-sieved using a standard $500 \mu \mathrm{m}$ steel sieve and a special

299 handmade $15 \mu \mathrm{m}$ tissue-net sieve. A wide size window $(15-500 \mu \mathrm{m})$ was chosen to include a

300 large range of the size distribution (Garzanti et al., 2009). A gravimetric separation of dense

301 grains was achieved with a centrifuge using Na-polytungstate (density $2.90 \mathrm{~g} / \mathrm{cm}^{3}$ ), and heavy

302 minerals recovered by partial freezing in liquid nitrogen. An appropriate amount of the dense

303 fraction thus obtained was split with a micro-riffle box and mounted with Canada balsam. Heavy

304 minerals were counted under a polarizing microscope with the area method (Mange and Maurer,

305 1992). Grains of uncertain character were systematically checked and identified by an inViaTM

306 Renishaw Raman spectrometer, equipped with a $532 \mathrm{~nm}$ laser and a 50x LWD objective (Andò

307 and Garzanti, 2014). Heavy-mineral and transparent-heavy-mineral concentrations (HMC and

308 tHMC indices of Garzanti and Andò (2007), representing fundamental parameters for

309 unravelling provenance and detecting hydraulic-sorting effects and diagenesis, allow us to

310 distinguish poor (tHMC $<1)$, and very rich $(\mathrm{tHMC}>10)$ transparent-heavy-mineral suites. The

311 resulting assemblages were compared with those of modern sediments of the Tapti River

312 (sampled at $21^{\circ} 08^{\prime} 40.7^{\prime \prime} \mathrm{N}, 72^{\circ} 44^{\prime} 08.1^{\prime \prime} \mathrm{E}$ ) and Indus River. Results are presented in Table 3.

$313 \quad \mathrm{U}-\mathrm{Pb}$ dating of detrital zircon has been widely used for provenance analysis in siliciclastic

314 systems because zircon is a common mineral in continental rocks of many compositions and is

315 chemically and mechanically resistant to weathering during transport (Carter and Bristow, 2003).

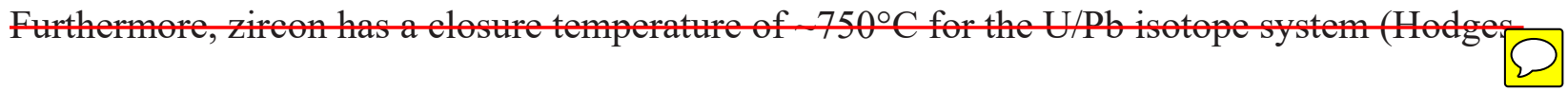

317 2003), making it very robust and unsuseeptible to ehange during multiple stages of recyeling.

318 Mineral separation and grain mounting were performed at GeoSep Services (GSS) Laboratory,

319 Moscow, ID. Only one sample was analyzed for zircon U-Pb dating because much of the core 
320 lacked suitable layers for this method. Zirc pere separated via hand picking and used for age 321 dating as described by Donelick et al. (2005). This process enhances the recovery of all possible 322 grain sizes while minimizing the potential loss of smaller grains within a sample by the use of 323 water-table devices. The method used by Donelick et al. (2005) further ensures the preservation 324 of complete grains by minimizing grain breakage and/or fracturing that can be associated with 325 traditional procedures of isolating individual grains from whole rock samples. Recovered zircon 326 were mostly medium silt to fine sand-sized grains. Epoxy wafers containing zircon grains for 327 laser ablation inductively coupled plasma mass spectrometry (LA-ICP-MS) were polished 328 manually using $3.0 \mu \mathrm{m}$ and $0.3 \mu \mathrm{m} \mathrm{Al}_{2} \mathrm{O}_{3}$ slurries to expose internal zircon grain surfaces. The 329 polished grain surfaces were washed in $5.5 \mathrm{M} \mathrm{HNO}_{3}$ for $20 \mathrm{sec}$. at $21^{\circ} \mathrm{C}$ in order to clean the 330 surfaces prior to introduction into the laser system sample cell.

331 A total of 51 individual zircon grains were targeted for data collection using a New Wave

332 YP213 $213 \mathrm{~nm}$ solid state laser ablation system with a $20 \mu \mathrm{m}$ diameter laser spot size, $5 \mathrm{~Hz}$ laser

333 firing rate, and ultra-high purity $\mathrm{He}$ as the carrier gas. Isotopic analyses of the ablated zircons

334 were performed using a ThermoScientific Element 2 magnetic sector mass spectrometer using 335 high purity Ar as the plasma gas. Ages from the ratios ${ }^{207} \mathrm{~Pb} /{ }^{235} \mathrm{U},{ }^{206} \mathrm{~Pb} /{ }^{238} \mathrm{U}$, and ${ }^{207} \mathrm{~Pb} /{ }^{206} \mathrm{~Pb}$

336 were calculated for each data scan and checked for concordance. Concordance was defined as 337 overlap of all three ages at the $1 \sigma$ level. If the number of concordant data scans for a spot was 338 greater than zero, the more precise age from the concordant-scan-weighted ratio ${ }^{207} \mathrm{~Pb} /{ }^{235} \mathrm{U}$, $339{ }^{206} \mathrm{~Pb} /{ }^{238} \mathrm{U}$, or ${ }^{207} \mathrm{~Pb} /{ }^{206} \mathrm{~Pb}$ was chosen as the preferred age, and whichever exhibited the lower 340 relative error. If zero concordant data scans were observed, the common $\mathrm{Pb}$-corrected age based 341 on isotopic sums of all acceptable scans was chosen as the preferred age. Results of zircon U-Pb 342 dating are shown in Table 4. 
Clay mineralogy was examined for provenance purposes based on the concept that different

344 environmental conditions and source terranes can produce characteristic assemblages. This

345 allows us to separate material derived from the Indus River from material more closely linked to

346 peninsular India. Although there may have been some change in mineralogy during initial

347 diagenesis, the relatively shallow burial depths of these cores means that there is no significant

348 thermal diagenesis and we can consider the observed mineralogy to be largely representative of

349 that at the time of sedimentation.

350 Clay mineralogy was determined by using X-Ray Powder Diffraction (XRD) at Louisiana

351 State University using a Panalytical Empyrean X-Ray Diffractometer. Forty selected samples

352 within the MTC were soaked in water until there was no flocculation, with $\mathrm{Na}_{3} \mathrm{PO}_{4}$ added to de-

353 flocculate when necessary. Samples were centrifuged for separation of the $<2 \mu \mathrm{m}$ material. Four

354 XRD patterns were generated from each oriented sample smear. The first pattern was collected

355 from the sample in air-dried conditions. The second XRD pattern was generated from a

356 glycolated sample after the slide was then placed in a desiccator with ethylene glycol for a

357 minimum of $8 \mathrm{~h}$ at $25^{\circ} \mathrm{C}$. t. The third and fourth XRD datasets were collected after the sample

358 was subjected to heat treatments of $300^{\circ} \mathrm{C}$ for $1 \mathrm{~h}$, and then $550^{\circ} \mathrm{C}$ for $1 \mathrm{~h}$, respectively. XRD

359 analysis began immediately after glycolation, and immediately after the first heat treatment. In

360 this study we use the semi-quantitative method of Biscaye (1965) to estimate the clay

361 assemblage, which is based on peak-intensity factors determined from calculated XRD patterns

362 as measured by MACDIFF software. For clay minerals present in amounts $>10 \mathrm{wt} \%$ uncertainty

363 is estimated as better than $\pm 5 \mathrm{wt} \%$ at the $95 \%$ confidence level. Uncertainty of peak area

364 measurement based on repeated measurements is typically $<5 \%$. Data are presented as relative

365 concentrations of the total clay assemblage in Table 5. 
DEFINING THE TOP AND BASE

Microfossil assemblages within the sediments provide constraints on the age of emplacement. The oldest sediment overlying the MTC was ed at around 10.8 Ma based on nannofossil assemblages and paleomagnetic stratigraphy (Pandey et al., 2016c). In Hole U1456D

371 the first appearance of Discoaster hamatus (10.55 Ma) marks the top of Zone NN8 (Pandey et 372 al., 2016a), while in Hole U1457C the interval 859.49-995.93 mbsf contains Catinaster coalitus, 373 which has a total age range of 9.69-10.89 Ma (Pandey et al., 2016b). The presence of Discoaster 374 bellus (first appearance at $10.40 \mathrm{Ma}$ ) within this interval also constrains the age to between 9.69 375 and 10.40 Ma. Much of the interval from 1009.21 to 1054.34 mbsf at Site U1457 contains a 376 mixture of different nannofossil species.

Above the MTC is a coherent assemblage of nannofossils suggestive of hemipelagic

378 sedimentation and not the mixed assemblage of early Neogene and Paleogene forms found 379 within the MTC, as might be associated with a reworked deposit. We use this noticeable change 380 in nannofossil assemblage as a criteria for defining the top of the MTC. In this study we define 381 both a sedimentary and biostratigraphic top from the core, as well as the top inferred from the 382 strong reflector in the seismic image, typically associated with massive carbonate beds. The 383 sedimentary top of the deposit marks the transition from sediment that is clearly slumped or 384 tilted in the core and appears to have been affected by syn-sedimentary deformation (Figs. 3 and 385 4) while the biostratigraphic top represents the transition from reworked into pristine nannofossil 386 assemblages. The difference in depth, $\sim 35 \mathrm{~m}$, is significant and could represent continued 387 slumping and reworking of young sediments after the initial emplacement of the main MTC 388 bodies. 
The base of the complex is easily established in both drilling sites, being marked by the

390 presence of carbonate breccias immediately overlying fine-grained sediments (Figs. 3 and 5).

391 The depth of this contact is 1101.65 and $1054.1 \mathrm{mbsf}$ at Sites U1456 and U1457, respectively. A

392 key observation is that in the thicker Site U1456 section there is a 20-m-thick interval in which

393 normal hemipelagic sedimentation was briefly reestablished, based on the lack of reworking in

394 the nannofossil assemblages. This spans from around 956 to $935 \mathrm{mbsf}$ (Figs. 3 and 6). This

395 shows that the MTC must have been emplaced in at least two phases separated by a pause,

396 despite the fact that this is not apparent in the seismic image. What is surprising is that the top of

397 this hemipelagic hiatus in mass wasting is not marked by a fresh influx of clearly reworked

398 brecciated carbonate material. Much of the hemipelagic interval comprises massive or parallel-

399 laminated mudstones with a couple of medium-bedded to massive sandstones representing less

400 than $10 \%$ of the section (Fig. 6A). This is only moderately different from the material which lies

401 above the hemipelagic layer that is characterized by mudstones interbedded with thin beds of

402 siltstone. Above the hemipelagic layer, however, there is clear evidence for slump folding, tilted

403 bedding and microfaulting, which testifies to the redeposited character of these sequences, as

404 well as the mixed nannofossil assemblage. It is only in the somat shallower part of the

405 seetion at Site U1456 there is evidence for a fresh influx of very coarse redeposited carbonate

406 debris flow material, above 874.2 mbsf(Fig. 3A).

407 At both sites, the topmost part of the deposit largely comprises fine-grained, bioturbated

408 claystones and clay-rich siltstones that are otherwise hard to distinguish from the background

409 deposits of the Indus submarine fan, especially when they are not deformed. Tilted bedding is

410 suggestive of deformation but might be interpreted as being coring related. The presence of 
411 slump folds close to the sedimentary top of each drilled section is, however, more conclusive in

412 demonstrating continued mass wasting above the coarser grained basal units.

\section{SEDIMENTARY FACIES}

415 The sedimentary facies within the MTC were determined on the basis of core

416 descriptions and, in particular, the analysis of sedimentary structures that give clues to the

417 depositional processes that were operating during emplacement. We here describe the major

418 sediment types and provide interpretations of the depositional mechanisms. These are

419 summarized in Figure 3.

\section{$421 \quad$ Limestones}

422 Short intervals of the MTC comprise coherent sections of fine-grained limestone that

423 show little evidence for the action of high energy reworking depositional processes. Limestones

424 are found at Site U1456 within the lower part of the section around 1050 mbsf depth (Fig. 3).

425 The limestones are typically massive and generally fine-grained micrite with moderate amounts

426 of clay that give them an off-white color. Heavily bioturbated sediment with vertical Zoophycos

427 trace fossils are typical of sedimentation in moderately deep water, often close to the shelf edge

428 (Fig. 7A)(Ekdale et al., 1984; Seilacher, 1967). Figure 7B shows a massive micritic limestone

429 with some evidence of bioturbation, but which indicates minor recrystallization along stylolites,

430 highlighted by thin clay-rich partings. Neither deposit contains indication of strong current

431 activity, such as ripples or laminations, or even a well sorted granular texture, but rather

432 sedimentation in a low energy carbonate-rich environment probably below storm-wave base

$433(<40 \mathrm{~m})($ Peters and Loss, 2012). Short intervals of limestone are also found at Site U1457 very 
434 close to the base of the MTC 1050 mbsf. These are granular and porous and may be the product

435 of higher energy sedimentation in relatively shallow water depths $(<30 \mathrm{~m})$. Again, the limestones

436 are tan-colored rather than being pure white that is indicative of a modest clay content. Given the

437 modern significant water depth (3523 $\mathrm{m}$ at Site U1457) we propose that these limestones

438 represent coherent blocks of relatively shallow water material that were emplaced as part of the

439 brecciated units near the base of the MTC.

\section{Carbonate Breccia Debrites}

442 The vast majority of the carbonate sediment in the MTC are breccia clasts found mostly

443 in the bottom part of the deposit at Site U1456 (970-1101 mbsf), with further yet more limited

444 clasts in the upper part of the MTC at the same site. They are also found immediately above the 445 base of the MTC at Site U1457 (Fig. 3). These breccias are thick-bedded, ranging close to $20 \mathrm{~m}$ 446 thick for individual beds separated by finer grained units. At Site U1456 there are multiple such 447 breccia units; stacked on top of each other, that are preferentially developed towards the base of 448 the sequence. The breccias are sometimes overlain by calcarenites (described below) or by 449 mudstones with a sharp boundary between the two lithologies. The breccias are extremely 450 poorly-sorted and the individual clasts are angular to sub-angular. Clast size ranges up to and 451 greater than the width of the core $(>10 \mathrm{~cm})$. There is usually no trend towards fining or 452 coarsening upwards within individual units, although one coarsening upwards sequence is seen 453 in Section U1456D-43R-1 (860 mbsf). The fabric of the sediment is rarely clast-supported (Fig. 454 8A) but is normally suspended in a dark muddy matrix (Fig. 8B).

455 The limestone clasts are pale tan to bright white with the interior showing a very fine456 grained or slightly granular sediment classified as micrite or more rarely packstone and 
457 wackestone (Dunham, 1962). In the part of the section densest in limestone clasts ( $\sim 1036$ mbsf at 458 Site U1457), clasts are seen to indent one another both in core surfaces (Fig. 8A), as well as in 459 microscope thin sections (Fig. 9D). We interpret this as a result of dissolution during diagenesis 460 and burial.

461 The vast majority of the carbonate rocks redeposited in the debris flows appear to have 462 been lithified prior to their resedimentation. In combination with the observation of angular 463 clasts, we see coherent rafts of sediment ( $>10 \mathrm{~cm}$ width) floating within finer grained material 464 (Fig. 8B). There is some evidence that some of the carbonate sediment was not lithified during 465 emplacement because soft sediment folding of the deposits, such as seen in muddy limestones 466 (Fig. 10A) can be observed. However, these deformed deposits only represent a relatively small 467 part of the total sequence. It is elear brittle deformation is important locally, especially 468 between and within the more coherent carbonate blocks. Slickensides especially testify to rapid 469 brittle deformation of the carbonate rocks during their emplacement (Fig. 8C). Most of the debris 470 flow units are extremely poorly-sorted but sometimes are represented by coarse sandstones 471 devoid of larger clasts (Fig. 8D). In these, larger granular clasts are supported in a muddy 472 sandstone matrix with no clear grading within the unit.

473 Although limestone fragments dominate the debris flows, it is noteworthy that in places 474 there is evidence for reworking of volcanic rocks into the flows (Fig. 10B). These clasts are 475 weathered red-brown and are sub-rounded. The largest single clast was found at $879 \mathrm{mbsf}$ at Site 476 U1456 within a poorly indurated conglomeratic part of the debris flow sequence. The clast is an 477 8-cm-wide fragment of vesicular aphyric basalt that is presumed to be derived by erosion from 478 the Deccan Plateau volcanic sequences exposed across peninsular India. The clasts were likely 
eroded on to and then reworked across the continental shelf because being redeposited in the

480 MTC.

The limestone, from which the carbonate clasts were derived, formed as a typical

482 shallow-water deposit in a biologically productive zone mostly starved of clastic sediment input.

483 Original water depths were within the photic zone on the continental shelf or within a back-reef

484 setting $(<50 \mathrm{~m})$, with only moderate amounts of current activity, since we see no evidence for

485 strong sorting or high energy deposits such as oolites or grainstones (Dunham, 1962). These

486 original rocks have mostly been broken and reworked as debris flow deposits during the

487 emplacement of the MTC. The muddy matrix has a separate provenance, either from the deep-

488 water slope of peninsular India or from the Indus Fan itself, as discussed below.

\section{Calcarenites}

491 Calcarenite is present in each carbonate section, in the form of massive, well-sorted units

492 suggestive of high energy current transport. Beds of calcarenite are several meters thick and

493 generally massive and structureless, although they can develop a sub-horizontal fabric suggestive

494 of current flow. Where the deposits are finer (Fig. 10D), there is a shear-type fabric developed

495 within the calcareous siltstones. In the coarser grained units (Fig. 10C) there is some evidence

496 for internal soft sediment deformation, although generally the units are homogenous and

497 comprise uniform, gray, coarse-grained sandstone. They are well-sorted and clast-supported,

498 with very little muddy matrix, suggestive of a high energy depositional regime. The majority of

499 the clasts are carbonate, although there are a significant number of dark grains of organic carbon

500 origin. These calcarenites often have sharp tops that are interpreted to reflect erosion of the

501 deposit prior to the emplacement of overlying units. Figure 10D shows a calcareous siltstone 
502 sharply overlain by conglomeratic sandstones deposited as debris flows. Very few sedimentary

503 structures are seen within these deposits, so that we infer sedimentation in an upper flow regime

504 resulting in relatively laminar deposits without any current ripples or finer interbeds. Sediment

505 concentrations are inferred to have been very high during deposition, which terminated rapidly.

507 Turbidites and Hemipelagic Mudstones

Apart from the carbonate-dominated debris flows, minor turbidite sandstones and

509 dominant siltstones and mudstones make up the largest part of the MTC. These are also

510 interbedded with associated hemipelagic mudstones. In the coarsest sandstones, each turbidite

511 shows a classic fining upward sequence (Fig. 11A), with largest carbonate fragments suspended

512 in a dark clastic mud matrix. Locally, there are sub-horizonfal lamination although sedimentary

513 structures are poorly developed, with up-section fining dominating characteristic of these

514 deposits. In the upper parts of the MTC at both sites, muds show lamination and interbedding of

515 modest amounts of muddy silt (Fig. 11B). Elsewhere, the deposits are massive, dark gray

516 mudstones with few sedimentary structures. These contrast with the draping mudstones that

517 overlie the catastrophically emplaced MTC where typical deep-water trace fossil assemblages

518 (i.e., Zoophycos;(Fig. 11C) characterize the hemipelagic sedimentation and eliminate the

519 possibility of large-scale mass wasting. This is in contrast to the muddy upper sections of the

520 MTC itself, where there is evidence for laminar current flow that follows the initial emplacement

521 of the carbonate debris flow deposits at the base of each cycle. In general, the grain sizes are

522 relatively limited, with only few a thin-bedded sandstones and occasional siltstones developed

523 within what is otherwise a dominantly (95\%) muddy sequence. Distinguishing muddy sediment 
524 with the MTC from the hemipelagic interval within Site U1456 is difficult without the help of 525 micropaleontology evidence.

526 Syn-sedimentary deformation within the muddy turbidities include folds, micro-faults,

527 and tilted bedding (Fig. 11D) and are particularly easy to see in well-laminated sequences. Dip of

528 lamina can be high $\left(>50^{\circ}\right)$, indicating significant deformation of the muddy units after

529 sedimentation. In addition to ductile structures, there is evidence for compressional reverse

530 faulting. Significant dips and deformation are evidence for incorporation as part of the MTC

531 rather than the subsequent hemipelagic sedimentation of the Indus Fan, which is only gently

532 inclined like the seafloor or the top of the MTC $\left(\sim 1.2^{\circ}\right.$ according to Calvès et al. (2015)).

\section{Micro-Facies}

535 Petrographic analysis can be used to help interpret paleoenvironment and depositional

536 mechanisms from facies identified in the cores. Figure 9A shows a silty laminated mudstone

537 from the upper part of the MTC at Site U1457 that is interpreted here as a turbidite deposit. The

538 massive calcarenite beds that overlie debris flow conglomerates are seen to be relatively poorly

539 sorted and matrix supported, at least in places, in thin section (Fig. 9B). Clasts are rarely

540 composed of calcite crystals but are dominated by a variety of finer limestone facies, especially

541 micrite. Aggregates of dolomite crystals (Fig. 9C) interpreted to represent

542 diagenetic alteration of original calcite via interaction with magnesium-rich waters prior to

543 resedimentation. Their presence is suggestive of redeposition from shallow water areas where

544 this mineral generally forms.

545 There are large numbers of microfossils and their fragments within the breccia limestone

546 clasts. Foraminifers are abundant (Figs. 12A, 12B, 12F). In addition, we also confirm the 
547 presence of crinoid fragments (Fig. 12D), bryozoans, and rare radiolarians (Fig. 12E). The

548 skeletal assemblage of most limestone clasts is dominated by calcareous red algae and benthic

549 foraminifera (including both miliolids and large rotaliids; Fig. 12C). Rare echinoderms, mollusks

550 and hermatypic coral fragments are also present. Some skeletal grains, originating from a

551 shallow-water environment (coralline algae, large echinoid spines, large benthic foraminifera),

552 also occur within the matrix (Figs. 12H, 12I). The occurrence of what is likely to be Lockhartia,

553 together with the peyssoneliacean red-alga Polystrata alba, suggests that at least part of the

554 eroded limestone was of Paleogene age (Fig. 12C)(Bassi and Nebelsick, 2000; BouDagher-

555 Fadel, 2018). The matrix is largely dominated by planktonic foraminifera with minor

556 contribution from small rotaliids (Figs. 12G).

557 These characteristics suggest that the MTC involved both lithified inner platform deposits 558 (the source of limestone fragments) and outer platform deposits still composed of loose grains 559 (the source of the muddy matrix with planktonic foraminifera).

\section{DEPOSITIONAL MECHANISMS}

Most sediment within the MTC are either debris flow deposits, well-sorted calcarenites,

563 or dominantly clastic turbiditic siltstones and mudstones. Both phases of the MTC at Site U1456

564 (Fig. 3) show large-scale fining upwards cycles, with a dominance of carbonate debris flows

565 towards the base grading into more siliciclastic turbidite sedimentation towards the top. Smaller,

566 shorter phases of fining upwards cycles are further observed within the two overall fining

567 upwards cycles at Site U1456. For example, the upper part of Phase 1 (Fig. 3), comprises a basal

568 unit from between 999.2 and 984.0 mbsf that is dominated by rafted carbonate sheets and

569 carbonate debris flow material (Figs. 3 and 6B). This interval is likely a second pulse after the 
570 initial Phase 1 event. Above 984.0 mbsf there is a transition to massive thick-bedded calcarenite

571 with slump folds, although this is truncated sharply at $973 \mathrm{mbsf}$ by mudstones that rapidly

572 transition into the hemipelagic sediment described above (Fig. 6B). This implies that the basal

573 Phase 1 unit, especially at Site U1456 comprises a series of pulses rather than one single gigantic

574 deposit as might have been implied by the seismic data alone (c.f.(Calvès et al., 2015)(Fig. 2).

575 The base of Phase 1 at both sites is characterized by a thick-bedded sequence of debris

576 flow calcareous breccias and rafts of undeformed shallow water carbonate (Fig. 5). These are not

577 surprisingly the thickest such deposits within the entire drilled section. Although Site U1456 is in

578 a more central location within the basin, the oldest debris flow breccia at the base of Phase 1 is

579 thinner in this location than at Site U1457 and transitions more rapidly up into thick-bedded

580 breccia and interbedded calcarenites. Both sections, however, do show an overall fining upward

581 between the base and overlying mudstone units. The initial debris flow sedimentation appears to

582 be $\sim 94 \mathrm{~m}$ thick at Site U1456 (1101.6-1007.2 mbsf) and $\sim 48 \mathrm{~m}$ thick at Site U1457 (1006.4-

5831054.3 mbsf; Figs. 3 and 5).

584 In general, calcarenites alternate with debris flow conglomerates (Fig. 5A) indicating

585 alternating depositional mechanisms within a single emplacement episode. Individual debris

586 flow events are followed by high energy upper flow regime periods of sedimentation where

587 massive well-sorted calcarenites were deposited before being followed by another debris flow

588 unit. However, presumably all this material was emplaced over a relatively short period of time.

589 The carbonate-dominated debris flows form the initial erosive base of the MTC, followed by

590 mud-dominated turbidite sedimentation and hemipelagic fallout representing the tail of the MTC.

591 At Site U1456 this sequence is then repeated after the hemipelagic break. Soft sediment

592 deformation is commonly seen in the more laminated sections indicative of slumping after 
593 sedimentation. It seems unlikely that poorly consolidated mudstones and siltstones could have

594 been emplaced hundreds of kilometers in a semi-coherent form, unlike the well-lithified

595 limestone clasts seen close to the base of each section.

\section{GEOCHEMISTRY}

\section{Bulk Geochemistry}

We use a CN-A-K ternary diagram to illustrate major element geochemistry of MTC

600 samples compared to sediments from the Indus Canyon and delta. The sediment from the MTC

601 largely plots within the range of the Indus Canyon and trends towards higher values of $\mathrm{Al}_{2} \mathrm{O}_{3}$

602 (Fig. 13A). MTC samples appear to have higher values that trend towards the illite end-members 603 and may be more depleted in biotite and feldspars compared to the delta. This is likely a result of

604 sediment transport, similar to what has been observed in the Indus Canyon (Li et al., 2018).

605 Sediments in the muddy upper part of the MTC at Site U1457 largely plot with low

606 Chemical Index of Alteration (CIA), which is a proxy of the state of weathering of a sediment

607 compared to pristine bedrock (Nesbitt et al., 1980). The muddy upper MTC samples trend more

608 towards the Quaternary Indus Delta field compared to the lower parts of both Phase 1 and Phase

609 2, which show more overlap with western Indian Shelf sediments, largely derived from rivers

610 draining the Deccan Plateau (Kurian et al., 2013). This plot implies that the upper muddy

611 sediments at Site U1457 had a dominant source from the Indus River/Fan and little inputs from

612 western peninsular India.

613 The sediment in the MTC can also be characterized using other major element

614 discrimination diagrams. Figure 13B shows the scheme of Herron (1988) in which the Phase 1

615 and Phase 2 samples largely plot within the Fe shale field, with a few slightly depleted in Fe and 
616 plotting as shales. Again, we plot these samples along with the western Indian Shelf, Indus

617 Canyon and delta sediments. Samples from the upper muddy top to Phase 1 at Site U11457 form

618 a cluster within the range of the Indus Canyon sediments, suggesting a dominant provenance of

619 reworked Indus material. Comparison with sediment from the western Indian shelf shows a

620 significant difference, with the shelf sediment typically plotting with much higher Fe contents,

621 similar to the lower Phase 1 and 2 sediments. We infer that the bulk of the sediment in the lower

622 MTC comprises mostly Indian margin sediment with muddy top dominated by sediment eroded

623 and redeposited from the Indus Fan.

$625 \quad$ Nd and Sr Isotopes

626 We use Sr and Nd isotope values to constrain the provenance of siliciclastic sediment in 627 the MTC. By cross-plotting Nd and Sr isotopic compositions from source regions such as the 628 Deccan Traps, peninsular Indian rivers, Transhimalaya, Karakoram, Greater Himalaya, Kirthar 629 and Sulaiman Ranges, and modern/Quaternary Indus-derived sediment allows the origin of the 630 sediment to be further constrained (Fig. 14). This diagram shows that the MTC samples form a 631 relatively discrete cluster with one exception that has especially positive $\varepsilon$ Nd values that fall 632 within the Deccan and Transhimalayan arrays. When we compare these data with potential 633 sources, it is clear that the bulk of the sediments lie within the isotopic range defined by the 634 Indus submarine fan sediments at the same drilling sites (Clift et al., 2018). This is consistent 635 with the argument that much of this material may be reworked Indus-derived sediment.

636 However, we note that it is impossible to exclude mixing of sediment from the peninsular Tapti 637 or Narmada Rivers. The isotope compositions by themselves do not allow us to quantify the 638 degree of reworking from these sources as they are similar to the Indus. Although the MTC 
639 samples plot with higher $\varepsilon$ Nd values compared to the Quaternary Indus Canyon, as well as the

640 Kirthar and Sulaiman ranges, such a composition could largely be explained through temporal

641 variation in the Indus River itself (Clift and Blusztajn, 2005; Clift et al., 2018). The one very

642 positive $\varepsilon_{\text {Nd }}$ sample is anomalous and plots with even more positive values than the Tapti River.

643 This is strongly suggestive of erosion from peninsular India and is corroborated by the presence

644 of vesicular Deccan Plateau basalt fragments as previously noted.

645 We can look at the stratigraphic variation in isotopic compositions through time at both

646 sites (Fig. 15). In both cases, Nd isotope compositions plot within error of the Quaternary Indus

647 or with slightly more positive $\varepsilon$ Nd values. We note that the most positive $\varepsilon$ Nd values in each

648 borehole are found within the debris flow conglomerate units bearing basaltic clasts at the base

649 of the lower part of the MTC. This is especially true at Site U1456 (Fig. 15A). Variations in

$650 \quad{ }^{87} \mathrm{Sr} /{ }^{86} \mathrm{Sr}$ also mirror this general evolution.

651 The provenance of the coarse-grained carbonate debris flow deposits is different from

652 those of the finer grained sediments overlying them. The fine-grained sediments may represent

653 recycling of pre-existing fan sediments into the top of the MTC, while the debris flow deposits

654 are more closely associated with mass wasting from the western Indian continental margin. It is

655 possible that some Indus River sediment could have been transported east along the shelf, carried

656 by longshore currents from the river mouth, and deposited offshore Saurashtra before being

657 redeposited as part of the MTC. However, there is no evidence that significant Indus sediment

658 travels farther east than the Rann of Kutch (Khonde et al., 2017; Kurian et al., 2013). The

659 simplest interpretation is that the upper muddy layers of the MTC represent entrained and 660 reworked Indus Fan material.

661 


\section{Heavy Mineral Analysis}

The heavy-mineral assemblages help to constrain the source area of the MTC. The

664 concentration of heavy minerals in all samples is very low suggesting a strong depletion due to

665 intrastratal dissolution of unstable silicates (Garzanti, 2017). Consequently, a relative enrichment

666 of ultrastable minerals is observed (ZTR index of Hubert (1962)). The two samples (U1456E-

667 15R-1W, 61-63 cm and U146E-17R-4W, 131-133 cm), analyzed from the carbonate breccia

668 present extremely low HMC $(0.04-0.05 \%)$ with common augitic clinopyroxene $(\sim 6 \%)$ and rare

669 spinel (2-3\%). The minerals also show corroded surficial textures, indicating a strong diagenetic

670 overprinting (Ando et al., 2012). A similar fingerprint is detected in Sample U1456E-7R-1, 80-

$67182 \mathrm{~cm}$ where green and brown augite are abundant (48\%). In all these samples, there are

672 common garnets associated either with apatite, titanite, epidote, zircon, tourmaline, and

673 metamorphic Ca-amphiboles, potentially derived from recycled sediments from the Himalaya-

674 derived Indus Fan turbidites eroded by the MTC. Notwithstanding diagenetic dissolution, the

675 highly unstable augitic clinopyroxene (volcanic origin) always dominates over metamorphic

676 amphiboles, suggesting a sizable contribution to the MTC from the Indian passive margin, and

677 especially from Deccan Plateau basaltic lavas. Sample U1456E-4R-1W, 110-111 cm is a

678 calcarenite within which hydraulic sorting and high-energy currents preferentially selected the

679 available heavy minerals suite derived from the MTC, concentrating platy heavy minerals such

680 as chloritoid, Ca-amphiboles and tourmaline (lighter). The sample is partially depleted in denser

681 garnet. This assemblage is completed with the presence of abundant apatite, common titanite,

682 epidote and spinel with trace of kyanite, andalusite and staurolite.

683 Sample U1457C-88R-4W, 58-60 cm was deposited far from the Indian Passive margin

684 and the mineralogy reflects a dominant contribution from recycled minerals derived from the 
685 erosion and re-deposition of the Indus Fan turbidites. The tHMC is very low (0.08\%), and

686 mineralogy is dominated by abundant epidote and garnet with common apatite and titanite. Ca-

687 amphiboles dominate over clinopyroxenes, with a ratio 8:1, pointing to a major contribution

688 from the Indus River and the Himalaya in this sample. The assemblage also includes tourmaline,

689 zircon, chloritoid, Cr-spinel and trace of and kyanite, staurolite and andalusite.

690 The modern Tapti River was analyzed close to its mouth. The sample contains a very rich

691 assemblage of heavy minerals (tHMC 17\%) with dominant augitic clinopyroxenes (92\%) and

692 subordinate amount of metamorphic heavy-mineral, Ca-amphiboles, epidote, garnet and

693 sillimanite. This mineralogical signature differs from the observed suite of orogenic heavy

694 minerals observed in the modern Indus River and his delta (Garzanti et al., 2005).

695 The heavy mineral assemblage in the MTC and the very low concentration of heavy

696 minerals points to different sources for the siliciclastic sediments, i.e., partially derived axially

697 from the Himalayas via the Indus River (especially at Site U1457C) and partially derived

698 transversally from the Indian peninsula (especially at Site U1456).

699

700 Zircon U-Pb Ages

701 To further constrain provenance, we compare detrital zircon $\mathrm{U}-\mathrm{Pb}$ ages with existing data

702 from the Indus river mouth (Clift et al., 2004), Indus Fan turbidites above and below the MTC

703 (Clift et al., 2018), and with bedrock data from potential sources in the river catchment (Fig.

704 16)(DeCelles et al., 2000; Gehrels et al., 2011). Although the zircon ages from source bedrock

705 overlap with each other, each source regions demonstrates strong preferential age spectra that

706 can be used to discriminate between them. Zircons from Nanga Parbat, Kohistan, the

707 Transhimalaya, and the Karakoram generally have younger ages ( $<300 \mathrm{Ma})$ than those from the 
708 Himalayan ranges (Alizai et al., 2011)(Fig. 16). Both the Greater and Tethyan Himalaya have U-

$709 \mathrm{~Pb}$ age peaks at 300-750 Ma and 750-1250 Ma, with older ages at $\sim 1850 \mathrm{Ma}$ characterizing the

710 Lesser Himalaya

711 The volume of sample available for U-Pb dating from Core U1457C-7R (the only suitable

712 sediment seen in the MTC) was extreme $\triangle$ mited such that only 51 grains yielded concordant

713 ages, which is somewhat lower than the 113 minima suggested by Vermeesch (2004) for a

714 sample with complex provenance. Nonetheless, some inferences concerning provenance can be

715 made. What is clear is that young ages dominate with 17 grains dated at less than $100 \mathrm{Ma}$ (Fig.

716 16). The age spectrum bears most similarity with Indus Fan turbidites dated at 7.8, 8.3, and 15.6

717 Ma, but all are in contrast with the ages from the modern river. The match between these young

718 grains and sources in the Karakoram and Kohistan argue for the sand to be an Indus-derived

719 sediment and not from sediment transported from the Indian peninsula where zircon ages are

720 Paleozoic or typically much older. This conclusion is consistent with the $\mathrm{Nd}$ and $\mathrm{Sr}$ isotope data

721 from the upper parts of the MTC. The analyzed sandstone was sampled below the

722 sediment/structurally defined top of the MTC but above the carbonate-dominated debris flow

723 facies at the base of the complex, i.e., within the muddy but slumped top of the MTC. This

724 implies that the upper parts of the MTC are Indus Fan sediments entrained in the tail of the MTC 725 during emplacement.

\section{Clay Mineralogy}

728 The clay mineral assemblages within the MTC can be used to assess provenance by

729 semiquantitative analysis and comparison with existing data from other sources. When plotted on

730 the ternary diagram of (illite+chlorite), kaolinite, and smectite (Fig. 17) there is significant 
731 overlap between the new MTC data and other Arabian Sea sediments (Rao and Rao, 1995). In

732 general, the MTC clays are low in kaolinite and form an array between the smectite and

733 (illite+chlorite) end members. In this respect, they show a similar character to sediments from the

734 Indus fan and have significant overlap with Quaternary clays from the Indus Canyon (Li, 2018).

735 Samples from Phase 1 of the MTC have very high smectite contents, similar to the Paleocene

736 sediments overlying basement at Site U1457, suggestive of a volcanic source. They are close to

737 sediments recovered from the inner shelf offshore Saurashtra and from the Gulf of Cambay.

738 Phase 2 sediments and the hemipelagic layer are slightly less smectite rich but overlap with the

739 Holocene Indus Shelf, as well as some modern Indian Shelf sediments. We note that the bulk of

740 the muddy upper Phase 1 sediments plot with higher (illite+chlorite) values and they also tend to

741 have slightly higher kaolinite compared with analyses of sediments from the Indus floodplains

742 (Alizai et al., 2012). These sediments are similar to the assemblage recognized from the outer

743 Saurashtra margin (Rao and Rao, 1995) and are similar to many clay assemblages within Indus

744 Fan turbidite sequences. Overall, the MTC deposits have lower kaolinite compared with most

745 Western Indian shelf deposits but some samples plot closely to the shelf. It is also noteworthy

746 that the MTC assemblages generally show lower (illite+chlorite) compared with many of the

747 Miocene-Recent Indus submarine fan deposits, which likely indicates a mixed provenance of

748 Indus and Indian peninsular sediment. However, because illite and chlorite are the product of

749 physical weathering rather than chemical weathering their relatively high contribution to the

750 MTC could also indicate reduced chemical weathering of fan sources since MTC emplacement.

751 These data are consistent with a dominant recycling of Indus Fan deposits in the upper muddy

752 parts of the MTC, but with greater involvement of clays derived from the Western Indian margin 
753 in the lower part, especially in Phase 1. The similarity with modern nearshore sediments offshore

754 Saurashtra and Cambay is consistent with an origin in this part of the margin.

755 Clay mineralogy shows significant variation with depth (Fig. 15). At Site U1456 the

756 carbonate-rich part of the section shows particularly high smectite contents and relatively low

757 (illite+chlorite) values. Smectite only becomes less abundant than these two physically

758 weathered clays above the upper Phase 2 carbonate debris flow unit. At Site U1457 the

759 carbonate-rich part of the section similarly is smectite-rich, but immediately above this level the

760 sediments become dominated by an (illite+chlorite) assemblage similar to the Indus Fan. It is

761 noteworthy that the Paleocene sediments beneath the MTC at Site U1457 are 100\% smectite,

762 possibly reflecting chemical weathering of the underlying basaltic basement. Clay mineralogy

763 supports the $\mathrm{Nd}$ and $\mathrm{Sr}$ isotope compositions in showing a characteristic difference between the

764 carbonate-dominated sections that indicate similarity to the western Indian margin, whereas the

765 mudstone dominated sequences further upsection in the MTC are most similar to compositions

766 associated with the Indus Fan.

768 SEDIMENT BUDGET

769 To assess the potential of sediment delivery rates and margin oversteepening as triggering

770 mechanisms of the MTC, a sediment budget from the western Indian margin was generated using

771 standard two-dimensional backstripping methods from seismic profile data (Clift, 2006; Kusznir

772 et al., 1995). This was to primarily test the hypothesis that the rapid accumulation of sediment on

773 the continental margin resulted in an unstable stratigraphy that was then more liable to mass

774 wasting events like the Nataraja MTC. There is strong evidence that the Western Indian

775 continental margin is gravitationally unstable as a result of the large-scale compressional thrusts 
776 seen in seismic profiles towards the base of the continental slope seen between the Saurashtra

777 shelf and Bombay High (Fig. 1)(Calvès et al., 2015; Nair and Pandey, 2018). These features are

778 often associated with slopes prone to gravitational collapse, which in this region, has yet to

779 manifest in the dramatic fashion of the Nataraja MTC. In order to estimate the mass flux of the

780 margin, we use the cross-margin seismic reflection profile of Nair and Pandey (2018)(Figs. 1 and

781 18). Their northernmost profile lies immediately south of the scarp region identified by Calvès et

782 al. (2015) and which we consider to be potentially representative of the sedimentation in the

783 source regions of the MTC prior to its redeposition. For the purpose of this study, we use the age

784 control provided by Nair and Pandey (2018), at least for the continental shelf and slope areas

785 (Fig. 18A). West of the toe of the slope sedimentation is linked to the Indus Fan and may not be

786 representative of the mass flux to the Saurashtra Shelf. Figure 18A shows the interpretation of

787 Nair and Pandey (2018) with a conversion from their seismic travel time scale to depth made on

788 the basis of multichannel seismic stacking velocities derived from the Indus shelf, as used by

789 Clift et al. (2002)(Table 6). We do this because of the absence of such data from the Saurashtra

790 region itself. We prefer to use velocity data from the Indus continental shelf rather than from the

791 deep basin because as the sediment thicknesses are much greater under the continental shelf, they

792 are more comparable to those seen offshore the Indus River mouth. Based on the lateral

793 variability in velocities seen on the Indus Shelf, we estimate that this conversion may introduce

794 uncertainties as high as $\pm 20 \%$ (Clift, 2006). Stratigraphic ages are then assigned numerical ages

795 based on the timescale of Gradstein et al. (2012).

796 The depth-converted line was then backstripped using standard decompaction methods

797 (Kusznir et al., 1995; Sclater and Christie, 1980). This was done to restore each dated sediment

798 layer to its original thickness prior to burial. Knowledge of the sediment type is important to this 
calculation because shales experience much greater loss of porosity during burial than do sandstones (Sclater and Christie, 1980), and in this case, we used lithological data from Wandrey

801 (2004) and Rao and Talukdar (1980). These studies show a mixed Cenozoic sequence dominated

802 by silty muds and carbonates offshore Saurashtra. The decompaction process involves

803 accounting for the loss of porosity of the sediment during burial, which would otherwise result in

804 an underestimation of deposited volumes for the older, deeper buried sediment packages. After

805 the original, uncompacted volume of sediment in each dated interval has been determined, the

806 mass of rock delivered during that time period can be calculated. Errors in lithology and

807 compaction history are much smaller than the time-depth conversion and rarely exceed 5\%.

808 In this study two-dimensional decompaction was calculated using the program Flex-

$809 D_{\text {Decomp }}^{\mathrm{TM}}$ (Kusznir et al., 1995). It must be assumed that the analyzed profile is representative

810 of the total mass flux to the margin since rifting of the Arabian Sea $\sim 66 \mathrm{Ma}$ (Bhattacharya et al.,

811 1994). Because we only have one profile close to the area of mass wasting, and no estimate of

812 the total sediment mass offshore Saurashtra, it is not possible to make a volume calculation.

813 However, the two-dimensional budget does at least allow us to estimate the volumes of sediment

814 delivered per kilometer of margin close to the source of the MTC. Our results show a clear trend

815 to increasing mass flux after $26 \mathrm{Ma}$ (Fig. 18B), with a peak between 16 and $11 \mathrm{Ma}$. Because the

816 resolution of the budget is constrained by the presence of the dated horizons, it is not possible to

817 accurately say when the peak sediment flux was achieved, but this analysis confirms that the

818 Middle Miocene was a time of rapid sedimentation offshore Saurashtra, a pattern that it shares

819 with many other Asian delta systems. As a result, it seems likely that the pulse was caused by

820 faster erosion driven by heavy summer monsoon rains (Clift, 2006). We suggest that much of the

821 gravitational instability on the western Indian margin was caused by rapid sedimentation in the 
822 Middle Miocene causing oversteepening of the shelf edge, comprising large thicknesses of

823 sediment liable to incomplete dewatering during burial. The reducing sedimentation rates after

82411 Ma may explain why a second such slide has not been emplaced in this part of the margin.

826 SEISMICITY

As well as an over-steepened continental margin caused by increased sediment flux, we 828 investigate the possible triggering of the MTC as a result of seismic activities that are often 829 implicated in the emplacement of large mass wasting complexes (Kastens, 1984). Figure 1 shows

830 the location of earthquakes greater than 4.5 magnitude since 1960 in the vicinity of the source

831 region for the MTC. There is some seismicity related to the plate boundary west of the Indus

832 delta and there are small amounts of activity in the Saurashtra Peninsula itself, immediately

833 opposite the scar in the continental shelf. It is apparent that the greatest concentration of seismic

834 activity is however around the Rann of Kutch, where historic intraplate events up to 7.7

835 magnitude have been recorded (Bilham, 1999). This activity reflects reactivation of earlier rift-

836 related faults due to compression linked to the India-Eurasia collision (Bilham et al., 2003;

837 Biswas, 2005). This part of the Indian plate is a weak zone and may well have been active as a 838 seismic hotspot for significant periods of time. We suggest that it is the relative proximity of the

839 Saurashtra margin to this tectonic feature $(<300 \mathrm{~km})$ may have initiated the mass wasting 840 in that region, rather than further south along the margin where sediment flux was also high.

\section{SYNTHESIS AND CONCLUSIONS}


845 surveying of the deposit. At Site U1456, there is clear evidence that the MTC was emplaced in 846 two major phases separated by a significant break (Fig. 19). Even the larger, earlier Phase 1 can

847 be broken down into at least two stages, indicative of pulsed emplacement. The basal part of

848 each drilled section of the complex comprises debris flow carbonate breccias and larger rafts of

849 shallow water limestone, which can be traced back to collapse of the carbonate edge of the

850 continental shelf offshore Saurashtra. The MTC is emplaced as a number of fining upward

851 sequences with debris flow breccias, overlain by well sorted, coarse calcarenite deposited by

852 high velocity currents following in the wake of the initial mass wasting landslide. These are

853 overlain by muddy and turbiditic deposits, which are increasingly siliciclastic in character. At

854 Site U1457, only a thinner section of the earlier Phase 1 appears to be preserved, but a second

855 Phase 2 is apparent at Site U1456. Again, there was an emplacement of carbonate-rich debris

856 flows, although these were preceded and followed by muddy turbidite deposits, largely reworked

857 from pre-existing sediments of the Indus Fan. The top of each drilled sequence shows a

858 separation between sediment where the biostratigraphy is mixed and where slumping continues

859 to occur in the aftermath of the original depositional event.

$860 \mathrm{Nd}$ and $\mathrm{Sr}$ isotopic data, together with heavy-mineral assemblages, show that the

861 siliciclastic fraction of the deposit is associated with the western Indian continental margin, at

862 least in the debris flow part of the deposits although the overlying muddy turbidite units share the

863 same characteristics as the Indus submarine fan and suggest entrainment of sediment already

864 deposited in Laxmi Basin in the wake of the carbonate-rich debris flows that formed the MTC in

865 the first place. Limited zircon data at Site U1457 also show the clear signature of the Indus

866 River, although this applies only to the muddy units overlying the carbonate debris flows. We

867 envisage that enhanced sediment delivery to the western Indian continental margin driven by 
868 strong monsoon during the middle Miocene resulted in an oversteepened continental margin that

869 was in a gravitationally unstable state. Exactly what triggered the collapse is not clear, but may

870 well be related to seismic activity in the nearby Rann of Kutch where large earthquakes continue

871 to the present day. Compressional deformation structures in the western Indian continental

872 margin south of Saurashtra suggest that this region too is in a compressional and potentially

873 unstable situation. However, decreasing sediment flux to the continental margin since the middle

874 Miocene has lessened the instability of the continental slope and reduced the chance of mass

875 wasting, especially further south away from potential seismic triggers. The western Indian

876 margin, however, has also experienced the increasing sedimentation rates linked to the onset of

877 northern hemisphere glaciation and so the potential for significant geohazard still exists.

878 Nonetheless, the fact that there has been no similar large event since 10.8 Ma does argue for this

879 being relatively low risk at the present time.

880

881 Acknowledgments

882 This work was made possible by samples given by International Ocean Discovery

883 Program. Project funding came from the Charles T. McCord Jr Chair in Petroleum Geology at

884 LSU. We thank Alan Roberts and Nick Kusznir for use of FlexDecomp software. 


\section{Figure Captions}

888 Figure 1. A) Shaded topographic and bathymetric map of the Arabian Sea showing the location 889 of the core sites discussed in this study (yellow dots). Base map from GeoMapApp. Dashed 890 yellow lines show proposed continent-ocean boundaries. Dashed white lines show oceanic 891 transform faults. Numbered red circles indicate existing scientific boreholes from Deep Sea 892 Drilling Project (DSDP) and Ocean Drilling Program (ODP). Pink squares shor 1 ajor cities. 893 Magnetic anomalies (thin gray numbered lines) are from Miles et al. (1993). Green-filled circles 894 show earthquakes >4.5 magnitude since 1960 recorded by US Geological Survey. B) Close-up 895 map of Laxmi Basin showing the precise location of the drill sites. A pink dashed line shows the 896 extent of the Nataraja MTC (Calvès et al., 2015). Light blue lines show locations of seismic 897 profiles shown in Figure 2.

899 Figure 2. Seismic profiles of the core sites (left) with interpretation (right) showing the mass900 transport complex in the immediate vicinity of (A) IODP Site U1456 and (B) IODP Site U1457. 901 Modified from Pandey et al. (2016c). See Figure 1 for locations of lines.

902

903 Figure 3. Summary stratigraphic columns showing the lithologies and interpreted facies of the 904 mass-transport complex at (A) IODP Site U1456 and (B) IODP Site U1457. Black shading in 905 second column indicates recovery, with white showing lost section. mbsf = meters below 906 seafloor.

907

908 Figure 4. (A) Sedimentary log showing the top of the deposit, U1456D-33R to U1456D-42R; (B) 909 Sedimentary log showing the top of the deposit, U1457C-69R to U1457C-78R. Black shading in 
910 second column indicates recovery, with white showing lost section. $\mathrm{mbsf}=$ meters below

911 seafloor.

912

913 Figure 5. (A) Sedimentary log showing the bottom of the MTC, U1456E-16R to U1456E-19R;

914 (B) Sedimentary log showing bottom of the MTC, U1457C-86R to U1457C-92R. Lithological

915 patterns and sedimentary structures same as Figure 4. Black shading in second column indicates 916 recovery, with white showing lost section. $\operatorname{mbsf}=$ meters below seafloor.

918 Figure 6. (A) Sedimentary log showing the deposit above and within the hemipelagic layer, 919 U1456D-50R to U1456D- 53R. As shown, soft sediment deformation occurs until pelagic layer 920 begins; (B) Sedimentary log showing the second pulse of carbonate debris flow material, 921 U1456D-56R to U1456D-61R. Lithological patterns and sedimentary structures same as Figure 922 4. Black shading in second column indicates recovery, with white showing lost section. mbsf $=$ 923 meters below seafloor.

924

925 Figure 7. (A) Limestone with burrows (20 cm long), U1456E-12R-1, $42-47 \mathrm{~cm}$ (1045 mbsf); (B) 926 Stylolite in limestone, U1456E-10R-3, 30-40 cm (1030 mbsf). Vertical scale is in cm below the 927 section top. See locations on Figure 3.

928

929 Figure 8. (A) Coarse carbonate breccia with mudstone matrix, U1457C-90R-2, 75-83 cm (1036

930 mbsf); (B) Debris flow conglomerate with faulted mudstone raft (larger faults shown with white 931 lines), U1456E-9R-4, 78-88 cm (1021 mbsf); (C) Core photograph of slickensides on a fault 932 within silty claystone, U1456E-9R-4, 37-51 cm (1021 mbsf), (D) Coarse sandy, calcarenite, 
933 U1457C-88R-5, 38-48 cm (1022 mbsf). Vertical scale is in cm below the section top. See

934 location on Figure 3.

935

936 Figure 9. Thin section plane polarized photomicrographs of (A) Laminated sandy siltstone with 937 quartz grains, U1457C-85R-1, 22-26 cm (997 mbsf). Note the finer muddy center of the image 938 and the poorly sorted silt interbeds on either side with dominant quartz clasts; (B) Calcarenite, 939 U1456D- 60R-1, 13-17 cm (1006 mbsf); (C) Euhedral calcite/dolomite crystals within larger 940 grain, U1456E-15R-1, 12-16 cm (1073 mbsf); (D) Suture grain contact of carbonate clasts in 941 breccia, U1456D-45R-4-52-57 cm (870 mbsf). See location on Figure 3.

943 Figure 10. (A) Slump folded calcareous siltstone, U1456D-58R-2, 43-53 cm (989 mbsf); (B) 944 Deccan vesicular basalt clast, U1456D-46R-1, 16-25 cm (879 mbsf); (C) Massive calcarenite 945 with ductile folded layer U1456D-41R-3A, 114-124 cm (841 mbsf); (D) Sharp contact between 946 calcarenite and calcareous siltstone, U1457C-88R-7, 61-70 cm (1025 mbsf). Vertical scale is in $947 \mathrm{~cm}$ below the section top. See location on Figure 3.

949 Figure 11. (A) Sandy siltstone showing gradual normal grading, U1457C-71R-3, 101-115 cm 950 (865 mbsf) (B) Tilted, laminated turbidite deposit U1457C- 73R-2, 140-148 cm (881 mbsf); (C) 951 Mudstone with Zoophycos burrows (one outlined for clarity), U1457C-68R-1, 42-52 cm (832 952 mbsf); (D) Steeply dipping laminated mudstone showing reverse faulting, U1456D-46R-3A, $953139-148 \mathrm{~cm}$ (883 mbsf). Vertical scale is in $\mathrm{cm}$ below the section top. See location on Figure 3 954 
955 Figure 12. Thin section plane polarized photomicrographs of (A) Uniserial benthic foraminifer in

956 breccia clast, U1456E-15R-1, 12-16 cm (1072 mbsf); (B) Siltstone with planktonic foraminifers,

957 U1456D-58R-2, 40-44 cm (989 mbsf); (C) Limestone clast with a specimen of Lockhartia,

958 U1456E-17R-4, 131-133 cm (1086 mbsf); (D) Echinoderm spine in carbonate clast, U1456D-

959 61R-2, 44-48 cm (1017 mbsf); (E) Foraminifer fragments in siltstone, U1456D-58R-2, 40-44 cm

960 (989 mbsf); (F) Planktic foraminifers and bioclasts in carbonate breccia, U1457C-90R-1-6-10 cm

961 (1034 mbsf). G) Planktonic foraminifer, U456E-7R-1, 80-82 cm (999 mbsf); H) Fragments of

962 coralline algae (white arrows) included in the planktonic-foraminifer-dominated matrix; Plk=

963 planktonic foraminifer, U1457C-88R-4, 58-60 cm (1021 mbsf); I) Orthophragminid fragment

964 (white arrow) included in the planktonic-foraminifer-dominated-matrix; Dl = dolomite crystal,

965 U1457C-88R-4, 58-60 cm (1021 mbsf). See locations on Figure 3.

966

967 Figure 13. (A) Geochemical signature of the analyzed samples illustrated by a CN-A-K ternary

968 diagram (Fedo et al., 1995). $\mathrm{CN}$ denotes the mole weight of $\mathrm{Na}_{2} \mathrm{O}$ and $\mathrm{CaO}^{*}(\mathrm{CaO} *$ represent the

$969 \mathrm{CaO}$ associated with silicate, excluding all the carbonate (Singh et al., 2005)). A and K indicate

970 the content of $\mathrm{Al}_{2} \mathrm{O}_{3}$ and $\mathrm{K}_{2} \mathrm{O}$ respectively. CIA values are calculated and shown on the left side,

971 with values correlated with on the CN-A-K ternary. Samples from the delta have the lowest CIA

972 values and indicate high contents of $\mathrm{CaO}$ and $\mathrm{Na} 2 \mathrm{O}$ and plagioclase. Abbreviations: sm

973 (smectite), pl (plagioclase), ksp (K-feldspar), il (illite), m (muscovite). B) Geochemical

974 classification of sediments from the Indus delta (Clift et al., 2010), Indus Canyon (Li et al., 2018)

975 and western Indian Peninsular shelf north of Goa (Kurian et al., 2013) following the scheme of

976 Herron (1988). Phase 1 and Phase 2 sediments, together with the hemipelagic drape are the

977 materials of the MTC. 
979 Figure 14. Cross plot of Sr versus Nd isotope data from the MTC, adjacent drill sites, major 980 source regions onshore, and modern Mahi, Tapti, and Narmada River sediments (Goswami et al., 981 2012). Kirthar and Sulaiman data is from Zhuang et al. (2015). Deccan Plateau data are from 982 GEOROC compilation (http://georoc.mpch-mainz.gwdg.de/georoc/). Transhimalaya data are 983 from Rolland et al. (2002), Singh et al. (2002), and Khan et al. (1997). Greater Himalayan data 984 are from Ahmad et al.(2000), Deniel et al. (1987), Inger et al. (1993) and Parrish and Hodges 985 (1996). Karakoram data are from Crawford and Searle (1992) and Schärer et al. (1990),

987 Figure 15. Downhole plots of $\mathrm{Nd}$ and $\mathrm{Sr}$ isotope compositions and clay mineralogy of 988 siliciclastic sediments from IODP sites (A) U1456 and (B) U1457. Gray vertical bar shows 989 compositional range of Quaternary sediments in the Indus Delta (Clift et al., 2010; Clift et al., 990 2008b), as well as modern Tapti and Narmada River sediments (Goswami et al., 2012). Deccan 991 Plateau volcanic rocks plot outside this range at more positive $\varepsilon_{\text {Nd }}$ values and lower ${ }^{87} \mathrm{Sr} /{ }^{86} \mathrm{Sr}$ 992 values. Nd and Sr isotope analyses include errors recently suggested by Jonell et al. (2018) for 993 bulk sediment compositions. Error bars encompass the total expected error for any bulk sample 994 as a result of variable grain size and mineralogy, and analytical error contributed during sample 995 preparation, homogenization, and analysis.

996

997 Figure 16. Kernel density estimate (KDE) plots for detrital zircon U-Pb ages for the Nataraja 998 MTC compared to major source terrains in the western Himalayas, from the compilation of 999 Alizai et al. (2011), as well as a modern sand from the river mouth (Clift et al., 2004) and select 1000 Indus Fan turbidites also from IODP Sites U1456 and U1457 (Clift et al., 2018). Deccan 2 mons 
1001 at $\sim 65$ Ma would plot within the Karakoram-Kohistan range but the inset box at the top shows

1002 that grains $<100 \mathrm{Ma}$ from the MTC do not cluster at this age and are better match to sources in

1003 the Indus suture zone. Data from the Tethyan, Greater and Lesser Himalaya are compiled from

1004 DeCelles et al. (2004). Karakoram data is from Le Fort et al. (1983), Parrish and Tirrul (1989),

1005 Schärer et al. (1990), Fraser et al. (2001) and Ravikant et al. (2009). Nanga Parbat data is from

1006 Zeitler and Chamberlain (1991) and Zeitler et al. (1993), Transhimalayan data is from Honegger

1007 et al. (1982), Schärer et al. (1984), Krol et al. (1996), Weinberg and Dunlap (2000), Zeilinger et

1008 al. (2001), Dunlap and Wysoczanski (2002), (Singh et al., 2007), and Ravikant et al. (2009).

1009

1010 Figure 17. Ternary diagram of clay minerals from IODP Site U1456 and U1457 indicates a clay

1011 mineral assemblage consisting mostly of smectite, chlorite and illite. Clay mineral data from

1012 source regions are plotted to compare their clay assemblages. Data from western Indian shelf

1013 modern sediments are from Rao and Rao (1995), Indus canyon data is from Li et al. (2018),

1014 Indus flood plain and delta data is from Alizai et al. (2012), and Indus Fan data is from Peng

1015 Zhou (unpublished).

1016

1017 Figure 18. (A) Interpretation of the depth-converted seismic section of the western Indian

1018 continental shelf immediately to the south of the source region for the Nataraja Slide based on

1019 the seismic profile of Nair and Pandey (2018) and using the seismic velocities shown in Table 5;

1020 and (B) A calculated sediment budget for the Indian shelf derived from two-dimensional

1021 sediment backstripping of this profile derived from FlexDecomp ${ }^{\mathrm{TM}}$ software.

1022 
1023 Figure 19. Schematic cartoon illustrating the over-steepened Indian margin (A), the first phase

1024 of emplacement of the Nataraja MTC (B) separated by a short time of quiescence with

1025 hemipelagic sedimentation (C) from the second smaller phase of emplacement (D).

1026

1027 Table 1. Bulk sediment geochemistry analyzed by ICP-ES.

1028

1029 Table 2. Neodymium and strontium isotope data.

1030

1031 Table 3 . Heavy mineral data. $\mathrm{HM}=$ heavy minerals; $\mathrm{tHM}=$ transparent heavy minerals. The

1032 ZTR index is the sum of zircon, tourmaline and rutile over total transparent heavy minerals

1033 (Hubert, 1962) and is classically used to estimate the mineralogical durability of the assemblage

1034 (i.e., the extent of recycling and/or intrastratal dissolution).

1035

1036 Table 4. U-Pb zircon data for sample U1456C-71R-1, $110 \mathrm{~cm}$.

1037

1038 Table 5. Quantitative estimates of major clay mineral assemblages.

1039

1040 Table 6. Seismic interval velocities for the main stratigraphic units interpreted by Nair and

1041 Pandey (2018) used to depth convert the seismic profile before backstripping.

1042

1043

1044 


\section{References}

1046

1047

1048

1049

1050

1051

1052

1053

1054

1055

1056

1057

1058

1059

1060

1061

1062

1063

1064

1065

1066

1067

1068

1069

1070

1071

1072

1073

1074

1075

1076

1077

1078

1079

1080

1081

1082

1083

1084

1085

1086

1087

Ahmad, T., Harris, N., Bickle, M., Chapman, H., Bunbury, J., and Prince, C., 2000, Isotopic constraints on the structural relationships between the Lesser Himalayan Series and the High Himalayan Crystalline Series, Garhwal Himalaya: Geological Society of America Bulletin, v. 112, no. 3, p. 467-477.

Alizai, A., Carter, A., Clift, P. D., VanLaningham, S., Williams, J. C., and Kumar, R., 2011, Sediment provenance, reworking and transport processes in the Indus River by U-Pb dating of detrital zircon grains: Global and Planetary Change, v. 76, p. 33-55. doi:10.1016/j.gloplacha.2010.11.008.

Alizai, A., Hillier, S., Clift, P. D., and Giosan, L., 2012, Clay mineral variations in Holocene terrestrial sediments from the Indus Basin; a response to SW Asian Monsoon variability: Quaternary Research, v. 77, no. 3, p. 368-381. doi:10.1016/j.yqres.2012.01.008.

Andò, S., and Garzanti, E., 2014, Raman spectroscopy in heavy-mineral studies. In Sediment Provenance Studies, in Scott, R. A., Smyth, H. R., Morton, A. C., and Richardson, N., eds., Sediment Provenance Studies in Hydrocarbon Exploration and Production, Volume 386: London, Geological Society, p. 395-412.

Ando, S., Garzanti, E., Padoan, M., and Limonta, M., 2012, Corrosion of heavy minerals during weathering and diagenesis: a catalogue for optical analysis: Sedimentary Geology, v. 280, p. $165-178$.

Bassi, D., and Nebelsick, J. H., 2000, Calcareous algae from the lower Oligocene Gornji Grad beds of Northern Slovenia: Rivista Italiana di Paleontologia e Stratigrafia, v. 106, p. 99-122.

Bea, R. G., Sircar, P., and Niedoroda, A. W., 1983, Wave-induced slides in South Pass Block 70, Mississippi Delta: Journal of Geotechnical Engineering, v. 109, p. 619-644.

Bhattacharya, G. C. B., Chaubey, A. K., Murty, G. P. S., Srinivas, S., Sarma, K. V., Subrahmanyam, V., and Krishna, K. S., 1994, Evidence for seafoor spreading in the Laxmi Basin, northeastern Indian Ocean: Earth and Planetary Science Letters, v. 125, p. 211-220.

Bilham, R., 1999, Slip parameters for the Rann of Kachchh, India, 16 June 1819, earthquake, quantified from contemporary accounts, in Stewart, I. S., and Vita-Finzi, C., eds., Coastal Tectonics, Volume 146: London, Geological Society, p. 295-319.

Bilham, R., Bendick, R., and Wallace, K., 2003, Flexure of the Indian Plate and intraplate earthquakes: Proceedings of the Indian Academy of Sciences (Earth and Planetary Sciences), v. 112,, p. 1-14.

Biswas, S. K., 2005, A review of structure and tectonics of Kutch basin, western India, with special reference to earthquakes: Current science, v. 88, no. 10, p. 1592-1600.

BouDagher-Fadel, M., 2018, Evolution and geological significance of larger benthic foraminifera, London, UCL Press, $702 \mathrm{p}$.

Bryn, P., Berg, K., Stoker, M. S., Haflidason, H., and Solheim, A., 2005, Contourites and their relevance for mass wasting along the Mid-Norwegian Margin.: Marine and Petroleum Geology, v. 22, p. 85-96.

Burg, J. P., Bernoulli, D., Smit, J., Dolati, A., and Bahroudi, A., 2008, A giant catastrophic mudand-debris flow in the Miocene Makran: Terra Nova, v. 20, no. 3, p. 188-193. 
1088

1089

1090

1091

1092

1093

1094

1095

1096

1097

1098

1099

1100

1101

1102

1103

1104

1105

1106

1107

1108

1109

1110

1111

1112

1113

1114

1115

1116

1117

1118

1119

1120

1121

1122

1123

1124

1125

1126

1127

1128

1129

1130

1131

1132

1133

Callot, P., Sempere, T., Odonne, F., and Robert, E., 2008, Giant submarine collapse of a carbonate platform at the Turonian-Coniacian transition: the Ayabacas formation, southern Peru: Basin Research, v. 20, p. 333-357.

Calvès, G., Huuse, M., Clift, P. D., and Brusset, S., 2015, Giant fossil mass wasting off the coast of West India: The Nataraja submarine slide: Earth and Planetary Science Letters, v. 432, p. 265-272. doi:10.1016/j.eps1.2015.10.022.

Carracedo, J. C., 1999, Growth, structure, instability and collapse of Canarian volcanoes and comparisons with Hawaiian volcanoes: Journal of Volcanology and Geothermal Research, v. 94, no. 1-4, p. 1-19.

Carter, A., and Bristow, C. S., 2003, Linking hinterland evolution and continental basin sedimentation by using detrital zircon thermochronology; a study of the Khorat Plateau basin, eastern Thailand: Basin Research, v. 15, p. 271-285.

Carter, R. M., 1975, A discussion and classification of subaqueous mass-transport with particular application to grain-flow, slurry-flow, and fluxoturbidites: Earth-Science Reviews, v. 11, no. 2, p. 145-177.

Chowdhary, L. R., 2004, Petroleum Geology of the Cambay Basin, Gujarat., India, Indian Petroleum Publishers, $171 \mathrm{p}$.

Clift, P., Gaedicke, C., Edwards, R., Lee, J., II, Hildebrand, P., Amjad, S., White, R. S., and Schlueter, H.-U., 2002, The stratigraphic evolution of the Indus Fan and the history of sedimentation in the Arabian Sea: Marine Geophysical Researches, v. 23, no. 3, p. 223 245.

Clift, P. D., 2006, Controls on the erosion of Cenozoic Asia and the flux of clastic sediment to the ocean: Earth and Planetary Science Letters, v. 241, no. 3-4, p. 571-580.

Clift, P. D., and Blusztajn, J. S., 2005, Reorganization of the western Himalayan river system after five million years ago: Nature, v. 438, no. 7070, p. 1001-1003.

Clift, P. D., Campbell, I. H., Pringle, M. S., Carter, A., Zhang, X., Hodges, K. V., Khan, A. A., and Allen, C. M., 2004, Thermochronology of the modern Indus River bedload; new insight into the control on the marine stratigraphic record: Tectonics, v. 23, no. TC5013. doi:10.1029/2003TC001559.

Clift, P. D., Giosan, L., Blusztajn, J., Campbell, I. H., Allen, C. M., Pringle, M., Tabrez, A., Danish, M., Rabbani, M. M., Carter, A., and Lückge, A., 2008a, Holocene erosion of the Lesser Himalaya triggered by intensified summer monsoon: Geology, v. 36, no. 1, p. 7982. doi: 10.1130/G24315A.1.

Clift, P. D., Giosan, L., Carter, A., Garzanti, E., Galy, V., Tabrez, A. R., Pringle, M., Campbell, I. H., France-Lanord, C., Blusztajn, J., Allen, C., Alizai, A., Lückge, A., Danish, M., and Rabbani, M. M., 2010, Monsoon control over erosion patterns in the Western Himalaya: possible feed-backs into the tectonic evolution, in Clift, P. D., Tada, R., and Zheng, H., eds., Monsoon evolution and tectonic-climate linkage in Asia, Volume 342: London, Geological Society, p. 181-213.

Clift, P. D., Hodges, K., Heslop, D., Hannigan, R., Hoang, L. V., and Calves, G., 2008b, Greater Himalayan exhumation triggered by Early Miocene monsoon intensification: Nature Geoscience, v. 1, p. 875-880. doi:10.1038/ngeo351.

Clift, P. D., Shimizu, N., Layne, G., Gaedicke, C., Schlüter, H. U., Clark, M. K., and Amjad, S., 2001, Development of the Indus Fan and its significance for the erosional history of the western Himalaya and Karakoram: Geological Society of America Bulletin, v. 113, p. 1039-1051. 
1134

1135

1136

1137

1138

1139

1140

1141

1142

1143

1144

1145

1146

1147

1148

1149

1150

1151

1152

1153

1154

1155

1156

1157

1158

1159

1160

1161

1162

1163

1164

1165

1166

1167

1168

1169

1170

1171

1172

1173

1174

1175

1176

1177

1178

1179

Clift, P. D., Zhou, P., Stockli, D. F., and Blusztajn, J., 2018, An Erosional Record of Regional Exhumation of the Western Himalaya and Karakoram: Nature Communications, v. in review.

Coleman, J., and Prior, D., 1988, Mass wasting on continental margins: Annual Review of Earth and Planetary Sciences, v. 16, no. 1, p. 101-119.

Crawford, M. B., and Searle, M. P., 1992, Field relationships and geochemistry of pre-collisional (India-Asia) granitoid magmatism in the central Karakoram, northern Pakistan: Tectonophysics, v. 206, no. 1-2, p. 171-192.

Dan, G., Sultan, N., and Savoye, B., 2007, The 1979 Nice harbour catastrophe revisited: trigger mechanism inferred from geotechnical measurements and numerical modelling: Marine Geology, v. 245, p. 40-64.

Davies, R., and Clark, I., 2006, Submarine slope failure primed and triggered by silica and its diagenesis: Basin Research, v. 18, p. 339-350.

DeCelles, P. G., Gehrels, G. E., Najman, Y., Martin, A. J., Carter, A., and Garzanti, E., 2004, Detrital geochronology and geochemistry of Cretaceous-Early Miocene strata of Nepal: implications for timing and diachroneity of initial Himalayan orogenesis: Earth and Planetary Science Letters, v. 227, no. 3-4, p. 313-330.

DeCelles, P. G., Gehrels, G. E., Quade, J., LaReau, B., and Spurlin, M., 2000, Tectonic implications of U-Pb zircon ages of the Himalayan orogenic belt in Nepal: Science, v. 288, no. 5465, p. 497-499. doi:10.1126/science.288.5465.497.

DeCelles, P. G., Kapp, P., Gehrels, G. E., and Ding, L., 2014, Paleocene-Eocene foreland basin evolution in the Himalaya of southern Tibet and Nepal: Implications for the age of initial India-Asia collision: Tectonics, v. 33, p. 824-849. doi:10.1002/ 2014 TC003522.

Deniel, C., Vidal, P., Fernandez, A., Fort, P., and Peucat, J.-J., 1987, Isotopic study of the Manaslu granite (Himalaya, Nepal): inferences on the age and source of Himalayan leucogranites: Contributions to Mineralogy and Petrology, v. 96, no. 1, p. 78-92.

Derry, L. A., and France-Lanord, C., 1996, Neogene Himalayan weathering history and river ${ }^{87} \mathrm{Sr} /{ }^{86} \mathrm{Sr}$; impact on the marine Sr record: Earth and Planetary Science Letters, v. 142, p. 59-74.

Donelick, R. A., O’Sullivan, P. B., and Ketcham, R. A., 2005, Apatite fission-track analysis: Reviews in Mineralogy and Geochemistry, v. 58, no. 1, p. 49-94.

Dunham, R. J., 1962, Classification of carbonate rocks according to depositional texture, in Ham, W. E., ed., Classification of Carbonate Rocks, Volume 1, American Association of petroleum geology, p. 108-121.

Dunlap, W. J., and Wysoczanski, R., 2002, Thermal evidence for Early Cretaceous metamorphism in the Shyok suture zone and age of the Khardung volcanic rocks, Ladakh, India: Journal of Asian Earth Sciences, v. 20, no. 5, p. 481-490.

Ekdale, A. A., Bromley, R. G., and Pemberton, S. G., 1984, Ichnology. Trace fossils in sedimentation and stratigraphy, Tulsa, OK, Society of Economic Palaeontologists and Mineralogists, Short Course, 317 p.

Elverhoi, A., Breien, H., Blasio, F. V. D., Harbitz, C. B., and Pagliardi, M., 2010, Submarine landslides and the importance of the initial sediment composition for run-out length and final deposit: Ocean Dynamics, v. 60, p. 1027-1046. doi 10.1007/s10236-010-0317-z.

Embley, R. W., and Jacobi, R. D., 1977, Distribution and morphology of large submarine sediment slides and slumps on Atlantic continental margins: Marine Georesources \& Geotechnology, v. 2, no. 1-4, p. 205-228. 
Evans, D., McGiveron, S., Harrison, Z., Bryn, P., and Berg, K., 2002, Along-slope variation in the late Neogene evolution of the mid-Norwegian margin in response to uplift and tectonism, in Dore, A. G., Cartwright, J. A., Stoker, S., Turner, J. P., and White, N., eds., Exhumation of the North Atlantic Margin: Timing, Mechanisms and Implications for Petroleum Exploration, Volume 196: London, Geological Society, p. 139-151.

Farrell, S. G., 1984, A dislocation model applied to slump structures, Ainsa Basin, South Central Pyrenees: Journal of Structural Geology, v. 6, p. 727-736.

Fedo, C. M., Nesbitt, H. W., and Young, G. M., 1995, Unraveling the effects of potassium metasomatism in sedimentary rocks and paleosols, with implications for paleoweathering conditions and provenance: Geology, v. 23, p. 921-924.

Fraser, J. E., Searle, M. P., Parrish, R. R., and Noble, S. R., 2001, Chronology of deformation, metamorphism, and magmatism in the southern Karakoram Mountains: Geological Society of America Bulletin, v. 113, no. 11, p. 1443-1455.

Frey Martinez, J., Cartwright, J., and Hall, B., 2005, 3D seismic interpretation of slump complexes: examples from the continental margin of Israel: Basin Research, v. 17, p. 83108.

Gamboa, D., Alves, T., and Cartwright, J., 2012, Seismic-Scale Rafted and Remnant Blocks over Salt Ridges in the Espírito Santo Basin, Brazil, in Yamada, Y., Kawamura, K., Ken Ikehara, Ogawa, Y., Urgeles, R., Mosher, D., Chaytor, J., and Strasser, M., eds., Submarine Mass Movements and Their Consequences: Dordrecht, Springer, p. 629-638.

Garzanti, E., 2017, The maturity myth in sedimentology and provenance analysis: Journal of Sedimentary Research, v. 87, p. 353-365.

Garzanti, E., and Andò, S., 2007, Heavy-mineral concentration in modern sands: implications for provenance interpretation, in Mange, M., and Wright, D., eds., Heavy Minerals in Use, Volume 58: Amsterdam, Elsevier, p. 517-545.

Garzanti, E., Andò, S., and Vezzoli, G., 2009, Grain-size dependence of sediment composition and environmental bias in provenance studies: Earth and Planetary Science Letters, v. 277, no. 3-4, p. 422-432.

Garzanti, E., Vezzoli, G., Ando, S., Paparella, P., and Clift, P. D., 2005, Petrology of Indus River sands; a key to interpret erosion history of the western Himalayan syntaxis: Earth and Planetary Science Letters, v. 229, no. 3-4, p. 287-302. DOI: 10.1016/j.eps1.2004.11.008.

Gehrels, G. E., Kapp, P., DeCelles, P., Pullen, A., Blakely, R., Weislgel, A., Ding, L., Guynn, J., Marin, A., McQuarrie, N., and Yin, A., 2011, Detrital zircon geochronology of preTertiary strata in the Tibetan-Himalayan orogen: Tectonics, v. 30, no. TC5016. doi:10.1029/2011TC002868.

Goldstein, S. L., O'Nions, R. K., and Hamilton, P. J., 1984, A Sm-Nd isotopic study of atmospheric dusts and particulates from major river systems: Earth and Planetary Science Letters, v. 70, no. 2, p. 221-236.

Goswami, V., Singh, S. K., Bhushan, R., and Rai, V. K., 2012, Temporal variations in 87Sr/86Sr and eNd in sediments of the southeastern Arabian Sea: Impact of monsoon and surface water circulation: Geochemistry Geophysics Geosystems, v. 13, no. Q01001. doi:10.1029/2011GC003802.

Gradstein, F. M., Ogg, G., and Schmitz, M., 2012, The Geologic Time Scale 2012, New York, Elsevier.

Hampton, M. A., Lee, H. J., and Locat, J., 1996, Submarine landslides: Reviews of Geophysics, v. 34, no. 1, p. 33-59. doI:10.1029/95RG03287 
1226

1227

1228

1229

1230

1231

1232

1233

1234

1235

1236

1237

1238

1239

1240

1241

1242

1243

1244

1245

1246

1247

1248

1249

1250

1251

1252

1253

1254

1255

1256

1257

1258

1259

1260

1261

1262

1263

1264

1265

1266

1267

1268

1269

1270

1271

Herron, M. M., 1988, Geochemical classification of terrigenous sands and shales from core or log data: Journal of Sedimentary Petrology, v. 58, p. 820-829.

Hine, A. C., 1992, Megabreccia shedding from modern, low-relief carbonate platforms, Nicaraguan Rise: Geological Society of America Bulletin, v. 104, p. 928-943.

Hodges, K., 2003, Geochronology and thermochronology in orogenic systems, in Rudnick, R., ed., The Crust: Amsterdam, Elsevier-Science, p. 263-292.

Honegger, K., Dietrich, V., Frank, W., Gansser, A., Thoni, M., and Trommsdorf, V. F., 1982, Magmatism and metamorphism in the Ladakh Himalayas (The Indus-Tsangpo suture zone): Earth and Planetary Science Letters, v. 60, p. 178-194.

Hsu, S.-K., Kuo, J., Lo, C.-L., Tsai, C.-H., Doo, W.-B., Ku, C.-Y., and Sibuet, J.-C., 2008, Turbidity currents, submarine landslides and the 2006 Pingtung earthquake off SW Taiwan: Terrestrial Atmospheric and Ocean Sciences, v. 19, no. 6, p. 767-772. . doi:10.3319/TAO.2008.19.6.767(PT).

Hubert, J. F., 1962, A zircon-tourmaline-rutile maturity index and the interdependence of the composition of heavy mineral assemblages with the gross composition and texture of sandstones: Journal of Sedimentary Petrology, v. 32, p. 440-450.

Inger, S., and Harris, N., 1993, Geochemical constraints on leucogranite magmatism in the Langtang Valley, Nepal Himalaya: Journal of Petrology, v. 34, no. 2, p. 345-368.

Kastens, K. A., 1984, Earthquakes as a triggering mechanism for debris flows and turbidites on the Calabrian Ridge: Marine Geology, v. 55, no. 1-2, p. 13-33.

Khan, M. A., Stern, R. J., Gribble, R. F., and Windley, B. F., 1997, Geochemical and isotopic constraints on subduction polarity, magma sources, and palaeogeography of the Kohistan intra-oceanic arc, northern Pakistan Himalaya: Journal of the Geological Society, London, v. 154, p. 935-946.

Khonde, N., Singh, S. K., Maurya, D. M., Rai, V. K., Chamyal, L. S., and Giosan, L., 2017, Tracing the Vedic Saraswati River in the Great Rann of Kachchh: Scientific Reports, v. 7, no. 5476. doi:10.1038/s41598-017-05745-8.

Klaus, A., Norris, R. D., Kroon, D., and Smit, J., 2000, Impact-induced mass wasting at the KT boundary: Blake Nose, western North Atlantic: Geology, v. 28, no. 4, p. 319-322.

Krastel, S., Wynn, R. B., Georgiopoulou, A., Geersen, J., Henrich, R. d., Meyer, M., and Schwenk, T., 2012, Large-Scale Mass Wasting on the Northwest African Continental Margin: Some General Implications for Mass Wasting on Passive Continental Margins, in Yamada, Y., Kawamura, K., Ken Ikehara, Ogawa, Y., Urgeles, R., Mosher, D., Chaytor, J., and Strasser, M., eds., Submarine Mass Movements and Their Consequences: Dordrecht, Springer, p. 189-200.

Krol, M. A., Zeitler, P. K., and Copeland, P., 1996, Episodic unroofing of the Kohistan Batholith, Pakistan: Implications from K-feldspar thermochronology: Journal of Geophysical Research-Solid Earth, v. 101, no. B12, p. $28149-28164$.

Kurian, S., Nath, B. N., Kumar, N. C., and Nair, K. K. C., 2013, Geochemical and Isotopic Signatures of Surficial Sediments from the Western Continental Shelf of India: Inferring Provenance, Weathering, and the Nature of Organic Matter Geochemical and Isotopic Signatures of Sediments From The Indian West Coast: Journal of Sedimentary Research, v. 83, no. 6, p. 427-442. doi:10.2110/jsr.2013.36.

Kusznir, N. J., Roberts, A. M., and Morley, C. K., 1995, Forward and reverse modelling of rift basin formation, in Lambiase, J. J., ed., Hydrocarbon Habitat in Rift Basins, Volume 80: London, Geological Society, p. 33-56. 
Lastras, G., Canals, M., Urgeles, R., De Batist, M., Calafat, A. M., and Casamor, J. L., 2004, Characterisation of the recent BIG'95 debris flow on the Ebro margin, Western Mediterranean Sea, after a variety of seismic reflection data: Marine Geology, v. 213, p. 235-255. doi:10.1016/j.margeo.2004.10.008.

Le Fort, P., Debon, F., and Sonet, J., 1983, Petrography, geochemistry and geochronology of some samples from the Karakoram Batholith (N. Pakistan), in Shams, F. A., ed., Granites of the Himalayas, Karakoram and Hindu Kush: Lahore, Pakistan, Punjab University, p. $377-387$.

Leynaud, D., Mienert, J., and Vanneste, M., 2009, Submarine mass movements on glaciated and non-glaciated European continental margins: A review of triggering mechanisms and preconditions to failure: Marine and Petroleum Geology, v. 26, no. 5, p. 618-632.

Li, Y., 2018, Signal propagation, provenance, and climate records in the Indus Submarine Canyon since the Last Deglacial [PhD PhD]: Louisiana State University.

Li, Y., Clift, P. D., Böning, P., Blusztajn, J., Murray, R. W., Ireland, T., Pahnke, K., and Giosan, L., 2018, Continuous Signal Propagation in the Indus Submarine Canyon since the Last Deglacial: Marine Geology, v. 406, p. 159-176. doi:10.1016/j.margeo.2018.09.011.

Lowe, D. R., 1976, Grain flow and grain flow deposits: Journal of Sedimentary Research, v. 46, no. 1.

Lucente, C. C., and Pini, G. A., 2003, Anatomy and emplacement mechanism of a large submarine slide within a Miocene foredeep in the northern Apennines, Italy: a field perspective: American Journal of Science, v. 303, p. 565-602.

Mange, M. A., and Maurer, H. F. W., 1992, Heavy minerals in colour, London, Chapman and Hall, $147 \mathrm{p}$.

Martinsen, O. J., and Bakken, B., 1990, Extensional and compressional zones in slumps and slides in the Namurian of County Clare, Ireland: Journal of the Geological Society of London, v. 147, p. 153-164.

Mienert, J., Vanneste, M., Bünz, S., Andreassen, K., Haflidason, H., and Sejrup, H. P., 2005, Ocean warming and gas hydrate stability on the mid-Norwegian margin at the Storegga Slide: Marine and Petroleum Geology, v. 22, no. 1-2, p. 233-244.

Miles, P. R., and Roest, W. R., 1993, Earliest seafoor spreading magnetic anomalies in the north Arabian Sea and the ocean-continent transition: Geophysical Journal International, v. 115, p. $1025-1031$.

Moernaut, J., De Batist, M., Charlet, F., Heirman, K., Chapron, E., Pino, M., Brümmer, R., and Urrutia, R., 2007, Giant earthquakes in South-Central Chile revealed by Holocene masswasting events in Lake Puyehue: Sedimentary Geology, v. 195, no. 3-4, p. 239-256.

Moore, D. G., 1961, Submarine slumps: Journal of Sedimentary Research, v. 31, no. 3, p. 343357.

Mullins, H. T., Gardulski, A. F., and Hine, A. C., 1986, Catastrophic collapse of the west Florida carbonate platform margin: Geology v. 14, p. 167-170.

Nair, N., and Pandey, D. K., 2018, Cenozoic sedimentation in the Mumbai Offshore Basin: Implications for tectonic evolution of the western continental margin of India: Journal of Asian Earth Sciences, v. 152, p. 132-144. doi:10.1016/j.jseaes.2017.11.037.

Najman, Y., Appel, E., Boudagher-Fadel, M., Bown, P., Carter, A., Garzanti, E., Godin, L., Han, J., Liebke, U., Oliver, G., Parrish, R., and Vezzoli, G., 2010, Timing of India-Asia collision: Geological, biostratigraphic, and palaeomagnetic constraints: Journal of Geophysical Research, v. 115, no. B12416. doi:10.1029/2010JB007673. 
Nesbitt, H. W., Markovics, G., and Price, R. C., 1980, Chemical processes affecting alkalis and alkaline earths during continental weathering: Geochimica et Cosmochimica Acta, v. 44, p. $1659-1666$.

Pandey, D. K., Clift, P. D., Kulhanek, D. K., Andò, S., Bendle, J. A. P., Bratenkov, S., Griffith, E. M., Gurumurthy, G. P., Hahn, A., Iwai, M., Khim, B.-K., Kumar, A., Kumar, A. G., Liddy, H. M., Lu, H., Lyle, M. W., Mishra, R., Radhakrishna, T., Routledge, C. M., Saraswat, R., Saxena, R., Scardia, G., Sharma, G. K., Singh, A. D., Steinke, S., Suzuki, K., Tauxe, L., Tiwari, M., Xu, Z., and Yu, Z., 2016a, Site U1456, in Pandey, D. K., Clift, P. D., and Kulhanek, D. K., eds., Arabian Sea Monsoon. Proceedings of the International Ocean Discovery Program, Volume 355: College Station, TX, International Ocean Discovery Program.

-, 2016b, Site U1457, in Pandey, D. K., Clift, P. D., and Kulhanek, D. K., eds., Arabian Sea Monsoon. Proceedings of the International Ocean Discovery Program, Volume 355: College Station, TX, International Ocean Discovery Program.

Pandey, D. K., Clift, P. D., Kulhanek, D. K., and Expedition 355 Scientists, 2016c, Arabian Sea Monsoon: Proceedings of the International Ocean Discovery Program, v. 355. doi:10.14379/iodp.proc.355.2016.

Pandey, O. P., Agrawal, P. K., and Negi, J. G., 1995, Lithospheric structure beneath Laxmi Ridge and late Cretaceous geodynamic events: Geo-Marine Letters, v. 15, p. 85-91.

Parnell, J., 2008, Global mass wasting at continental margins during Ordovician high meteorite influx: Nature Geoscience, v. 2, p. 57. doi:10.1038/ngeo386.

Parrish, R. R., and Hodges, K. V., 1996, Isotopic constraints on the age and provenance of the Lesser and Greater Himalayan sequences, Nepalese Himalaya: Geological Society of America Bulletin, v. 108, no. 7, p. 904-911.

Parrish, R. R., and Tirrul, R., 1989, U-Pb age of the Baltoro Granite, Northwest Himalaya, and implications for monazite U-Pb systematics: Geology, v. 17, p. 1076-1079.

Peters, S. E., and Loss, D. P., 2012, Storm and fair-weather wave base: A relevant distinction?: Geology, v. 40, no. 6, p. 511-514.

Pickering, K., Stow, D., Watson, M., and Hiscott, R., 1986, Deep-water facies, processes and models: a review and classification scheme for modern and ancient sediments: EarthScience Reviews, v. 23, no. 2, p. 75-174.

Piper, D. J., Shor, A. N., Farre, J. A., O'Connell, S., and Jacobi, R., 1985, Sediment slides and turbidity currents on the Laurentian Fan: Sidescan sonar investigations near the epicenter of the 1929 Grand Banks earthquake: Geology, v. 13, no. 8, p. 538-541.

Principaud, M., Mulder, T., Gillet, H., and Borgomano, J., 2015, Large-scale carbonate submarine mass-wasting along the northwestern slope of the Great Bahama Bank (Bahamas): Morphology, architecture, and mechanisms: Sedimentary Geology, v. 317, p. 27-42. doi:10.1016/j.sedgeo.2014.10.008.

Rao, R. P., and Talukdar, S. N., 1980, Petroleum geology of Bombay High field, India, in Halbouty, M. T., ed., Giant oil and gas fields of the decade: 1968-1978, Volume 30, American Association of Petroleum Geologists, p. 487-506.

Rao, V. P., and Rao, B. R., 1995, Provenance and distribution of clay minerals in the sediments of the western continental shelf and slope of India: Continental Shelf Research, v. 15, no. 14, p. 1757-1771. doi:10.1016/0278-4343(94)00092-2. 
1362

1363

1364

1365

1366

1367

1368

1369

1370

1371

1372

1373

1374

1375

1376

1377

1378

1379

1380

1381

1382

1383

1384

1385

1386

1387

1388

1389

1390

1391

1392

1393

1394

1395

1396

1397

1398

1399

1400

1401

1402

1403

1404

1405

1406

Ravikant, V., Wu, F. Y., and Ji, W. Q., 2009, Zircon U-Pb and Hf isotopic constraints on petrogenesis of the Cretaceous-Tertiary granites in eastern Karakoram and Ladakh, India: Lithos, v. 110, p. 153-166.

Rolland, Y., Picard, C., Pecher, A., Lapierre, H., Bosch, D., and Keller, F., 2002, The Cretaceous Ladakh arc of NW himalaya — slab melting and melt-mantle interaction during fast northward drift of Indian Plate: Chemical Geology, v. 182, p. 139-178.

Schärer, U., Copeland, P., Harrison, T. M., and Searle, M. P., 1990, Age, cooling history, and origin of post-collisional leucogranites in the Karakoram Batholith; a multi-system isotope study: The Journal of Geology, v. 98, no. 2, p. 233-251.

Schärer, U., Xu, R.-H., and Allègre, C. J., 1984, U-Pb geochronology of Gangdese (Transhimalaya) plutonism in the Lhasa-Xigaze region, Tibet: Earth and Planetary Science Letters, v. 69, no. 2, p. 311-320.

Schlager, W., Reijmer, J. J. G., and Droxler, A., 1994, Highstand shedding of carbonate platforms: Journal of Sedimentary Research, v. 64, no. 3b, p. 270-281. doi:10.1306/D4267FAA-2B26-11D7-8648000102C1865D.

Sclater, J. G., and Christie, P. A. F., 1980, Continental stretching: an explanation of the post Mid-Cretaceous subsidence of the central North Sea basin: Journal of Geophysical Research, v. 85, p. 3711-3739.

Seilacher, A., 1967, Bathymetry of trace fossils: Marine Geology, v. 5, p. 413-428.

Singh, M., Sharma, M., and Tobschall, H. J., 2005, Weathering of the Ganga alluvial plain, northern India: implications from fluvial geochemistry of the Gomati River: Applied Geochemistry, v. 20, p. 1-21.

Singh, S., Kumar, R., Barley, M. E., and Jain, A. K., 2007, SHRIMP U-Pb ages and depth of emplacement of Ladakh batholith, eastern Ladakh, India: Journal of Asian Earth Sciences, v. 30, no. 3, p. 490-503.

Singh, S. K., and France-Lanord, C., 2002, Tracing the distribution of erosion in the Brahmaputra watershed from isotopic compositions of stream sediments: Earth and Planetary Science Letters, v. 202, no. 3-4, p. 645-662.

Strachan, L. J., 2002, Slump-initiated and controlled syndepositional sandstone remobilisation: an example from the Namurian of County Clare, Ireland: Sedimentology, v. 49, p. 25-41.

Talling, P. J., Masson, D. G., Sumner, E. J., and Malgesini, G., 2012, Subaqueous sediment density flows: Depositional processes and deposit types: Sedimentology, v. 59, no. 7, p. 1937-2003.

Tappin, D. R., Watts, P., McMurtry, G. M., Lafoy, Y., and Matsumoto, T., 2001, The Sissano, Papua New Guinea tsunami of July 1998 - offshore evidence on the source mechanism: Marine Geology, v. 17, p. 1-23.

Trincardi, F., and Argnani, A., 1990, Gela Submarine slide: a major basin-wide event in the PlioQuatemary foredeep of Sicily: Geo-marine Letters, v. 10, p. 13-21.

Vardy, M. E., Pinson, L. J., Bull, J. M., Dix, J. K., Henstock, T. J., Davis, J. W., and Gutowski, M., 2010, 3D seismic imaging of buried Younger Dryas mass movement flows: Lake Windermere, UK: Geomorphology, v. 118, no. 1-2, p. 176-187.

Vermeesch, P., 2004, How many grains are needed for a provenance study?: Earth and Planetary Science Letters, v. 224, p. 351-441.

Wandrey, C. J., 2004, Bombay Geologic Province Eocene to Miocene Composite Total Petroleum System, India: US Geological Survey, Department of the Interior, 2208-F. 
Weinberg, R. F., and Dunlap, W. J., 2000, Growth and Deformation of the Ladakh Batholith, Northwest Himalayas: Implications for Timing of Continental Collision and Origin of Calc-Alkaline Batholiths: Journal of Geology, v. 108, p. 303-320. DOI: 10.1086/314405. Yamada, Y., Kawamura, K., Ikehara, K., Ogawa, Y., Urgeles, R., Mosher, D., Chaytor, J., and Strasser, M., 2012, Submarine mass movements and their consequences, in Lykousis, V., Sakellariou, D., and Locat, J., eds., Submarine mass movements and their consequences, Springer, p. 1-12.

Zeilinger, G., Burg, J. P., Schaltegger, U., and Seward, D., 2001, New U/ Pb and fission track ages and their implication for the tectonic history of the lower Kohistan Arc Complex, northern Pakistan: Journal of Asian Earth Sciences, v. 19, no. 3S, p. 79-81.

Zeitler, P. K., and Chamberlain, C. P., 1991, Petrogenetic and Tectonic Significance of Young Leukogranites from the Northwestern Himalaya, Pakistan: Tectonics, v. 10, no. 4, p. 729 741.

Zeitler, P. K., Chamberlain, C. P., and Smith, H. A., 1993, Synchronous Anatexis, Metamorphism, and Rapid Denudation at Nanga-Parbat (Pakistan Himalaya): Geology, v. 21, no. 4, p. 347-350.

Zhuang, G., Najman, Y., Guillot, S., Roddaz, M., Antoine, P.-O., Métaise, G., Carter, A., Marivaux, L., and Solangig, S. H., 2015, Constraints on the collision and the pre-collision tectonic configuration between India and Asia from detrital geochronology, thermochronology, and geochemistry studies in the lower Indus basin, Pakistan: Earth and Planetary Science Letters, v. 432, p. 363-373. doi:10.1016/j.eps1.2015.10.026. 


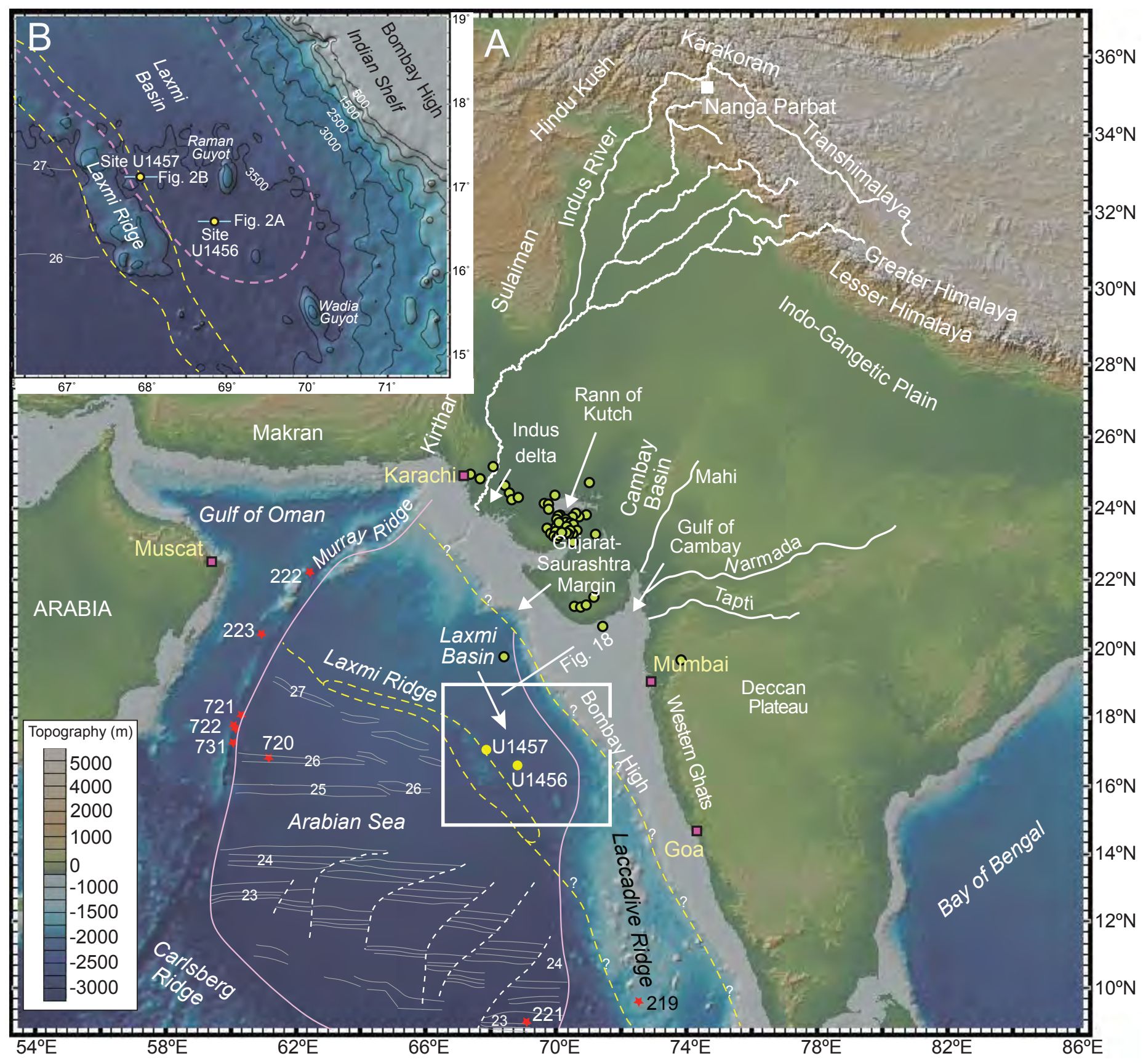

Figure 1

Dailey et al. 
(A) Site U1456
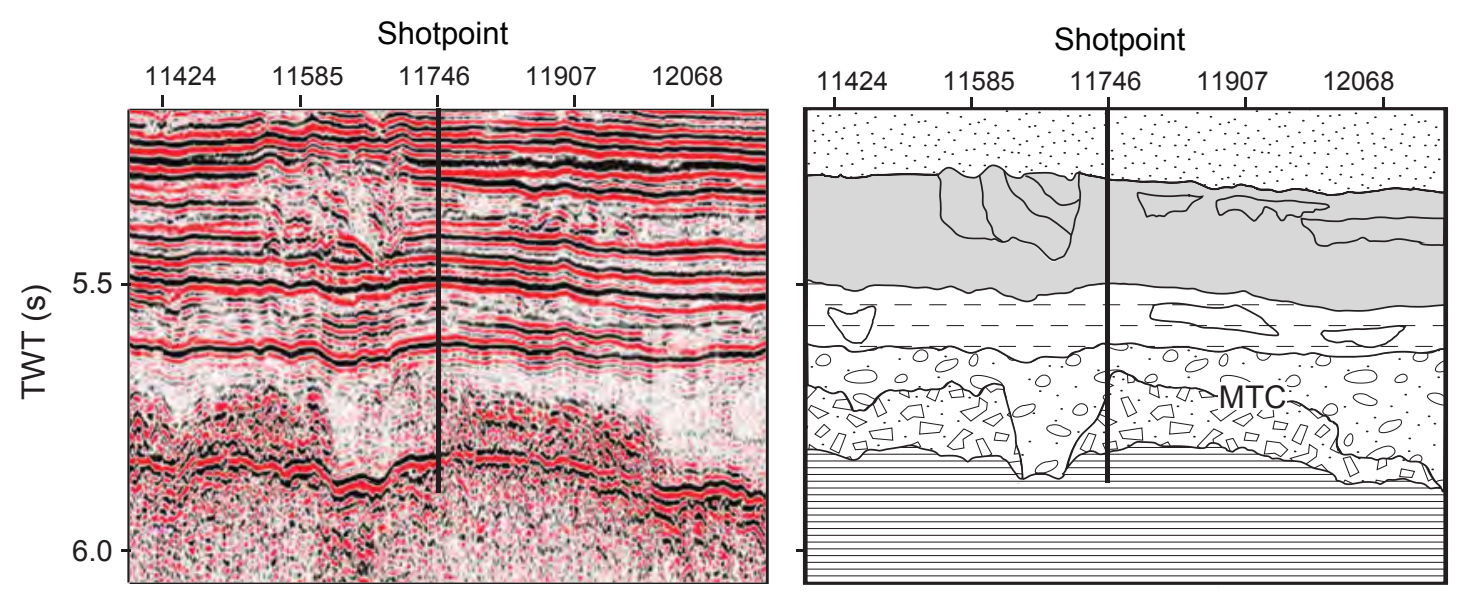

(B) Site U1457
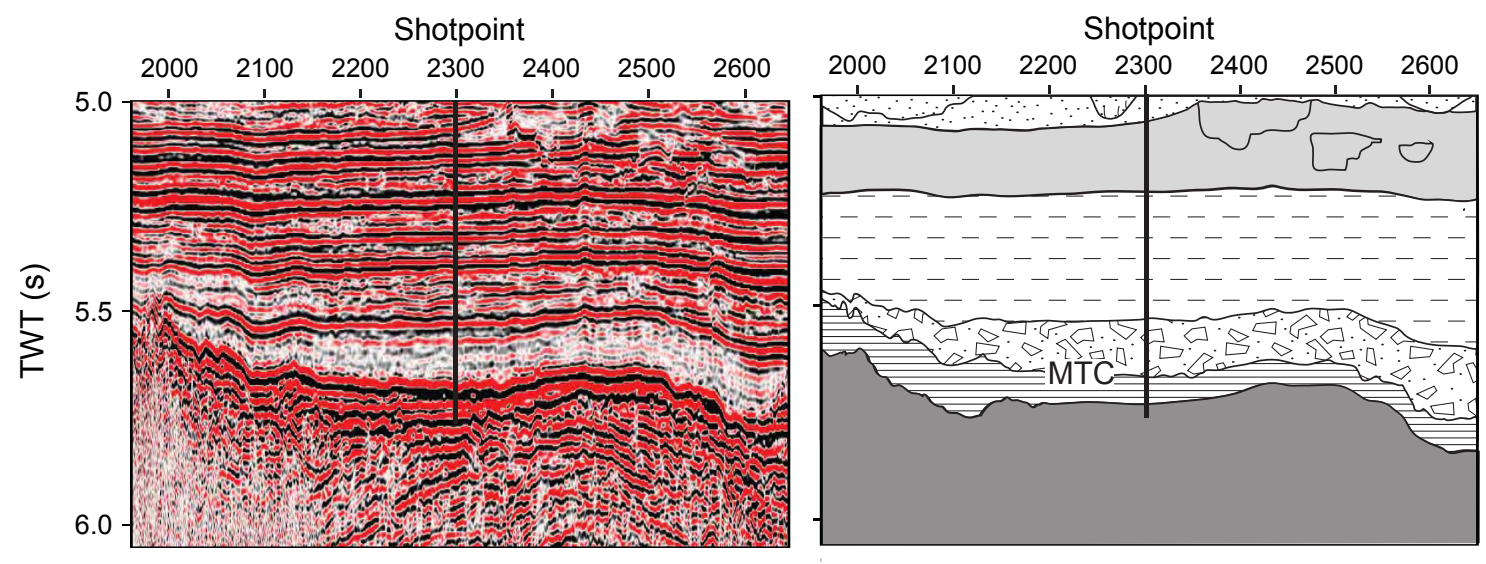

\begin{tabular}{|llll|}
\hline Livi) & Lower Pleistocene & MTC Phase 2 (Nataraja Slide) \\
$\square$ & Pliocene & MTC Phase 1 (Nataraja Slide) \\
$\square$ & Upper Miocene-Pliocene & Paleocene-Middle Miocene \\
\hline- & Upper Miocene & Basement \\
\hline
\end{tabular}

Figure 2

Dailey et al. 
(A) Site U1456

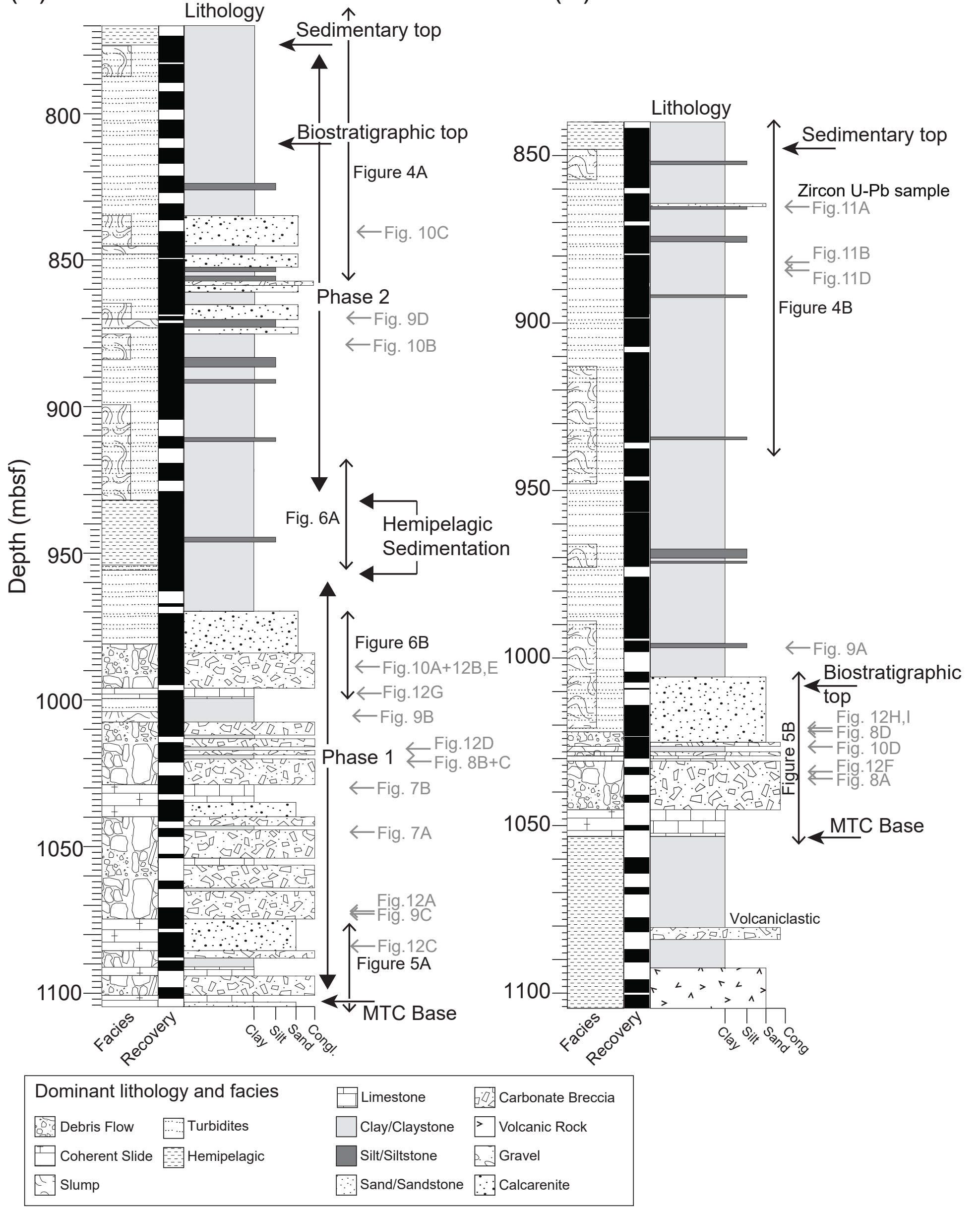




\section{(A) Site U1456}

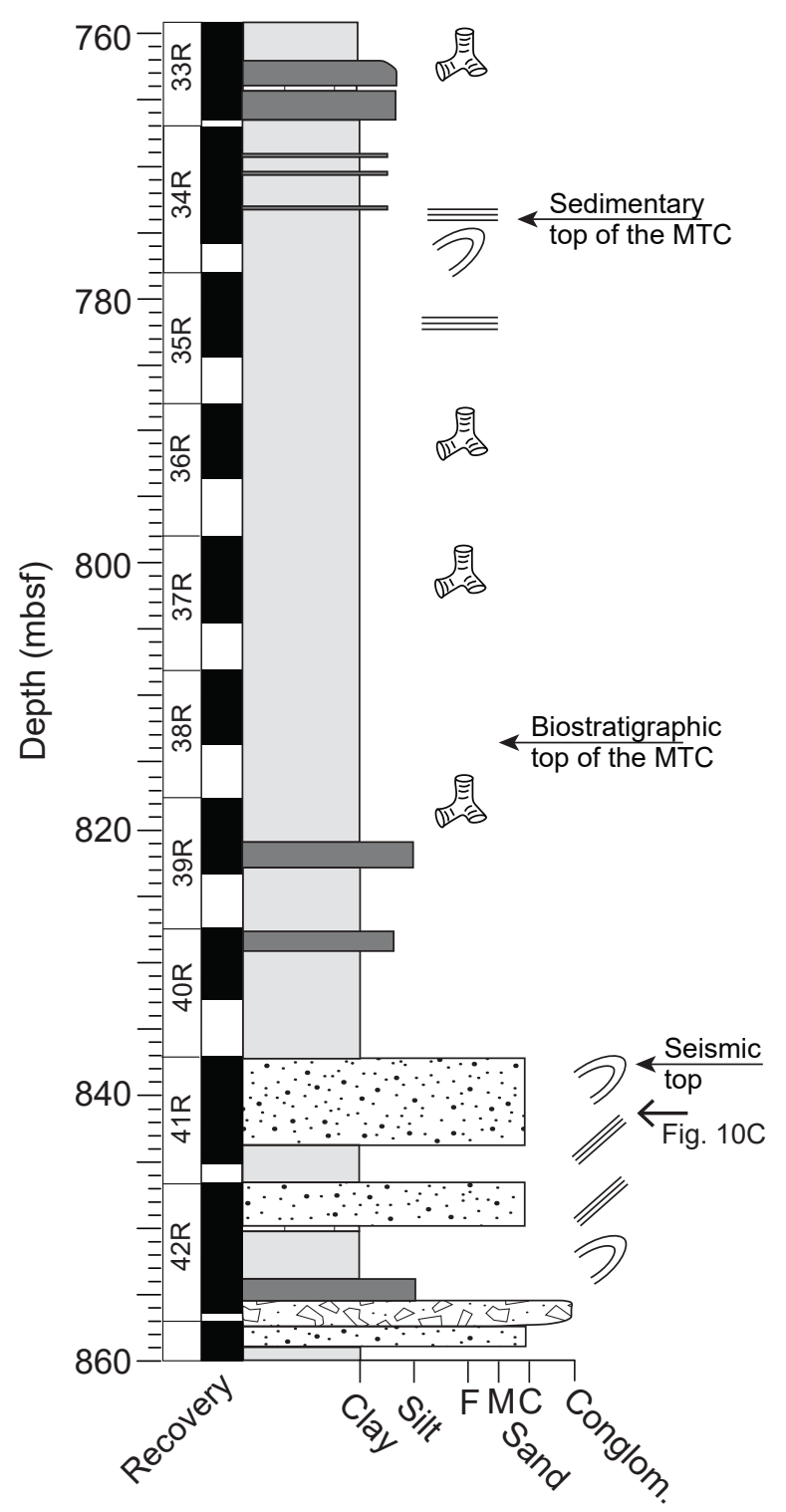

(B) Site U1457

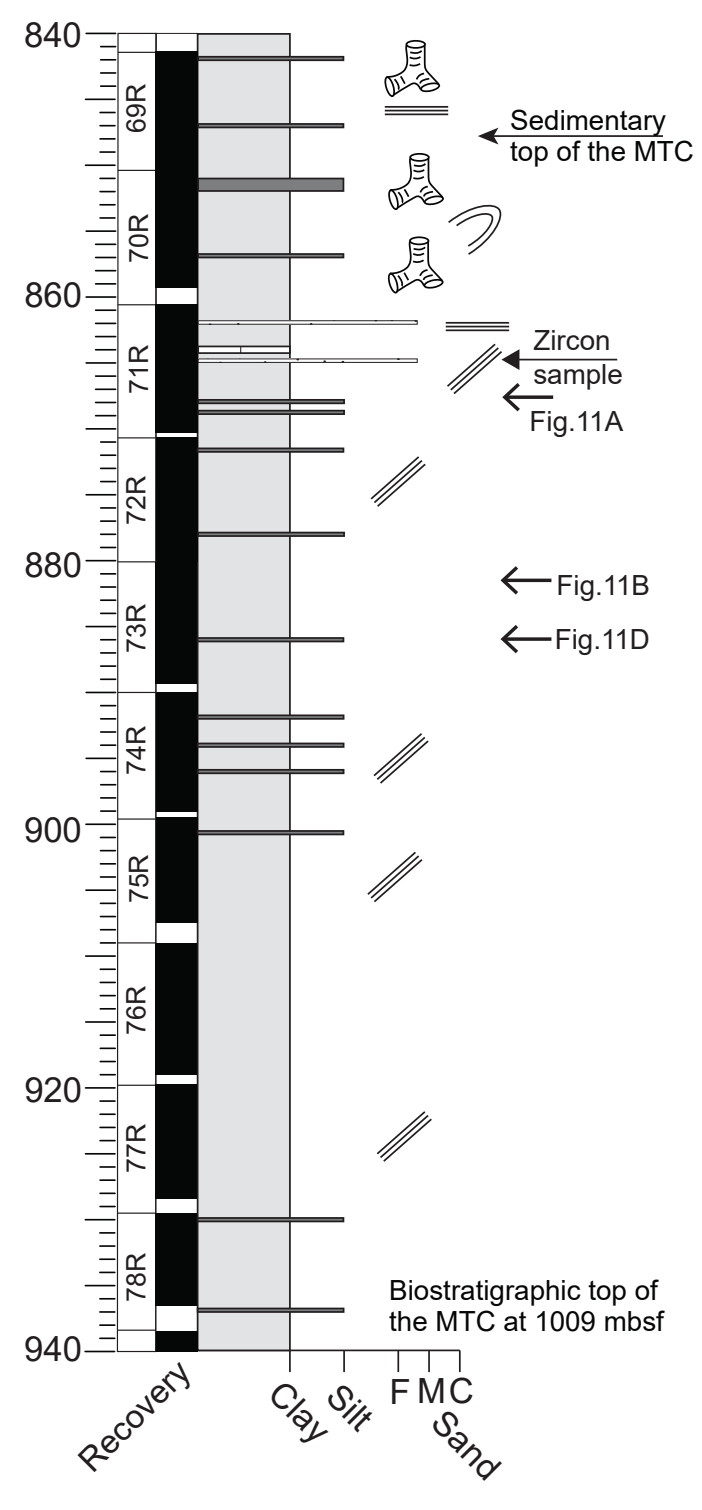

\begin{tabular}{|c|c|c|c|}
\hline \multicolumn{4}{|c|}{ Lithology and sedimentary structures } \\
\hline$\square$ Carbonate ooze/stone & $\because$ Calcarenite & $\bar{\equiv}$ Parallel Laminations & Slump Fold \\
\hline Clay/Claystone & Breccia & $\Leftrightarrow$ Burrows & \/ Small Scale Fault \\
\hline Silt/Siltstone & Sand/Sandstone & $\sim$ Wavy Laminations & $\mathscr{H} /$ Tilted Bedding \\
\hline
\end{tabular}

Figure 4 Dailey et al. 


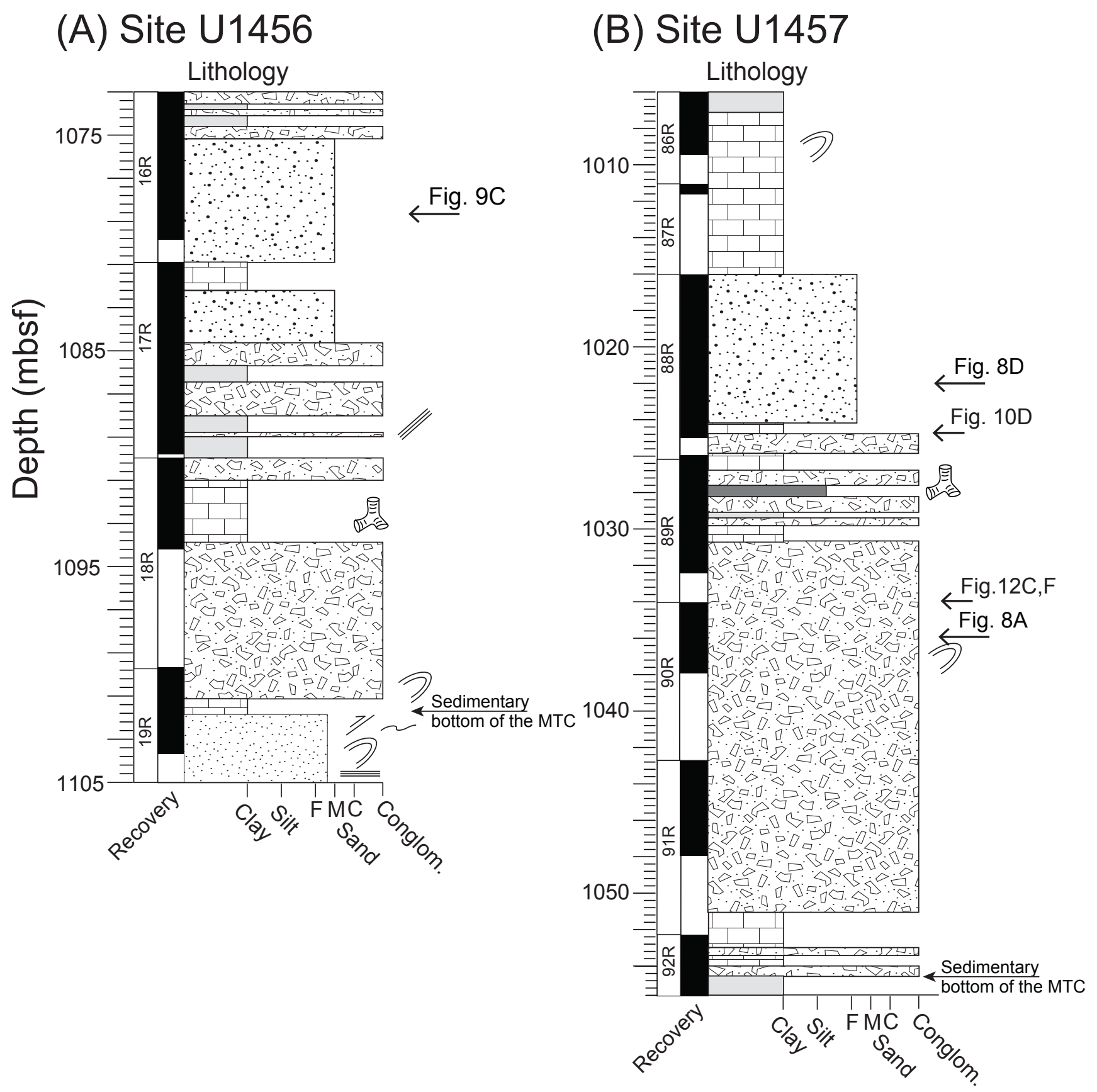

Figure 5

Dailey et al. 
(A) Site U1456

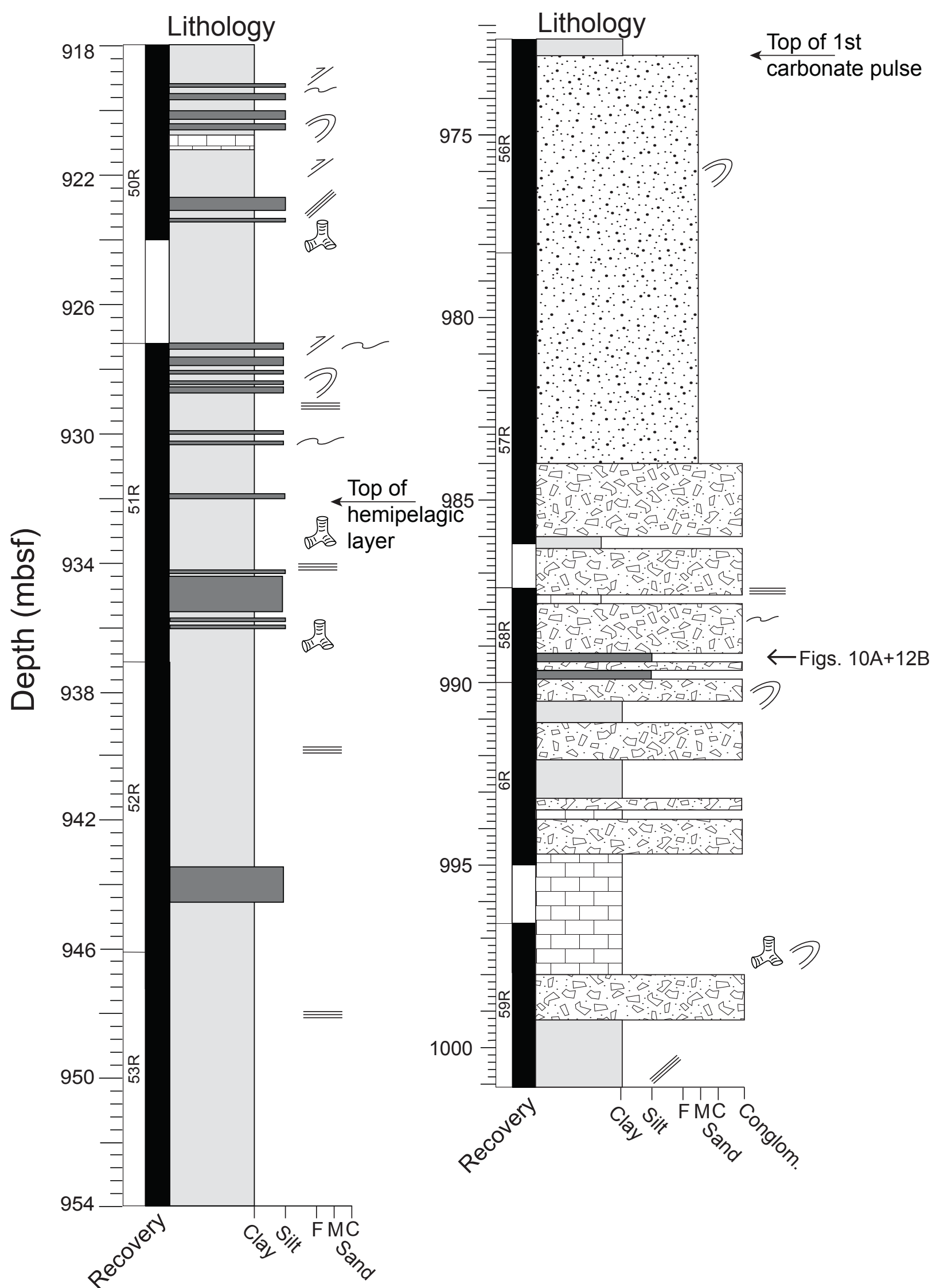

(B) Site U1456

Figure 6

Dailey et al. 
(A)

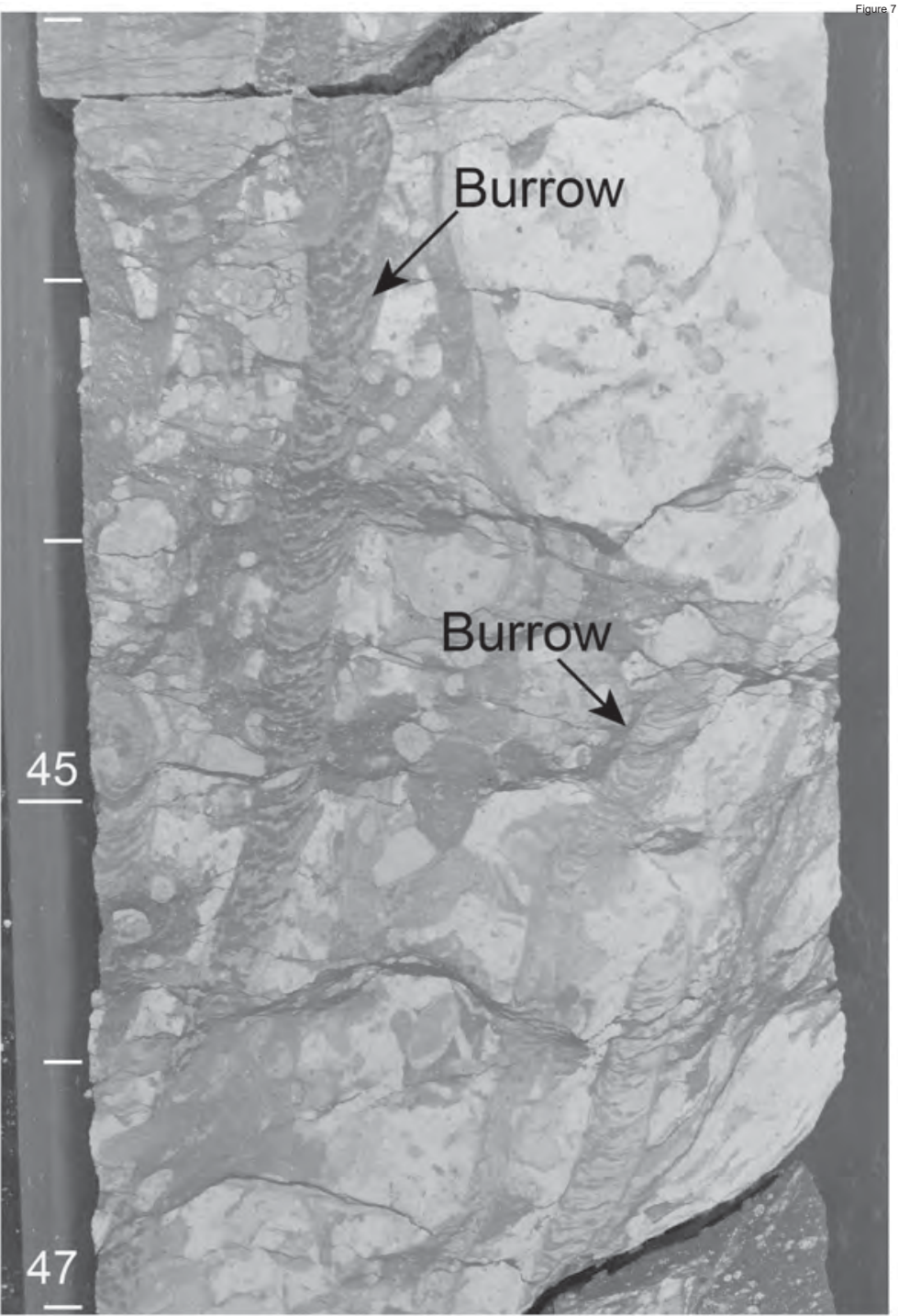

(B)

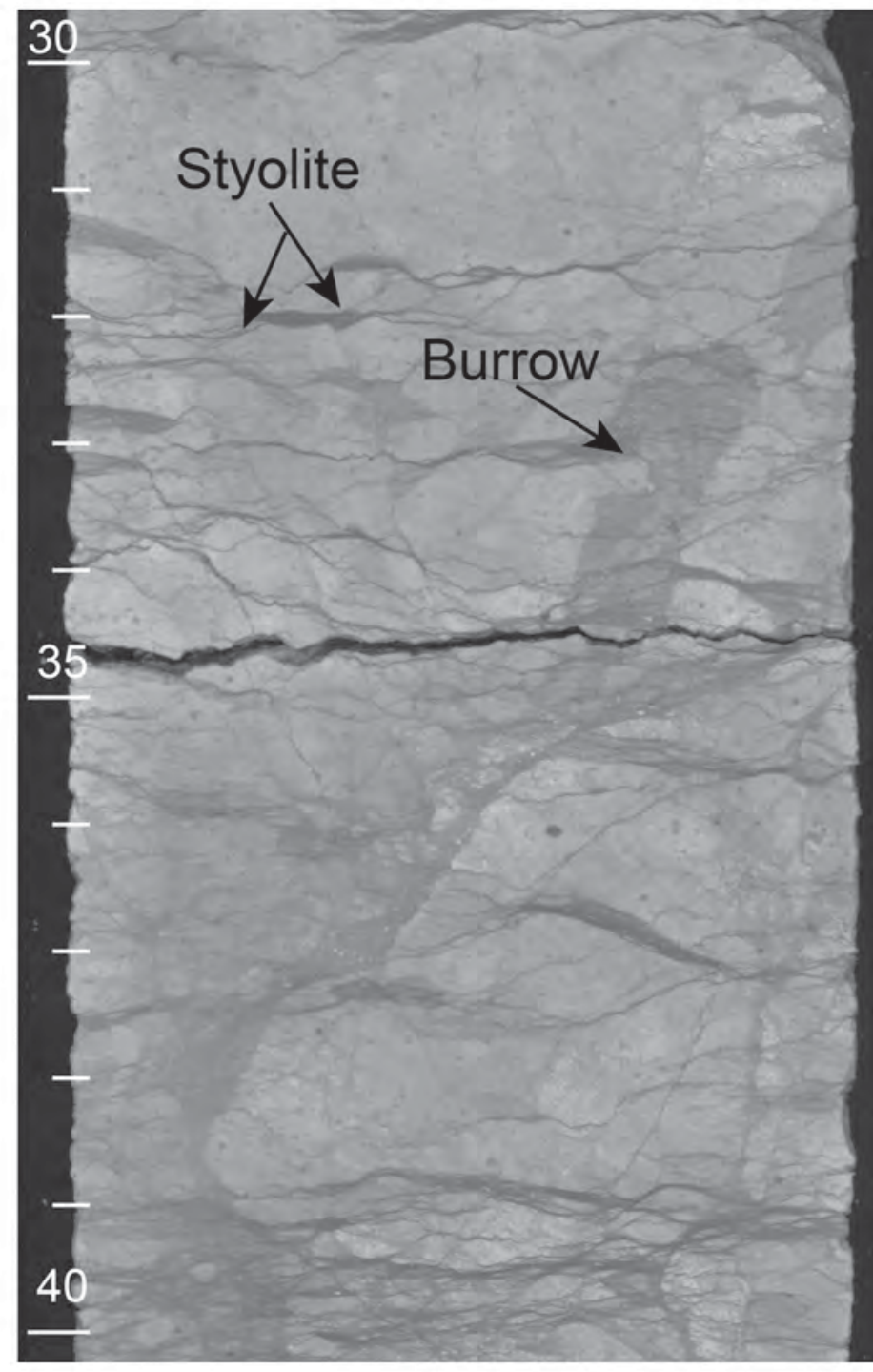

Figure 7 Dailey et al. 


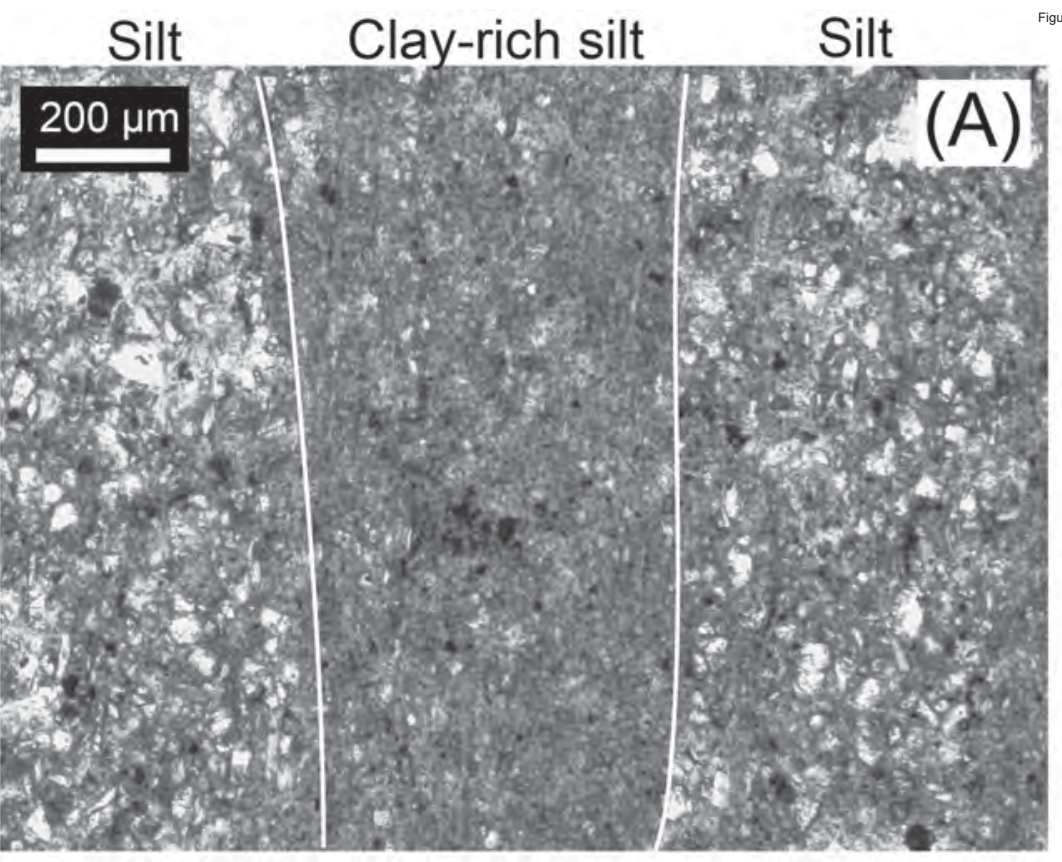

Calcite grains

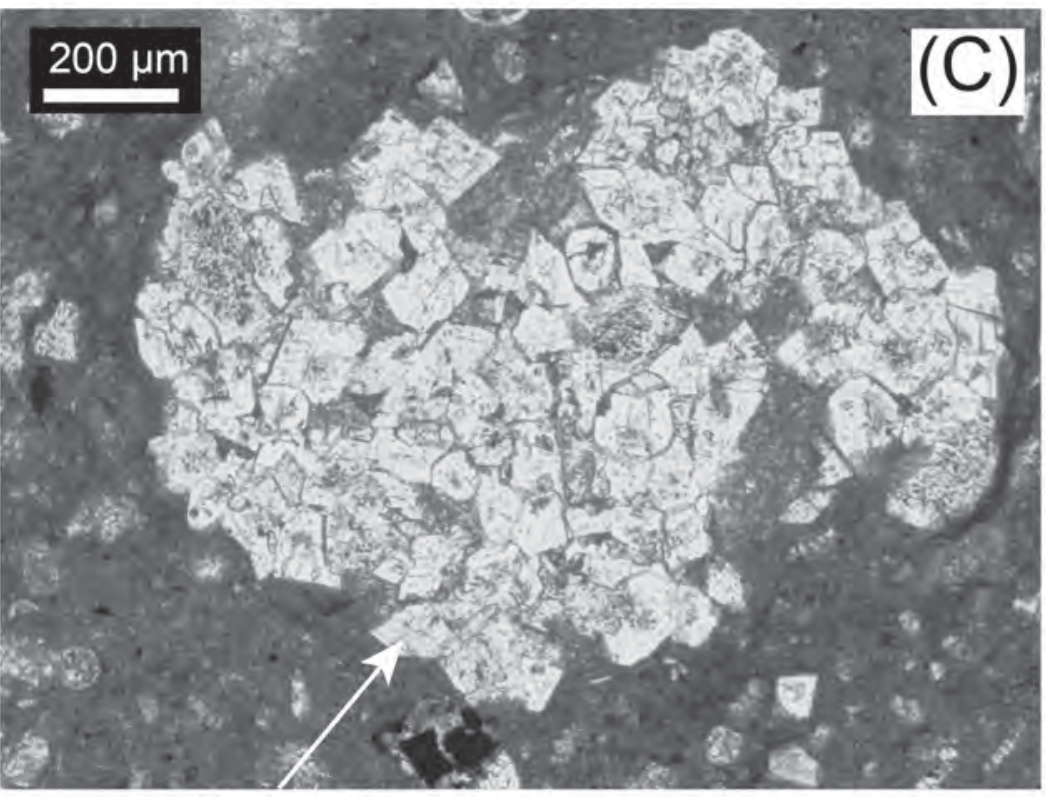

Dolomite
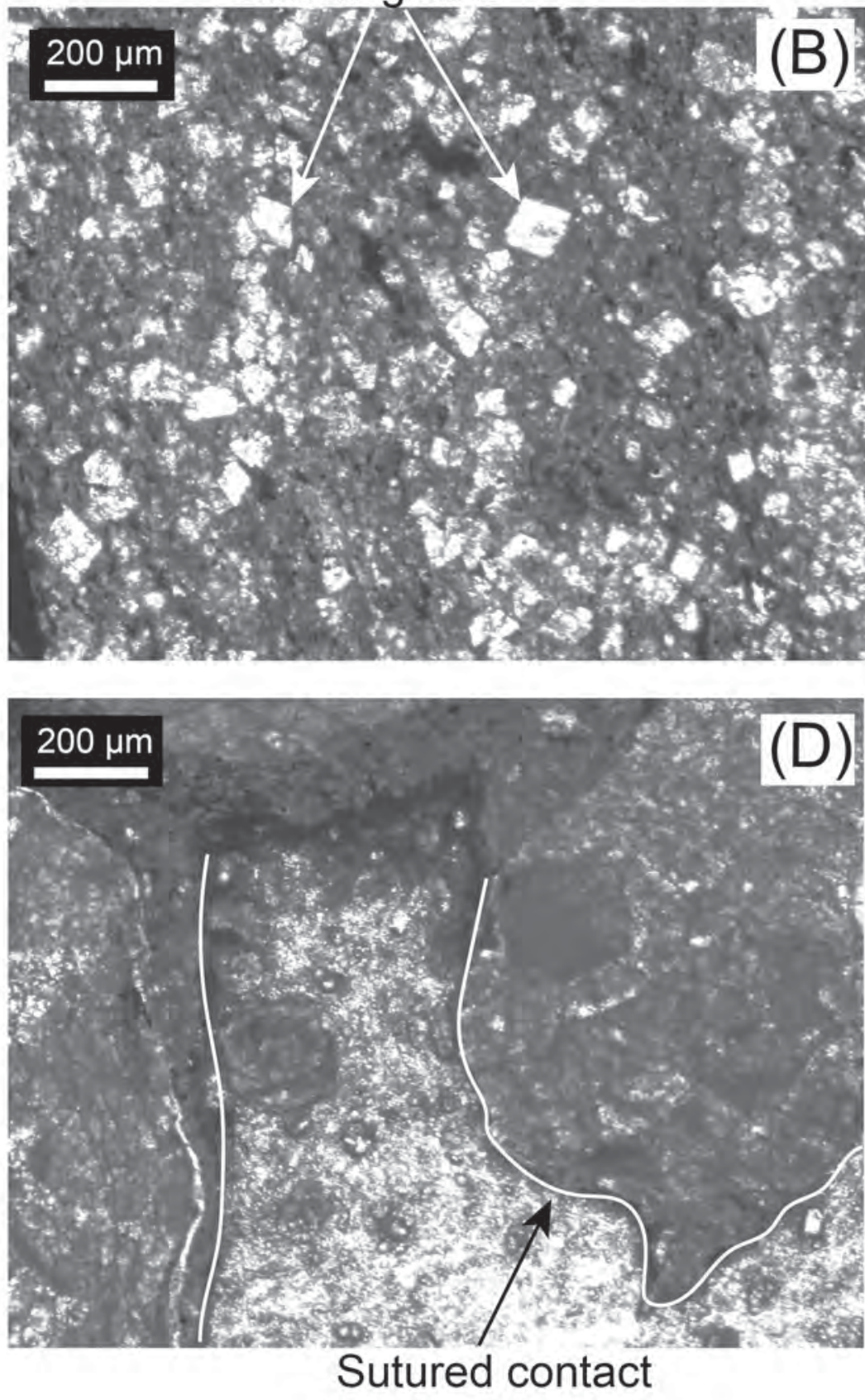

Figure 9

Dailey et al. 
(A)

$\underline{45}$

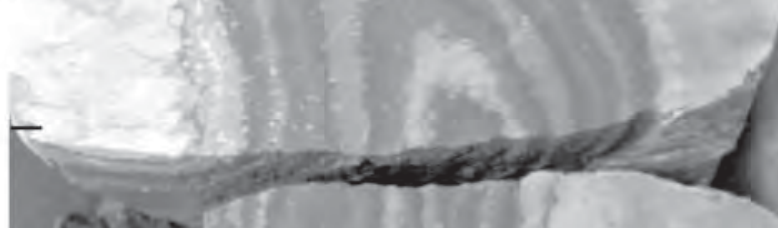

(C

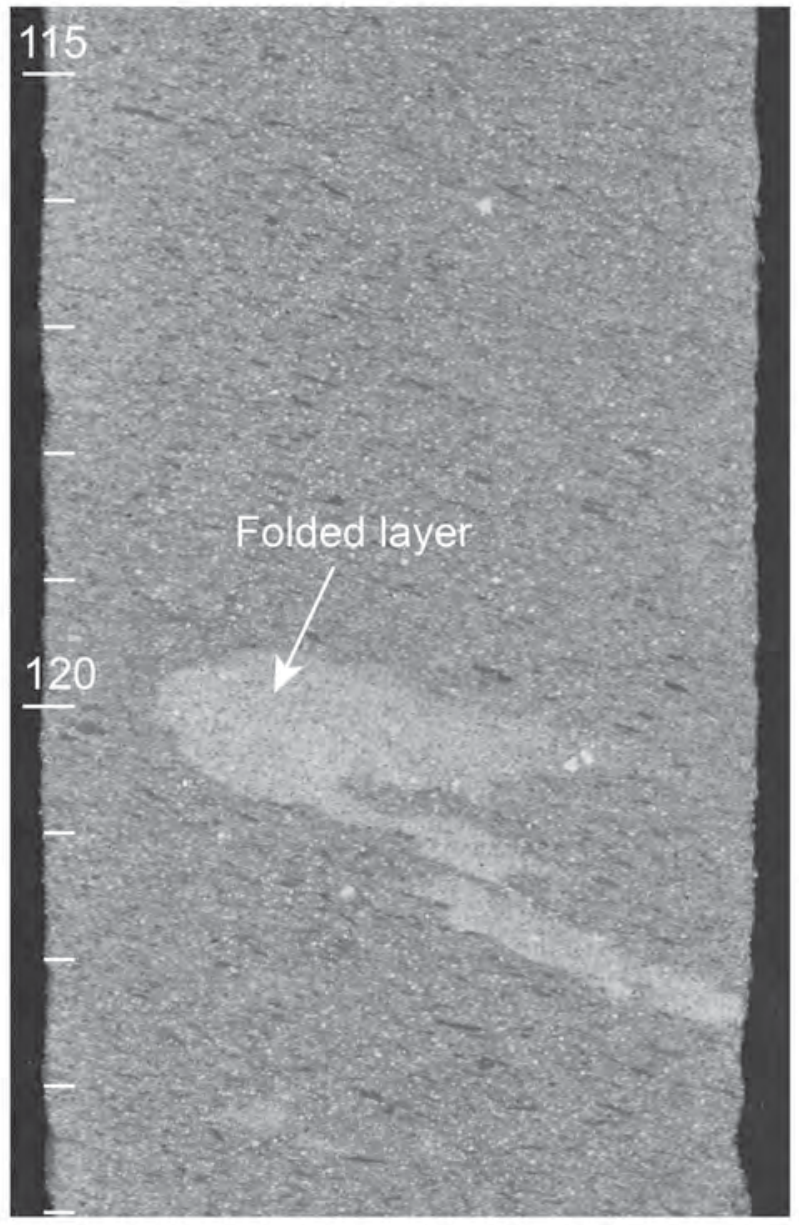

50
(B)

(D)

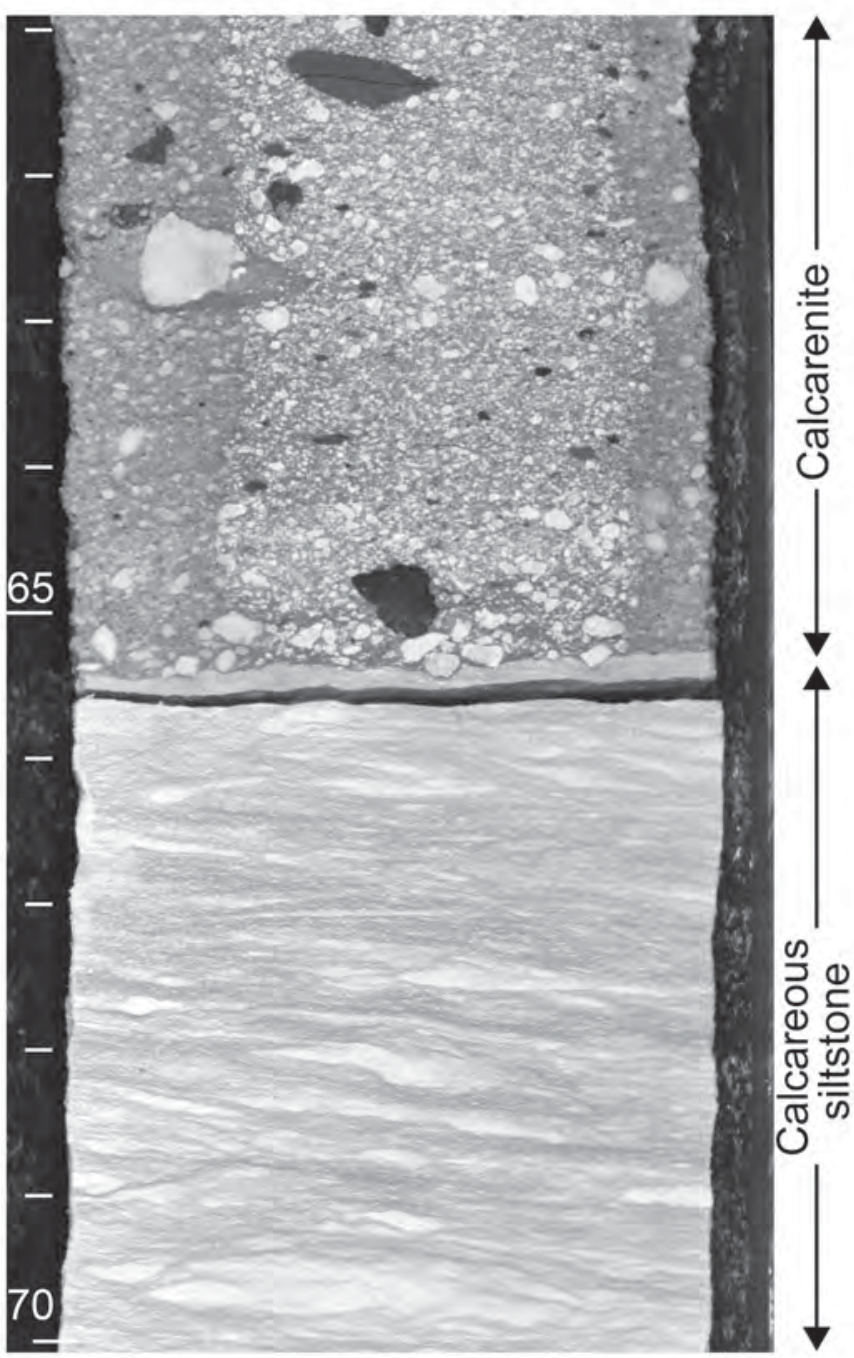

Figure 10 Dailey et al. 
(B) $\overline{140}$

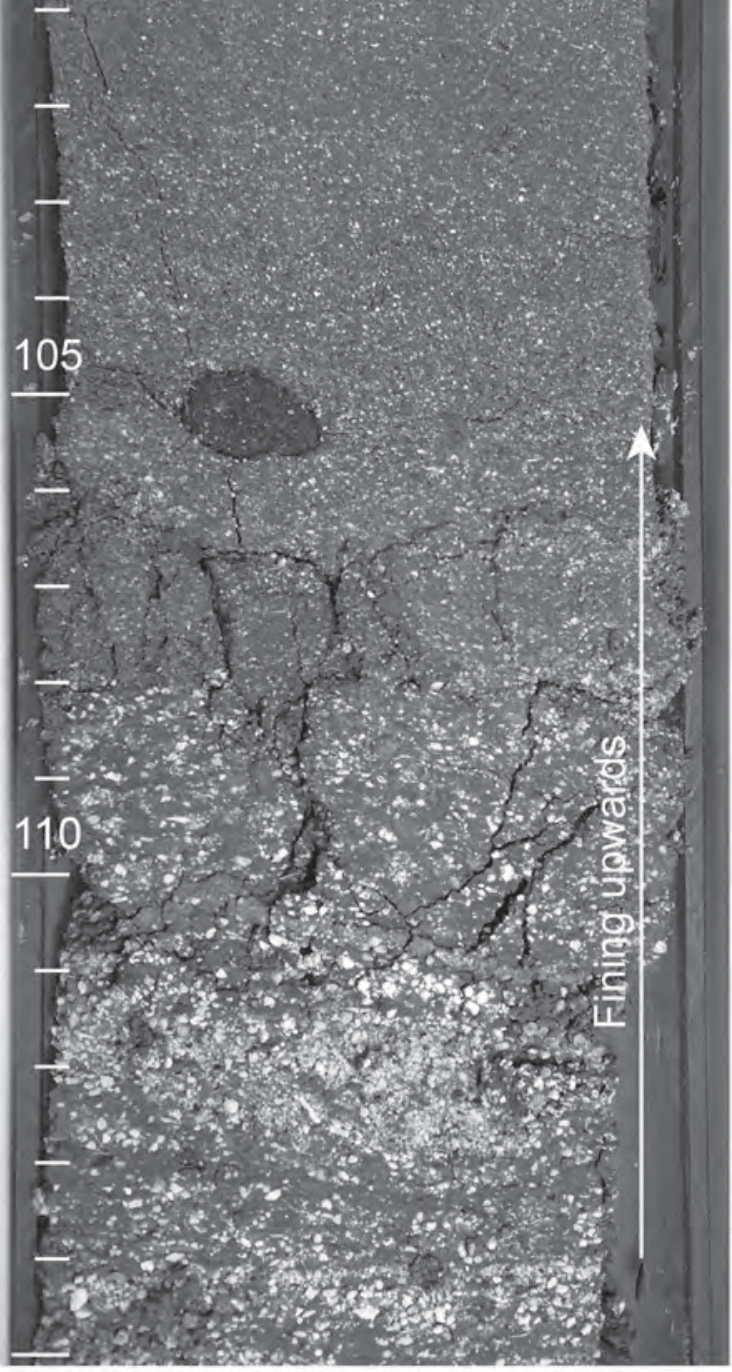

(C)

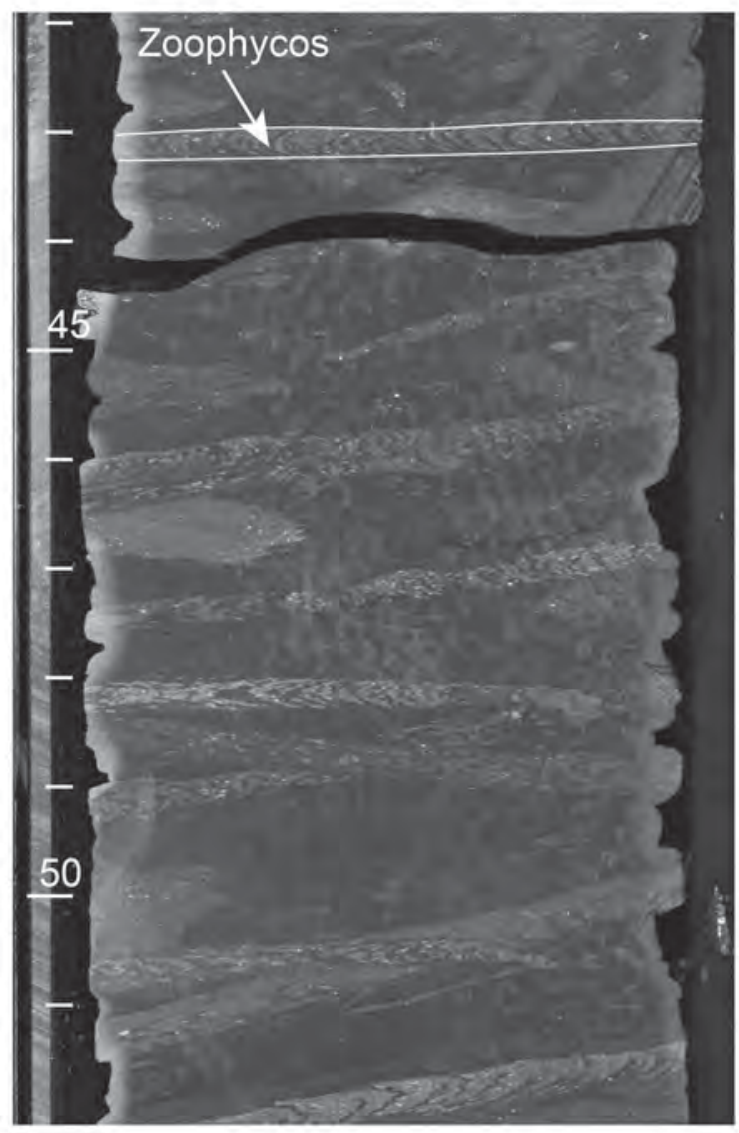

Figure 11

Dailey et al. 

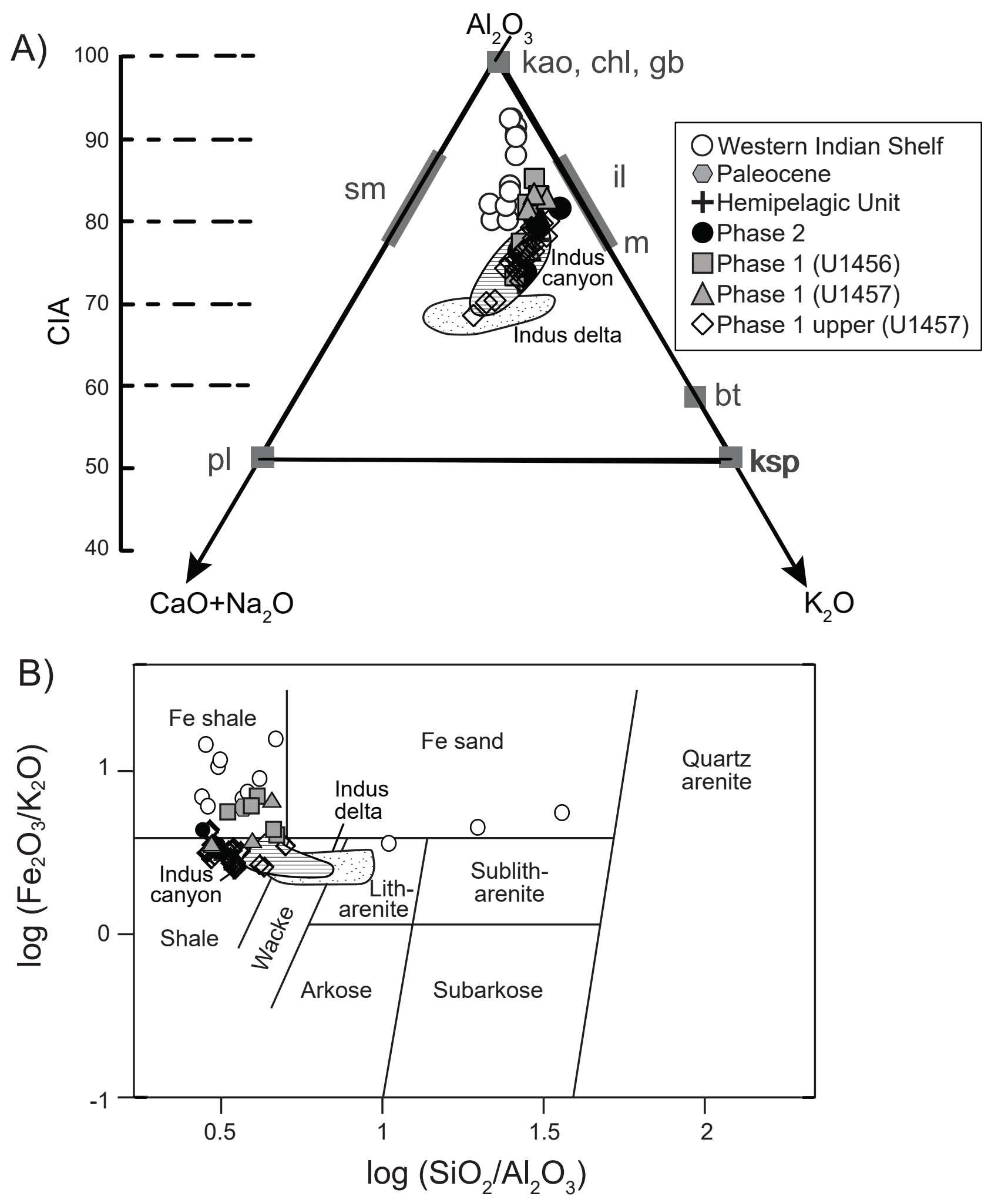

Figure 13 


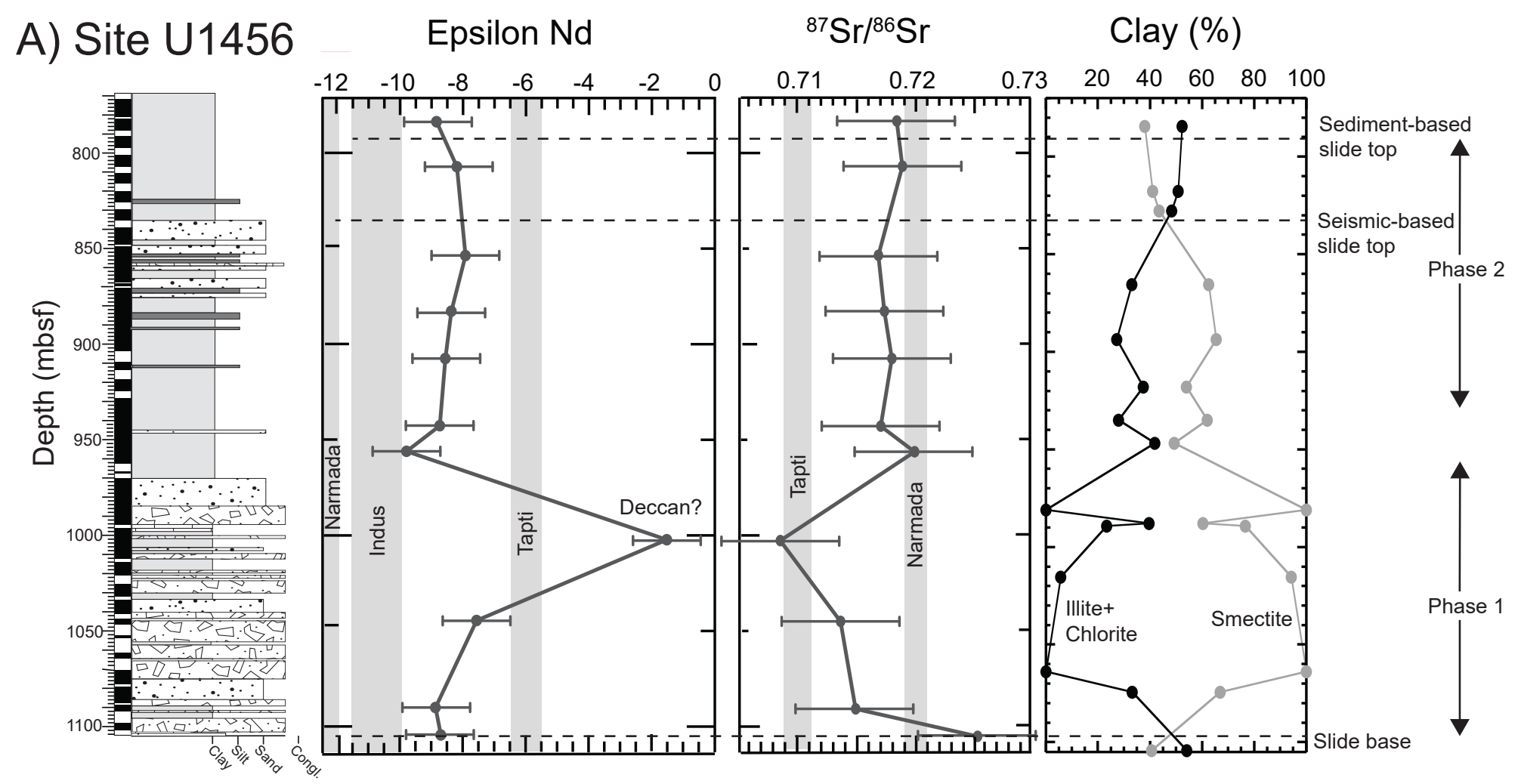

B) Site U1457

Epsilon Nd

${ }^{87} \mathrm{Sr} /{ }^{86} \mathrm{Sr}$

Clay (\%)

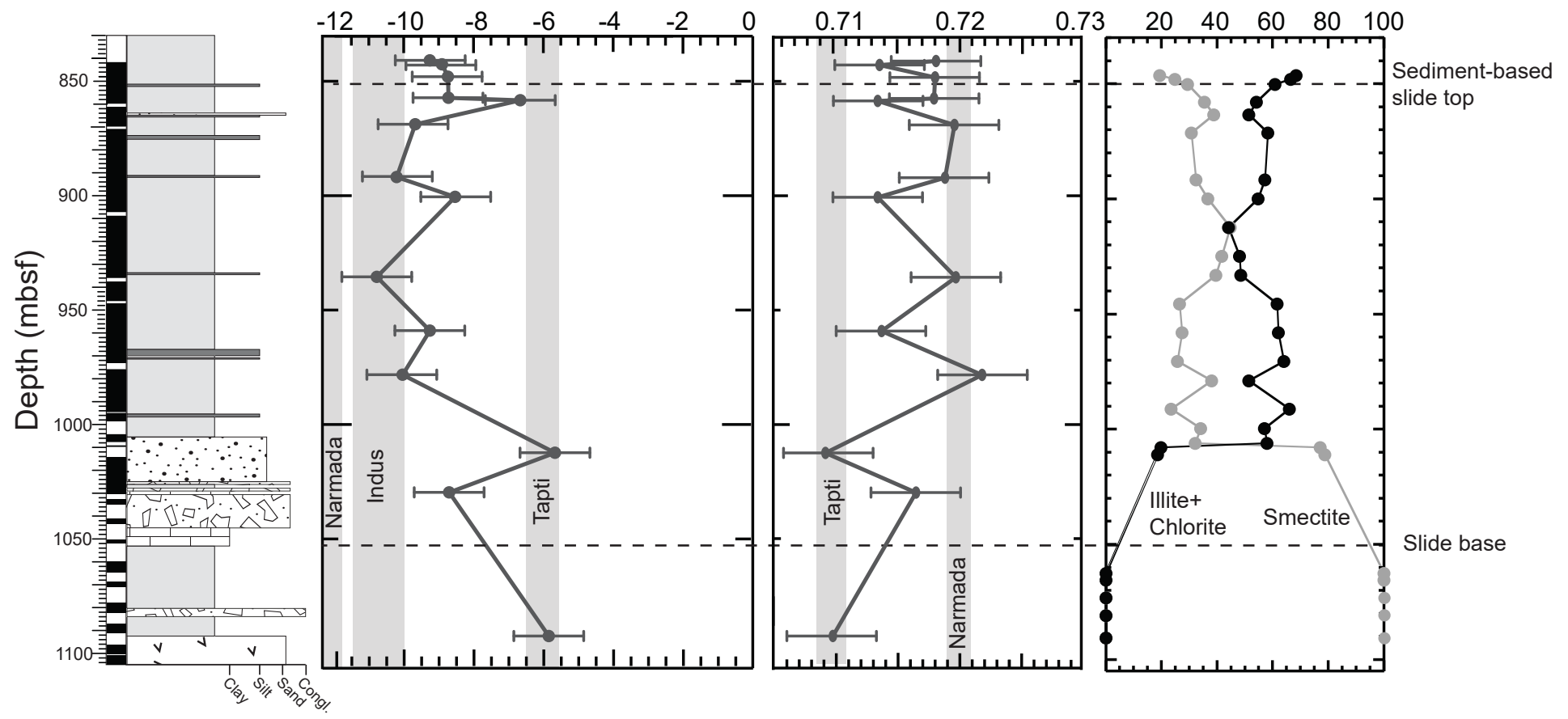

Figure 14 


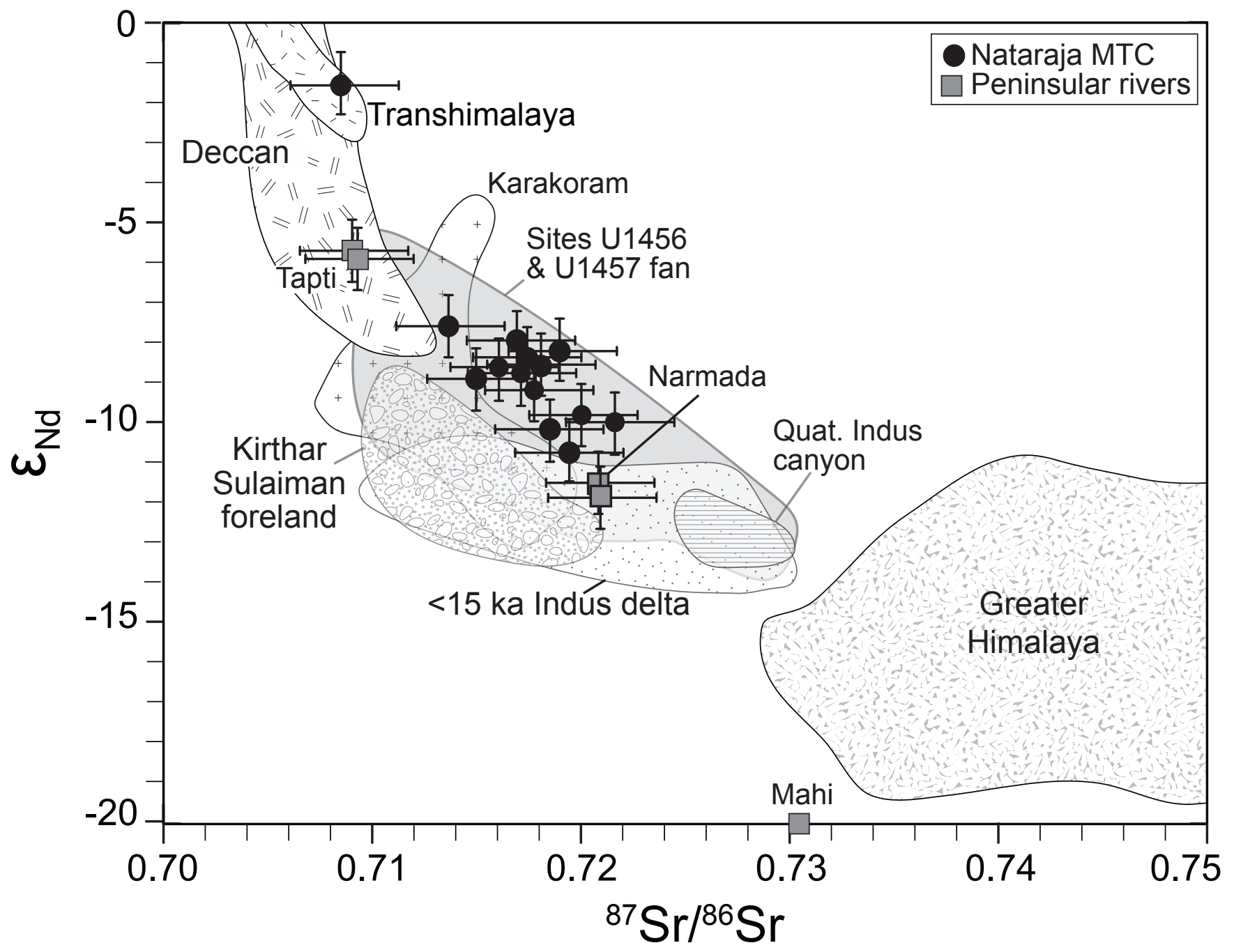

Figure 15 Dailey et al. 


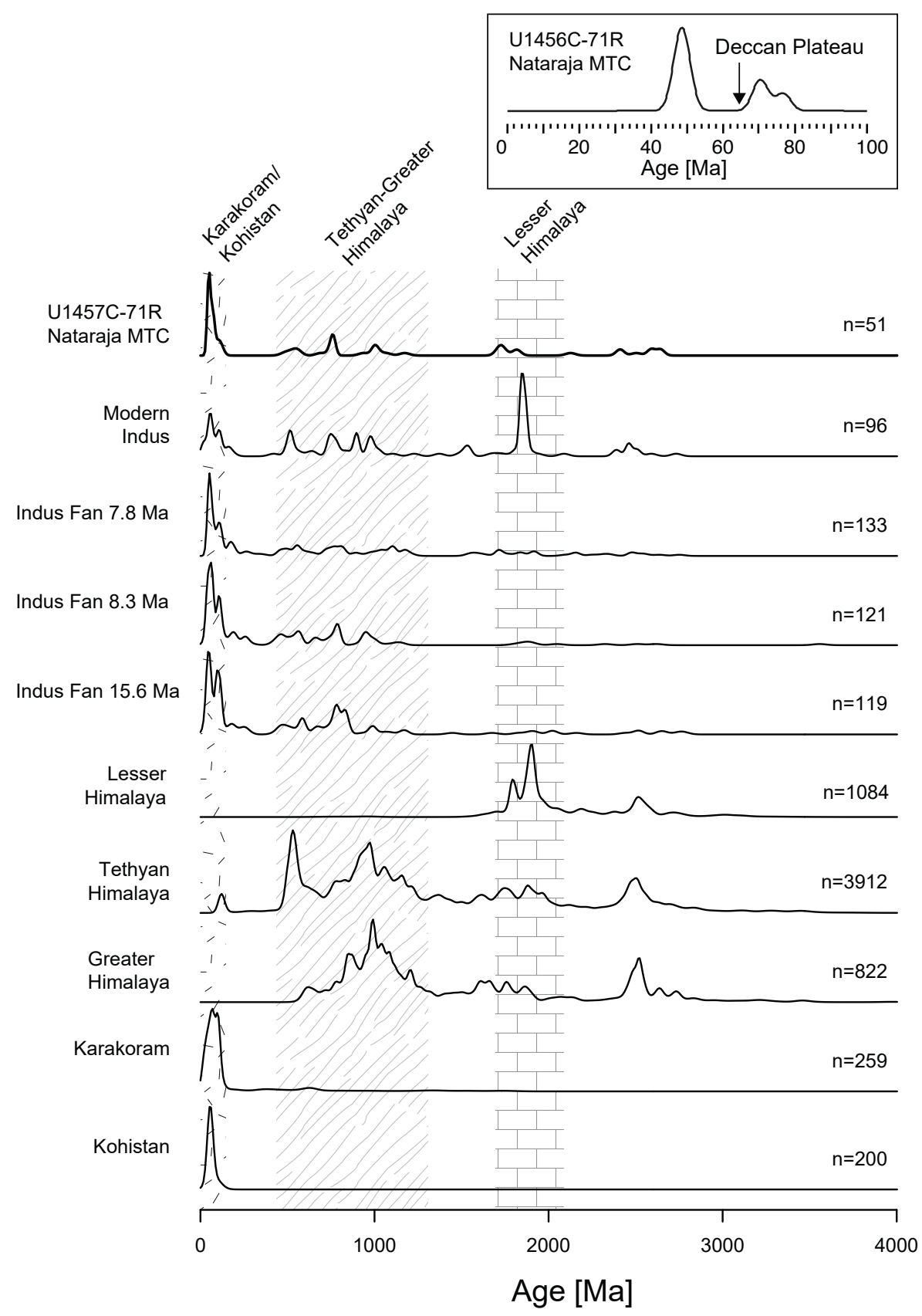

Figure 16

Dailey et al. 


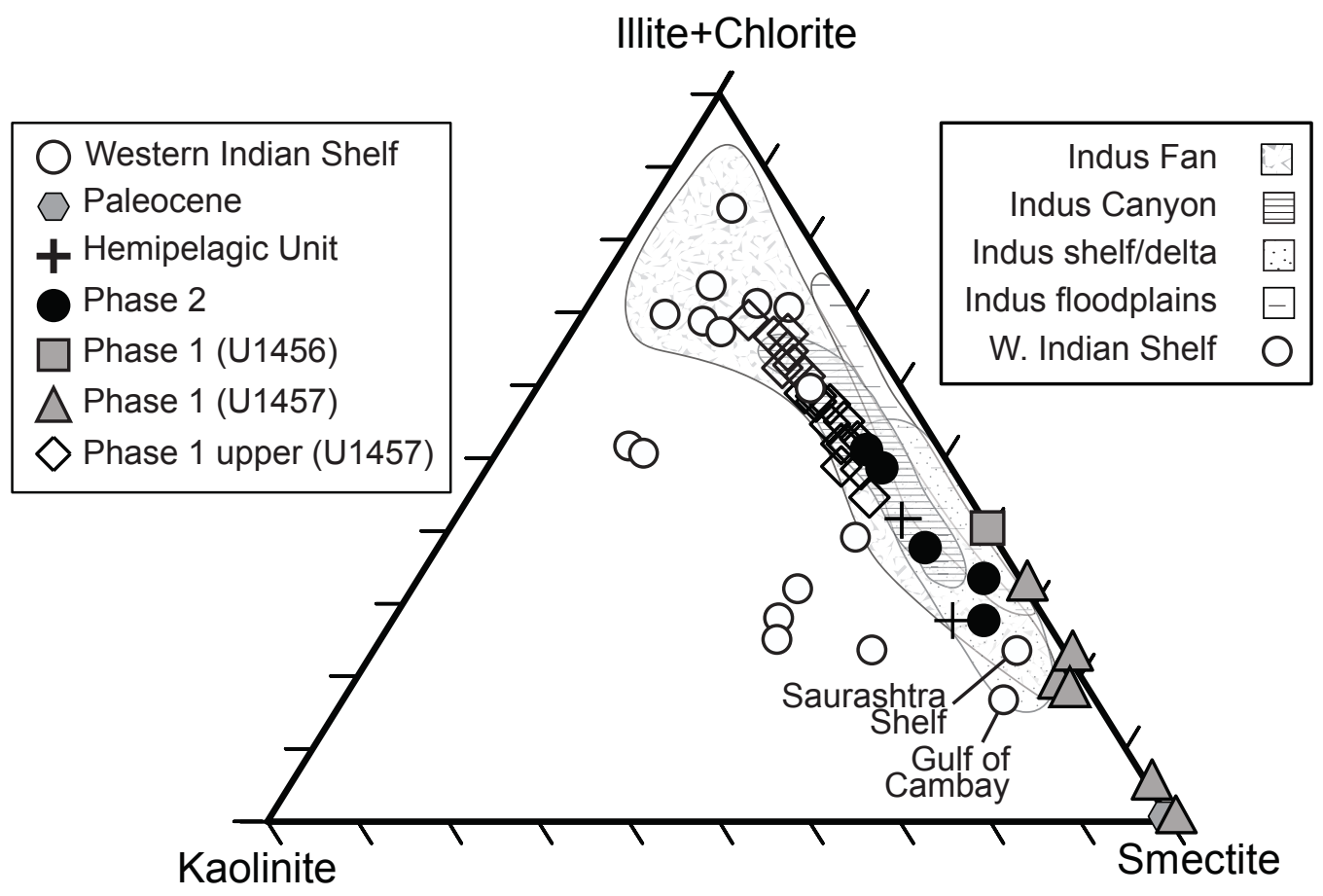

Figure 17

Dailey et al. 

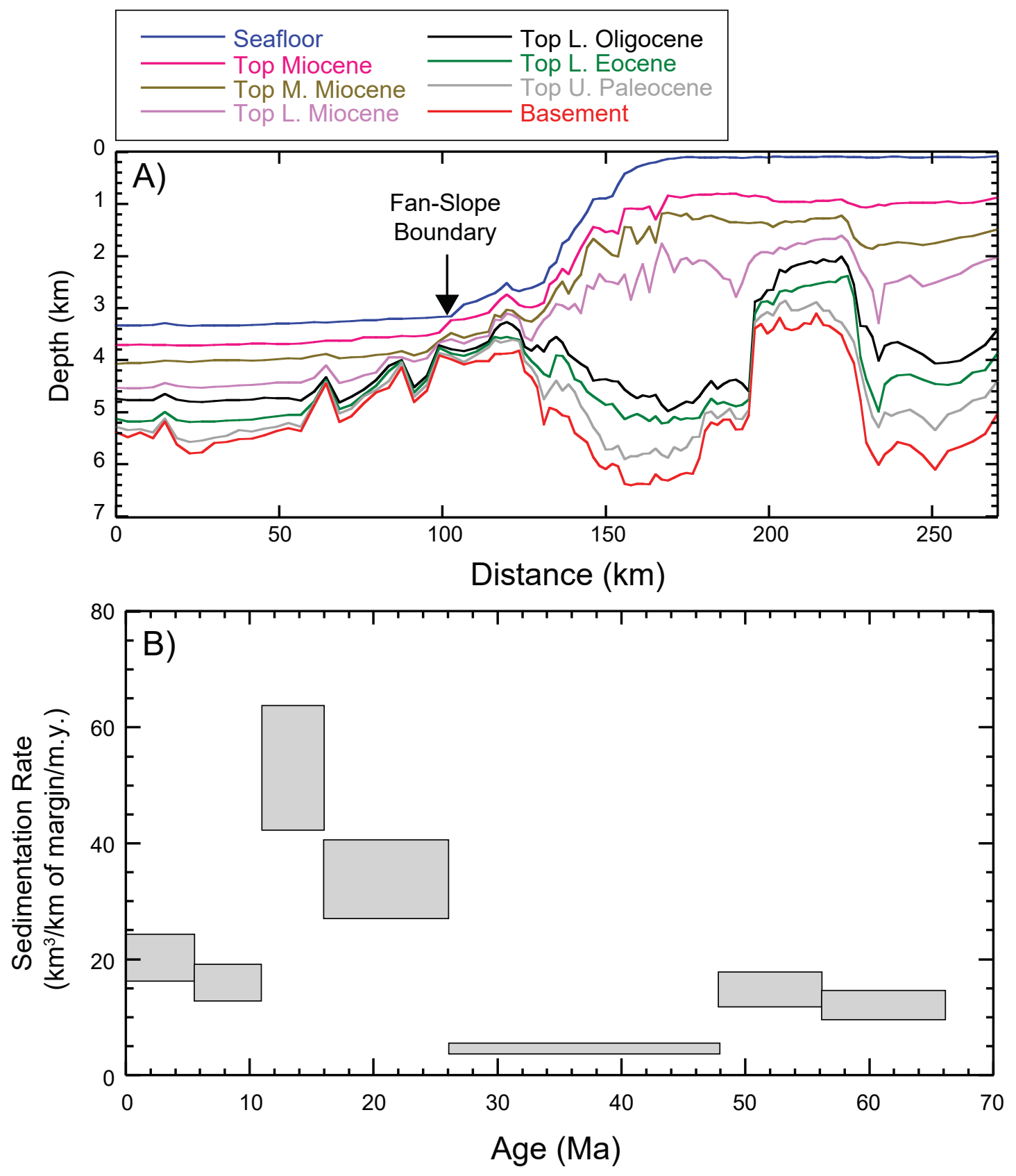

Figure 18

Dailey et al 

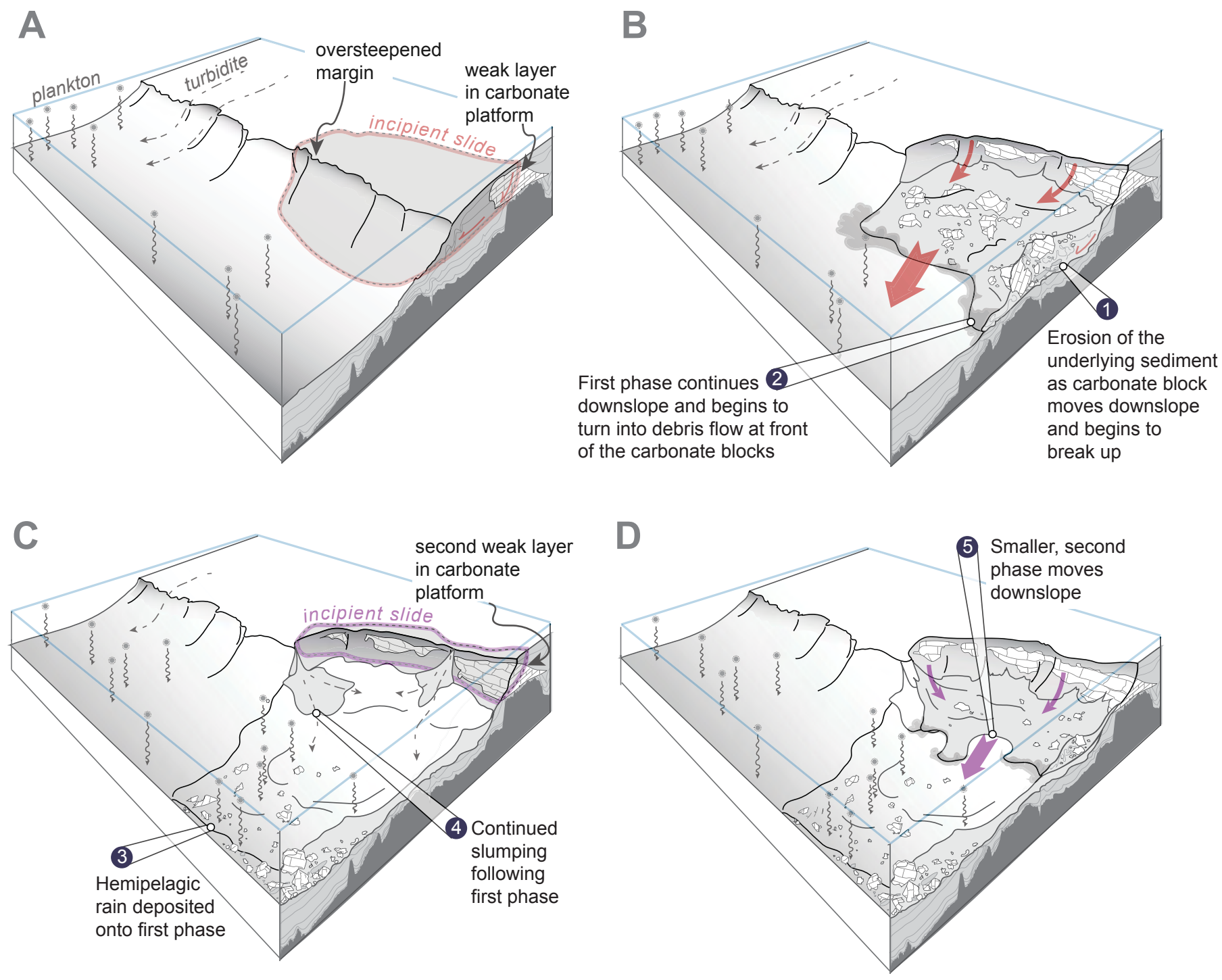

Figure 19

Dailey et al 


\begin{tabular}{|c|c|c|c|c|c|c|c|c|c|c|c|c|c|c|}
\hline Sample & $\begin{array}{l}\text { Depth } \\
\text { (mbsf) }\end{array}$ & $\begin{array}{c}\mathrm{P}_{2} \mathrm{O}_{5} \\
(\%)\end{array}$ & $\begin{array}{c}\mathrm{SiO} 2 \\
(\%)\end{array}$ & $\begin{array}{c}\mathrm{MnO} \\
(\%)\end{array}$ & $\begin{array}{c}\mathrm{Fe}_{2} \mathrm{O}_{3} \\
(\%)\end{array}$ & $\begin{array}{c}\mathrm{MgO} \\
(\%)\end{array}$ & $\begin{array}{c}\mathrm{Al}_{2} \mathrm{O}_{3} \\
(\%)\end{array}$ & $\begin{array}{l}\mathrm{TiO}_{2} \\
(\%)\end{array}$ & $\begin{array}{l}\mathrm{CaO} \\
(\%)\end{array}$ & $\begin{array}{c}\mathrm{Na}_{2} \mathrm{O} \\
(\%)\end{array}$ & $\begin{array}{l}\mathrm{K}_{2} \mathrm{O} \\
(\%) \\
\end{array}$ & $\begin{array}{c}\mathrm{Zr} \\
(\mathrm{ppm})\end{array}$ & $\begin{array}{c}\mathrm{Sr} \\
(\mathrm{ppm})\end{array}$ & $\begin{array}{c}\mathrm{Ba} \\
(\mathrm{ppm})\end{array}$ \\
\hline \multicolumn{15}{|l|}{ IODP U1456D } \\
\hline $35 \mathrm{R}-4,107-122 \mathrm{~cm}$ & 784.47 & 0.18 & 8.71 & 0.09 & 8.98 & 3.75 & 15.80 & 0.98 & 0.32 & 0.15 & 2.87 & 162.01 & 119.59 & 403.54 \\
\hline $38 \mathrm{R}-1,22-24 \mathrm{~cm}$ & 808.00 & 0.12 & 52.99 & 0.04 & 7.93 & 3.33 & 17.12 & 1.12 & 0.19 & 0.40 & 2.98 & 152.43 & 96.48 & 431.06 \\
\hline $42 \mathrm{R}-6,40-42 \mathrm{~cm}$ & 854.30 & 0.13 & 53.39 & 0.05 & 8.56 & 4.15 & 16.21 & 0.97 & 0.18 & 0.69 & 3.34 & 162.15 & 82.60 & 368.68 \\
\hline $46 \mathrm{R}-4,8-10 \mathrm{~cm}$ & 883.40 & 0.12 & 53.59 & 0.04 & 8.33 & 3.17 & 16.77 & 1.44 & 0.27 & 0.64 & 2.90 & 199.20 & 89.80 & 404.49 \\
\hline $49 \mathrm{R}-1,50-52 \mathrm{~cm}$ & 908.00 & 0.12 & 49.57 & 0.06 & 9.50 & 3.01 & 17.18 & 1.51 & 0.54 & 0.38 & 2.72 & 178.69 & 125.28 & 414.05 \\
\hline 52R-5, 65-67 cm & 943.10 & 0.10 & 56.31 & 0.04 & 6.78 & 4.13 & 15.81 & 1.00 & 0.20 & 0.77 & 3.22 & 204.61 & 80.95 & 350.21 \\
\hline $54 \mathrm{R}-1,5-7 \mathrm{~cm}$ & 956.50 & 0.12 & 53.22 & 0.04 & 8.28 & 3.18 & 17.09 & 1.29 & 0.23 & 0.48 & 3.09 & 166.90 & 90.29 & 366.60 \\
\hline $59 \mathrm{R}-5,10-12 \mathrm{~cm}$ & 1002.60 & 0.09 & 54.77 & 0.05 & 7.50 & 3.17 & 11.51 & 0.71 & 1.31 & 0.55 & 2.30 & 171.54 & 738.40 & 2088.35 \\
\hline $60 \mathrm{R}-1,109-111 \mathrm{~cm}$ & 1006.50 & 0.26 & 53.12 & 0.10 & 6.96 & 3.37 & 11.39 & 0.74 & 1.48 & 0.39 & 1.98 & 82.44 & 308.40 & 1806.13 \\
\hline \multicolumn{15}{|l|}{ IODP U1456E } \\
\hline $9 \mathrm{R}-4,64-66 \mathrm{~cm}$ & 1021.00 & 0.04 & 51.60 & 0.07 & 8.54 & 3.43 & 12.40 & 0.89 & 1.63 & 0.15 & 1.56 & 159.79 & 282.36 & 1890.01 \\
\hline $12 \mathrm{R}-1,112-114 \mathrm{~cm}$ & 1044.70 & 0.07 & 51.45 & 0.03 & 8.85 & 3.25 & 12.89 & 0.89 & 1.25 & 0.28 & 1.84 & 181.84 & 108.74 & 736.09 \\
\hline $17 \mathrm{R}-7,42-44 \mathrm{~cm}$ & 1090.10 & 0.06 & 49.46 & 0.05 & 9.64 & 3.26 & 14.60 & 1.05 & 1.21 & 0.20 & 2.17 & 159.60 & 108.94 & 1250.60 \\
\hline \multicolumn{15}{|l|}{ IODP $1457 \mathrm{C}$} \\
\hline $68 \mathrm{R}-7,128-130 \mathrm{~cm}$ & 842.50 & 0.11 & 5.57 & 0.04 & 7.16 & 3 & 16.51 & 1.05 & 0.20 & 0.74 & 2.89 & 168.76 & 66 & 409.00 \\
\hline $4-107 \mathrm{~cm}$ & 846.53 & 0.15 & 53.50 & 0.17 & 7.60 & 4.92 & 15.50 & 0.91 & 1.30 & 0.65 & 2.84 & 176.97 & 100.61 & 30 \\
\hline $69 \mathrm{R}-7,13-16 \mathrm{~cm}$ & 850.38 & 0.12 & 51.61 & 0.08 & 8.59 & 3.55 & 16.02 & 1.02 & 0.65 & 0.50 & 3.09 & 161.96 & 104.08 & 385.13 \\
\hline $70 \mathrm{R}-1,6-8 \mathrm{~cm}$ & 851.70 & 0.12 & 54.35 & 0.04 & 8.05 & 3.18 & 17.25 & 1.22 & 0.43 & 0.56 & 3.20 & 154.32 & 85.26 & 416.50 \\
\hline $70 \mathrm{R}-5,95-98 \mathrm{~cm}$ & 858.16 & 0.34 & 53.30 & 0.29 & 7.90 & 4.85 & 14.87 & 0.86 & 1.05 & 0.67 & 2.84 & 169.51 & 105.17 & 344.01 \\
\hline $71 \mathrm{R}-1,7-9 \mathrm{~cm}$ & 861.50 & 0.12 & 52.49 & 0.04 & 8.26 & 3.36 & 17.39 & 1.20 & 0.30 & 0.37 & 3.12 & 143.35 & 73.07 & 337.56 \\
\hline $71 \mathrm{R}-2,109-111 \mathrm{~cm}$ & 863. & 0.17 & 50.69 & 0.1 & 6.35 & & 13.48 & 0.97 & 7.89 & 0.66 & 2.39 & 191.88 & 03 & 86 \\
\hline $72 \mathrm{R}-1,107-110 \mathrm{~cm}$ & 871.49 & 0.14 & 51.68 & 0.10 & 8.23 & 3.53 & 16.34 & 1.04 & 2.21 & 0.46 & 2.94 & 173.34 & 142.98 & 346.71 \\
\hline $73 \mathrm{R}-1,10-12 \mathrm{~cm}$ & 857.78 & 0.11 & 53.52 & 0.03 & 8.18 & 3.28 & 17.40 & 1.12 & 0.09 & 0.38 & 3.39 & 156.13 & 69.86 & 357.88 \\
\hline $\mathrm{cm}$ & 89175 & 0.12 & 62.72 & 0.03 & 5.73 & 2.76 & 14.14 & 0.96 & 0.50 & 1.00 & 2.67 & 216.07 & 93.56 & 370.40 \\
\hline $75 \mathrm{R}-1,36-40 \mathrm{~cm}$ & 900.06 & 0.15 & 50.12 & 0.20 & 8.51 & 4.00 & 16.01 & 0.98 & 2.34 & 0.28 & 2.91 & 162.80 & 155.71 & 325.69 \\
\hline 76R- 1, 90-92 cm & 911.89 & 0.15 & 58.24 & 0.04 & 7.05 & 3.10 & 16.64 & 1.01 & 0.42 & 0.60 & 2.98 & 183.48 & 83.48 & 333.03 \\
\hline 76R- 3, 44-47 cm & 912.57 & 0.16 & 49.16 & 0.11 & 9.53 & 3.67 & 16.17 & 1.21 & 1.95 & 0.43 & 2.69 & 176.56 & 136.57 & 344.65 \\
\hline $77 \mathrm{R}-2,3-5 \mathrm{~cm}$ & 923.50 & 0.13 & 53.97 & 0.04 & 8.05 & 3.30 & 17.02 & 1.21 & 0.28 & 0.43 & 2.93 & 171.88 & 78.31 & 359.82 \\
\hline $77 \mathrm{R}-5,26-29 \mathrm{~cm}$ & 924.94 & 0.11 & 50.07 & 0.09 & 8.35 & 3.60 & 16.23 & 1.00 & 3.02 & 0.38 & 2.88 & 162.60 & 188.13 & 320.07 \\
\hline $78 \mathrm{R}-4,25-28 \mathrm{~cm}$ & 93328 & 0.14 & 49.34 & 013 & 9.62 & 3.79 & 16.33 & 1.17 & 1.61 & 0.39 & 2.80 & 178.48 & 132.21 & 305.89 \\
\hline $78 \mathrm{R}, 5,50-52 \mathrm{~cm}$ & 933.78 & 0.12 & 56.60 & 0.03 & 6.28 & 3.10 & 15.49 & 1.00 & 0.30 & 0.68 & 2.95 & 182.32 & 81.19 & 325.06 \\
\hline $79 R-5,120-122$ & 945.74 & 0.15 & 58.44 & 0.04 & 7.06 & 3.16 & 16.02 & 1.02 & 0.40 & 0.66 & 3.11 & 215.88 & 81.25 & 298.55 \\
\hline $81 \mathrm{R}-1,30-32 \mathrm{~cm}$ & 958.20 & 0.15 & 53.22 & 0.12 & 7.45 & 3.46 & 14.95 & 0.90 & 3.36 & 0.45 & 2.77 & 179.71 & 157.01 & 270.30 \\
\hline 81R-1, 42-44 cm & 958.32 & 0.15 & 57.32 & 0.05 & 7.19 & 3.34 & 16.27 & 0.97 & 0.42 & 0.62 & 3.15 & 176.67 & 81.33 & 279.34 \\
\hline $82 \mathrm{R}-3,6-9 \mathrm{~cm}$ & 970.66 & 0.15 & 58.78 & 0.13 & 6.10 & 2.96 & 11.45 & 0.73 & 4.59 & 0.93 & 2.13 & 246.76 & 168.04 & 245.10 \\
\hline $82 \mathrm{R}-3,89-91 \mathrm{~cm}$ & 971.55 & 0.17 & 62.47 & 0.04 & 6.40 & 2.99 & 14.53 & 0.96 & 0.62 & 0.95 & 2.88 & 222.25 & 94.57 & 306.87 \\
\hline $83 \mathrm{R}-1,61-63 \mathrm{~cm}$ & 978.00 & 0.10 & 52.09 & 0.03 & 7.98 & 3.13 & 17.49 & 1.25 & 0.16 & 0.35 & 3.06 & 168.56 & 67.93 & 282.34 \\
\hline $84 \mathrm{R}-6,101-103 \mathrm{~cm}$ & 991.90 & 0.14 & 56.77 & 0.06 & 7.12 & 3.88 & 15.83 & 0.90 & 0.28 & 0.69 & 3.31 & 185.01 & 78.23 & 266.53 \\
\hline $85 \mathrm{R}-1,60-62 \mathrm{~cm}$ & 998.40 & 0.12 & 57.92 & 0.05 & 7.09 & 3.98 & 16.02 & 0.92 & 0.29 & 0.71 & 3.36 & 184.78 & 82.51 & 274.00 \\
\hline $85 \mathrm{R}-3,46-49 \mathrm{~cm}$ & 999.74 & 0.16 & 53.58 & 0.15 & 7.86 & 4.65 & 15.32 & 0.89 & 0.99 & 0.72 & 3.21 & 185.22 & 116.33 & 261.00 \\
\hline $86 \mathrm{R}-2,44-47 \mathrm{~cm}$ & 1008.04 & 0.11 & 18.69 & 0.07 & 2.73 & 1.75 & 6.14 & 0.31 & 31.32 & 0.07 & 0.95 & 57.03 & 720.11 & 611.45 \\
\hline $87 \mathrm{R}-1,14-18 \mathrm{~cm}$ & 1011.22 & 0.10 & 15.76 & 0.07 & 2.11 & 1.45 & 5.20 & 0.24 & 32.94 & 0.08 & 0.71 & 47.83 & 649.62 & 1357.92 \\
\hline $89 \mathrm{R}-2,57-59 \mathrm{~cm}$ & 1027.62 & 0.08 & 52.64 & 0.06 & 8.63 & 3.41 & 11.45 & 0.76 & 1.93 & 0.26 & 1.63 & 94.10 & 222.78 & 1315.27 \\
\hline $89 \mathrm{R}-3,119-121 \mathrm{~cm}$ & 1029.30 & 0.05 & 52.31 & 0.03 & 7.46 & 4.03 & 13.01 & 0.77 & 0.90 & 0.43 & 2.41 & 138.94 & 82.01 & 308.97 \\
\hline $96 \mathrm{R}-1,62-66 \mathrm{~cm}$ & 1090.74 & 0.09 & 47.67 & 1.10 & 10.46 & 3.37 & 12.29 & 0.95 & 0.92 & 0.49 & 2.22 & 139.86 & 113.58 & 102.65 \\
\hline
\end{tabular}


Table 2

\begin{tabular}{|c|c|c|c|}
\hline Sample & ${ }^{87} \mathrm{Sr} /{ }^{86} \mathrm{Sr}$ & ${ }^{143} \mathrm{Nd} /{ }^{144} \mathrm{Nd}$ & Epsilon $\mathrm{Nd}$ \\
\hline \multicolumn{4}{|l|}{ IODP U1456D } \\
\hline $35 \mathrm{R}-4,107-122 \mathrm{~cm}$ & 0.718548 & 0.512186 & -8.8 \\
\hline $38 \mathrm{R}-1,22-24 \mathrm{~cm}$ & 0.719026 & 0.512219 & -8.2 \\
\hline $42 \mathrm{R}-6,40-42 \mathrm{~cm}$ & 0.716960 & 0.512233 & -7.9 \\
\hline $46 \mathrm{R}-4,8-10 \mathrm{~cm}$ & 0.717475 & 0.512210 & -8.3 \\
\hline $49 \mathrm{R}-1,50-52 \mathrm{~cm}$ & 0.718123 & 0.512200 & -8.5 \\
\hline $52 \mathrm{R}-5,65-67 \mathrm{~cm}$ & 0.717166 & 0.512191 & -8.7 \\
\hline $54 \mathrm{R}-1,5-7 \mathrm{~cm}$ & 0.720084 & 0.512137 & -9.8 \\
\hline $59 \mathrm{R}-5,10-12 \mathrm{~cm}$ & 0.708516 & 0.512560 & -1.5 \\
\hline \multicolumn{4}{|l|}{ IODP U1456E } \\
\hline $12 \mathrm{R}-1,112-114 \mathrm{~cm}$ & 0.713705 & 0.512251 & -7.5 \\
\hline $17 \mathrm{R}-7,42-44 \mathrm{~cm}$ & 0.715006 & 0.512184 & -8.9 \\
\hline 19R-CC, $17-22 \mathrm{~cm}$ & 0.725510 & 0.512193 & -8.7 \\
\hline \multicolumn{4}{|l|}{ IODP $1457 \mathrm{C}$} \\
\hline $68 \mathrm{R}-7,128-130 \mathrm{~cm}$ & 0.717787 & 0.512169 & -9.1 \\
\hline 69R-1, 100-104 cm & 0.713055 & 0.512187 & -8.8 \\
\hline $69 \mathrm{R}-5,136-148 \mathrm{~cm}$ & 0.717709 & 0.512196 & -8.6 \\
\hline $70 \mathrm{R}-4,137-152 \mathrm{~cm}$ & 0.717619 & 0.512197 & -8.6 \\
\hline $70 \mathrm{R}-5,95-97 \mathrm{~cm}$ & 0.712897 & 0.512305 & -6.5 \\
\hline $71 \mathrm{R}-6,18-28 \mathrm{~cm}$ & 0.719332 & 0.512147 & -9.6 \\
\hline $74 \mathrm{R}-2,19-21 \mathrm{~cm}$ & 0.718539 & 0.512119 & -10.1 \\
\hline $75 \mathrm{R}-1,36-40 \mathrm{~cm}$ & 0.712895 & 0.512207 & -8.4 \\
\hline $78 \mathrm{R}, 5,50-52 \mathrm{~cm}$ & 0.719460 & 0.512089 & -10.7 \\
\hline $81 \mathrm{R}-1,30-32 \mathrm{~cm}$ & 0.713224 & 0.512169 & -9.1 \\
\hline $83 \mathrm{R}-1,61-63 \mathrm{~cm}$ & 0.721653 & 0.512128 & -9.9 \\
\hline $87 \mathrm{R}-1,14-18 \mathrm{~cm}$ & 0.708510 & 0.512357 & -5.5 \\
\hline $89 \mathrm{R}-3,119-121 \mathrm{~cm}$ & 0.716107 & 0.512198 & -8.6 \\
\hline $96 \mathrm{R}-1,62-66 \mathrm{~cm}$ & 0.709144 & 0.512348 & -5.7 \\
\hline
\end{tabular}

Dailey et al. 
Table 3

\begin{tabular}{|c|c|c|c|c|c|c|c|c|c|c|c|c|c|c|c|}
\hline Sample & Facies & 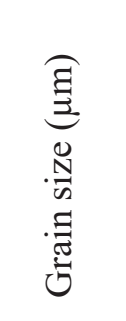 & 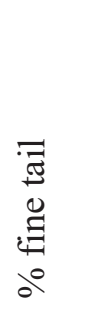 & 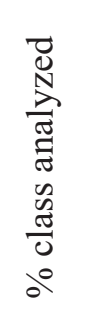 & 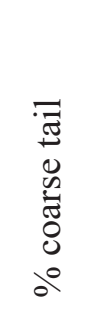 & 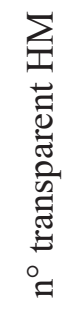 & 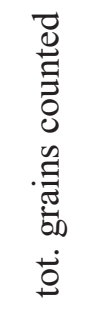 & 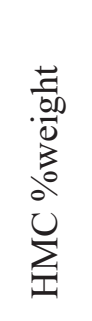 & $\begin{array}{l}\vec{E} \\
\frac{\overrightarrow{b 0}}{0} \\
3 \\
\sum^{0} \\
\stackrel{0}{0}\end{array}$ & 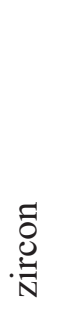 & 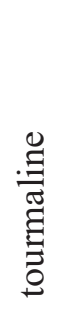 & $\stackrel{\stackrel{\theta}{\Xi}}{\stackrel{\Xi}{\Xi}}$ & 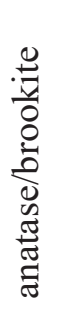 & 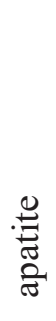 & .气 \\
\hline Tapti River & Sand bar & $15-500$ & $15 \%$ & $78 \%$ & $7 \%$ & 215 & 309 & 24 & 17 & 0 & 0 & 0 & 0 & 0 & 1 \\
\hline 1456E-4R-1, $110 \mathrm{~cm}$ & Packstone & $15-500$ & $63 \%$ & $37 \%$ & $0.1 \%$ & 209 & 3336 & 0.08 & 0.02 & 5 & 13 & 2 & 1 & 24 & 10 \\
\hline 1456E-7R-1, $80 \mathrm{~cm}$ & Packstone & $15-500$ & $46 \%$ & $54 \%$ & $0.2 \%$ & 21 & 1449 & 0.06 & 0.00 & 5 & 5 & 0 & 0 & 10 & 5 \\
\hline 1456E-15R-1, $61 \mathrm{~cm}$ & Breccia & $15-500$ & $52 \%$ & $33 \%$ & $15 \%$ & 68 & 2557 & 0.04 & 0.00 & 10 & 4 & 1 & 0 & 16 & 13 \\
\hline 1456E-17R-4, $131 \mathrm{~cm}$ & Breccia & $15-500$ & $50 \%$ & $24 \%$ & $26 \%$ & 64 & 1144 & 0.05 & 0.01 & 6 & 6 & 3 & 0 & 22 & 8 \\
\hline $1457 \mathrm{C}-88 \mathrm{R}-4,58 \mathrm{~cm}$ & Packstone & $15-500$ & $42 \%$ & $53 \%$ & $5 \%$ & 216 & 819 & 0.14 & 0.08 & 4 & 6 & 1 & 1 & 11 & 9 \\
\hline & 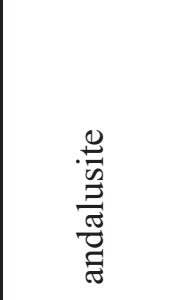 & 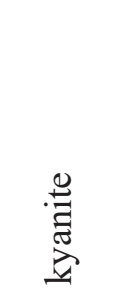 & 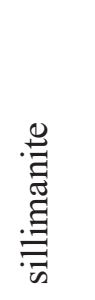 & 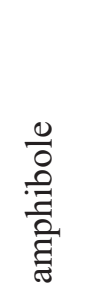 & 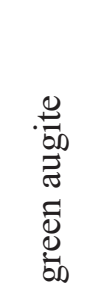 & 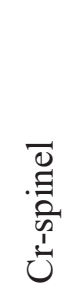 & 吾 & $\frac{\widetilde{v}}{N}$ & 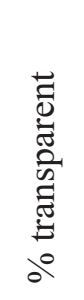 & 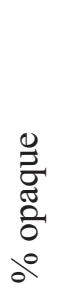 & $\begin{array}{l}\frac{0}{0} \\
0 \\
0 \\
0 \\
0 \\
0 \\
0\end{array}$ & 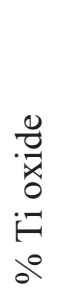 & 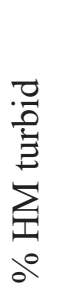 & 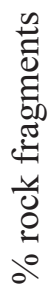 & 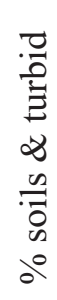 \\
\hline Tapti River & 0 & 0 & 1 & 2 & 92 & 0.0 & 4.7 & 0 & 70 & 24 & 4 & 0 & 0 & 1 & 0 \\
\hline 1456E-4R-1, $110 \mathrm{~cm}$ & 0.5 & 2 & 0 & 2 & 1 & $T$ & 90.4 & 20 & 6 & 8 & 7 & 1 & 0 & 0 & 0 \\
\hline $1456 \mathrm{E}-7 \mathrm{R}-1,80 \mathrm{~cm}$ & 0 & 0 & 0 & 10 & 48 & 0 & 42.9 & 10 & 1 & 61 & 0 & 0 & 0 & 0 & 0 \\
\hline 1456E-15R-1, $61 \mathrm{~cm}$ & 3 & 1 & 0 & 0 & 6 & 3 & 86.8 & 16 & 3 & 19 & 5 & 0 & 0 & 0 & 0 \\
\hline $1456 \mathrm{E}-17 \mathrm{R}-4,131 \mathrm{~cm}$ & 0 & 0 & 0 & 3 & 6 & 2 & 89.1 & 16 & 6 & 10 & 7 & 0 & 0 & 0 & 0 \\
\hline $1457 \mathrm{C}-88 \mathrm{R}-4,58 \mathrm{~cm}$ & 0.5 & 1 & 0 & 8 & 1 & 2 & 87.5 & 11 & 26 & 11 & 5 & 1 & 0 & 0 & 0 \\
\hline
\end{tabular}

Dailey et al. 
Table 3

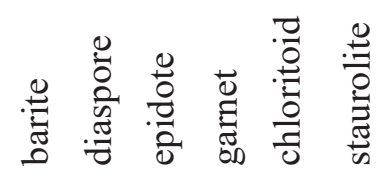

\begin{tabular}{cccccc}
\hline 0 & 0 & 2 & 1 & 0 & 0 \\
3 & 0 & 9 & 15 & 8 & 1 \\
5 & 0 & 0 & 14 & 0 & 0 \\
4 & 0 & 9 & 21 & 3 & 4 \\
5 & 0 & 9 & 25 & 3 & 2 \\
3 & 0.5 & 30 & 18 & 4 & 0.5
\end{tabular}

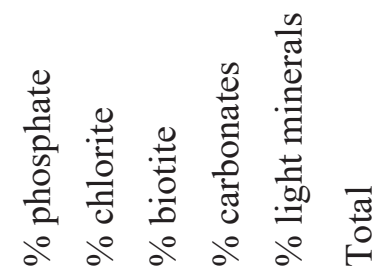

\begin{tabular}{llllll}
\hline 0 & 0 & 0 & 0 & 1 & 100
\end{tabular}

$\begin{array}{llllll}35 & 6 & 6 & 30 & 1 & 100\end{array}$

$\begin{array}{llllll}17 & 0 & 1 & 19 & 0 & 100\end{array}$

$\begin{array}{llllll}57 & 1 & 1 & 13 & 1 & 100\end{array}$

$\begin{array}{llllll}59 & 1 & 3 & 10 & 3 & 100\end{array}$

$\begin{array}{llllll}19 & 6 & 12 & 15 & 5 & 100\end{array}$

Dailey et al. 


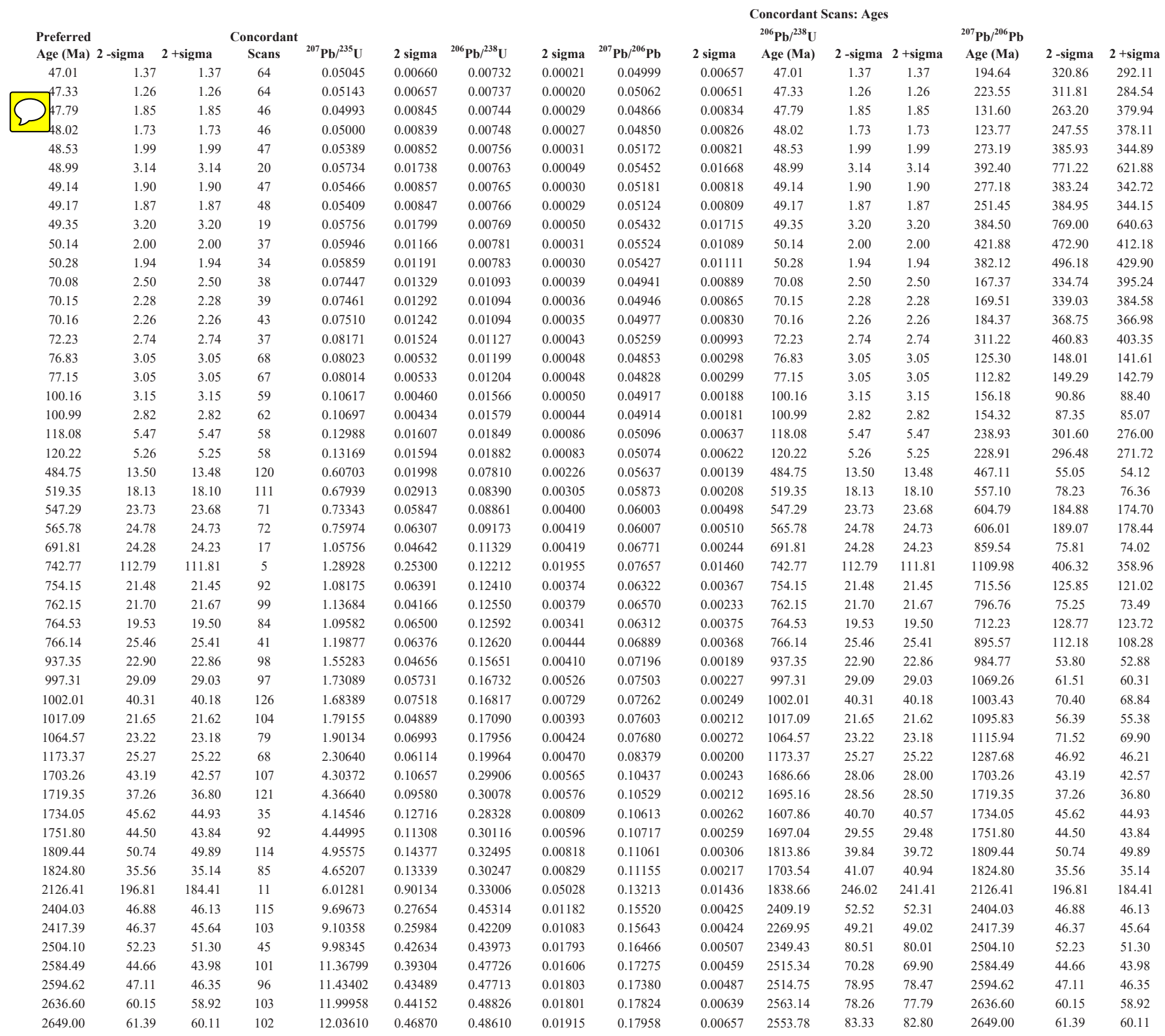


Table 5

Smectite Chlorite Illite Kaolinite Palygorskite

\begin{tabular}{|c|c|c|c|c|c|}
\hline Sample & $(\%)$ & $(\%)$ & $(\%)$ & $(\%)$ & $(\%)$ \\
\hline \multicolumn{6}{|l|}{ IODP U1456D } \\
\hline $35 \mathrm{R}-4,107-122 \mathrm{~cm}$ & 37.6 & 18.7 & 33.0 & 9.6 & 0.0 \\
\hline $39 \mathrm{R}-1,12-14 \mathrm{~cm}$ & 40.9 & 13.8 & 36.8 & 8.2 & 0.0 \\
\hline $40 \mathrm{R}-1,60-62 \mathrm{~cm}$ & 43.1 & 13.9 & 8.0 & 8.1 & 34.1 \\
\hline $43 \mathrm{R}-7,2-4 \mathrm{~cm}$ & 62.2 & 12.9 & 19.9 & 4.4 & 0.0 \\
\hline $47 \mathrm{R}-4,58-60 \mathrm{~cm}$ & 65.2 & 13.8 & 13.4 & 7.3 & 0.0 \\
\hline $50 \mathrm{R}-1,31-33 \mathrm{~cm}$ & 53.8 & 15.5 & 21.9 & 8.5 & 0.0 \\
\hline $51 \mathrm{R}-6,20-22 \mathrm{~cm}$ & 61.4 & 11.9 & 15.8 & 10.0 & 0.0 \\
\hline $53 \mathrm{R}-1,5-7 \mathrm{~cm}$ & 49.1 & 14.6 & 27.0 & 8.7 & 0.0 \\
\hline $57 \mathrm{R}-7,75-77 \mathrm{~cm}$ & 53.1 & 8.4 & 26.5 & 0.0 & 10.6 \\
\hline $58 \mathrm{R}-2,2-4 \mathrm{~cm}$ & 69.9 & 3.8 & 17.5 & 0.0 & 6.7 \\
\hline $61 \mathrm{R}-1,40-42 \mathrm{~cm}$ & 91.9 & 0.8 & 4.8 & 0.0 & 2.5 \\
\hline \multicolumn{6}{|l|}{ IODP U1456E } \\
\hline $5 \mathrm{R}-2,25-27 \mathrm{~cm}$ & 100.0 & 0.0 & 0.0 & 0.0 & 0.0 \\
\hline $14 \mathrm{R}-1,75-77 \mathrm{~cm}$ & 96.9 & 0.0 & 0.0 & 0.0 & 0.0 \\
\hline $16 \mathrm{R}-2,5-7 \mathrm{~cm}$ & 54.8 & 4.6 & 22.5 & 0.0 & 18.0 \\
\hline 19R-CC, $17-22 \mathrm{~cm}$ & 40.0 & 25.0 & 28.3 & 5.1 & 0.0 \\
\hline \multicolumn{6}{|l|}{ IODP U1457C } \\
\hline $69 \mathrm{R}-4,104-106 \mathrm{~cm}$ & 17.2 & 27.2 & 33.5 & 10.9 & 9.9 \\
\hline $69 \mathrm{R}-6,13-15 \mathrm{~cm}$ & 23.2 & 26.7 & 35.6 & 8.2 & 4.8 \\
\hline $69 \mathrm{R}-7,112-114 \mathrm{~cm}$ & 29.0 & 22.6 & 37.4 & 9.7 & 0.0 \\
\hline $70 \mathrm{R}-5,95-97 \mathrm{~cm}$ & 32.3 & 18.8 & 30.6 & 9.6 & 7.6 \\
\hline $71 \mathrm{R}-2,109-111 \mathrm{~cm}$ & 38.5 & 17.9 & 33.2 & 9.7 & 0.0 \\
\hline 72R-1, 107-109 cm & 30.3 & 23.2 & 34.2 & 10.8 & 0.0 \\
\hline $74 \mathrm{R}-2,25-27 \mathrm{~cm}$ & 31.8 & 23.1 & 33.2 & 10.3 & 0.0 \\
\hline $75 \mathrm{R}-1,36-40 \mathrm{~cm}$ & 36.2 & 21.0 & 33.0 & 8.4 & 0.0 \\
\hline $76 \mathrm{R}-3,44-46 \mathrm{~cm}$ & 44.3 & 17.9 & 25.8 & 11.2 & 0.0 \\
\hline $77 \mathrm{R}-5,26-28 \mathrm{~cm}$ & 41.3 & 19.2 & 28.5 & 10.1 & 0.0 \\
\hline $78 \mathrm{R}-4,25-27 \mathrm{~cm}$ & 39.1 & 19.9 & 28.1 & 11.9 & 0.0 \\
\hline $79 \mathrm{R}-5,129-131 \mathrm{~cm}$ & 26.2 & 23.1 & 37.9 & 11.7 & 0.0 \\
\hline $81 \mathrm{R}-1,30-32 \mathrm{~cm}$ & 27.1 & 22.2 & 39.3 & 10.4 & 0.0 \\
\hline $82 \mathrm{R}-3,6-8 \mathrm{~cm}$ & 25.5 & 20.9 & 42.6 & 10.2 & 0.0 \\
\hline $83 \mathrm{R}-2,18-20 \mathrm{~cm}$ & 37.7 & 16.8 & 34.1 & 10.4 & 0.0 \\
\hline $84 \mathrm{R}-3,143-145 \mathrm{~cm}$ & 23.1 & 25.0 & 39.9 & 10.4 & 0.0 \\
\hline $85 \mathrm{R}-3,46-48 \mathrm{~cm}$ & 31.1 & 15.8 & 36.2 & 8.1 & 8.1 \\
\hline $86 \mathrm{R}-1,6-8 \mathrm{~cm}$ & 29.6 & 18.2 & 35.3 & 9.1 & 6.9 \\
\hline $86 \mathrm{R}-2,44-46 \mathrm{~cm}$ & 75.5 & 5.1 & 14.4 & 3.1 & 1.5 \\
\hline $87 \mathrm{R}-1,14-18 \mathrm{~cm}$ & 77.0 & 4.5 & 13.6 & 2.6 & 1.5 \\
\hline 93R-1, 50-52 cm & 100.0 & 0.0 & 0.0 & 0.0 & 0.0 \\
\hline $93 \mathrm{R}-3,50-52 \mathrm{~cm}$ & 100.0 & 0.0 & 0.0 & 0.0 & 0.0 \\
\hline $94 \mathrm{R}-2,55-57 \mathrm{~cm}$ & 100.0 & 0.0 & 0.0 & 0.0 & 0.0 \\
\hline $95 \mathrm{R}-1,12-14 \mathrm{~cm}$ & 100.0 & 0.0 & 0.0 & 0.0 & 0.0 \\
\hline
\end{tabular}

Dailey et al. 
Table 5

96R-1, 62-66 cm

100.0

0.0

0.0

0.0

0.0

Dailey et al. 
Table 6

\begin{tabular}{lcc}
$\begin{array}{l}\text { Stratigraphic } \\
\text { interval }\end{array}$ & $\begin{array}{c}\text { Age at base of } \\
\text { interval }\end{array}$ & $\begin{array}{c}\text { Interval velocity } \\
(\mathrm{km} / \mathrm{s})\end{array}$ \\
\hline H7 & Top Miocene & 1.70 \\
H6 & Top M. Miocene & 2.20 \\
H5 & Top L. Miocene & 2.40 \\
H4 & Top. L. Oligocene & 2.45 \\
H3 & Top. L. Eocene & 2.50 \\
H2 & Top U. Paleocene & 2.60 \\
H1 & Basement (66 Ma) & 2.65
\end{tabular}

Dailey et al. 